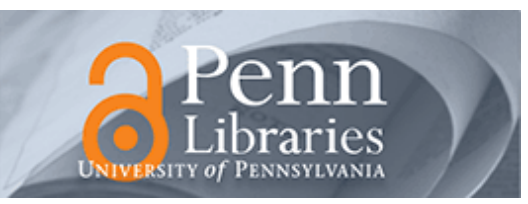

University of Pennsylvania

ScholarlyCommons

\title{
Maternal Undernutrition in Adolescence and Child Human Capital Formation over the Life-Course: Evidence from an International Cohort Study
}

\author{
Andreas Georgiadis \\ Brunel University London - Business School, andreas.georgiadis@brunel.ac.uk \\ Liza Benny \\ University of Essex, I.benny@essex.ac.uk \\ Paul Dornan \\ Jere R. Behrman \\ University of Pennsylvania, jbehrman@sas.upenn.edu
}

Follow this and additional works at: https://repository.upenn.edu/psc_publications

Part of the Demography, Population, and Ecology Commons, Family, Life Course, and Society Commons, Gender and Sexuality Commons, and the Inequality and Stratification Commons

\section{Recommended Citation}

Georgiadis, Andreas, Liza Benny, Paul Dornan, and Jere Behrman. 2021. "Maternal Undernutrition in Adolescence and Child Human Capital Formation over the Life-Course: Evidence from an International Cohort Study." University of Pennsylvania Population Center Working Paper (PSC/PARC), 2021-62. https://repository.upenn.edu/psc_publications/62.

This paper is posted at ScholarlyCommons. https://repository.upenn.edu/psc_publications/62

For more information, please contact repository@pobox.upenn.edu. 


\title{
Maternal Undernutrition in Adolescence and Child Human Capital Formation over the Life-Course: Evidence from an International Cohort Study
}

\author{
Abstract \\ Adolescence has been highlighted as a period when environments are critical for the human capital \\ development of women, and thus of their children, but evidence on this from low- and middle-income \\ countries is scarce. We estimate the effect of mother adolescent undernutrition on offspring growth and \\ development from infancy through adolescence using data from Ethiopia, India, Peru, and Vietnam and \\ Instrumental Variables (IV) estimation that employs rainfall shocks during mother's adolescence as \\ instruments for mother's nutritional status. We find a positive and significant effect of mother adolescent \\ nutritional status on child height-for-age in infancy that persists through to adolescence and evidence \\ that this may manifest mainly through a biological channel. Our results also support a significant impact \\ of rainfall shocks during mother's early adolescence on mother's adult height and child growth from \\ infancy to adolescence. We find no significant effect of mother's adolescent nutritional status and rainfall \\ shocks during mother's adolescence on child achievement tests scores, however.

\section{Keywords} \\ adolescent undernutrition, maternal and child growth, child cognitive

\section{Disciplines} \\ Demography, Population, and Ecology | Family, Life Course, and Society | Gender and Sexuality | Inequality \\ and Stratification | Social and Behavioral Sciences | Sociology
}


Maternal Undernutrition in Adolescence and Child Human Capital Formation over the LifeCourse: Evidence from an International Cohort Study

Andreas Georgiadis, Liza Benny, Paul Dornan, and Jere Behrman

\begin{abstract}
Adolescence has been highlighted as a period when environments are critical for the human capital development of women, and thus of their children, but evidence on this from low- and middle-income countries is scarce. We estimate the effect of mother adolescent undernutrition on offspring growth and development from infancy through adolescence using data from Ethiopia, India, Peru, and Vietnam and Instrumental Variables (IV) estimation that employs rainfall shocks during mother's adolescence as instruments for mother's nutritional status. We find a positive and significant effect of mother adolescent nutritional status on child height-forage in infancy that persists through to adolescence and evidence that this may manifest mainly through a biological channel. Our results also support a significant impact of rainfall shocks during mother's early adolescence on mother's adult height and child growth from infancy to adolescence. We find no significant effect of mother's adolescent nutritional status and rainfall shocks during mother's adolescence on child achievement tests scores, however.
\end{abstract}

Key words: Adolescent undernutrition, maternal and child growth, child cognitive development, rainfall shocks

JEL Classification: I15, J13, 015 


\section{INTRODUCTION}

Economic literature on the process of human capital formation through the life cycle highlights the existence of critical and sensitive periods when investments and environments are particularly effective in fostering the acquisition of skills (Cunha and Heckman, 2007; Heckman, 2007). The identification of these periods is therefore important for the design of interventions that promote human capital. Although early life has been highlighted as a critical period for the development of human capital, relatively little is still known on the extent to which compensation at a later stage of life can remedy earlier deficits (Rutter, 1998; Almond and Currie, 2011).

In low- and middle-income countries (LMICs) child undernutrition, usually indicated by poor growth also known as stunting, is very prevalent and is considered as one of the major threats to human capital development (Grantham-McGregor et al., 2007; Prendergast and Humphrey, 2014). Studies from both the biomedical and economics literatures suggest that growth failure is largely determined during the first 1000 days since conception with limited potential for catch-up growth thereafter. This leads to an intergenerational cycle of poor growth and development, where women who were stunted in childhood remain stunted as adults and tend to have stunted offspring (Martorell and Zogrone, 2012; Currie and Vogl, 2013).

Some have argued that adolescence, a period when growth velocity is high, presents an opportunity for catch-up growth and remediation of early nutritional deficits, particularly for girls (Case and Paxson, 2008; Georgiadis and Penny, 2017). Although there is some supporting evidence (Steckel, 1987; Prentice et al., 2013), this claim is not yet well-established (Van den Berg et al., 2014; Das et al., 2017), and little is known about the long-run and intergenerational implications of maternal nutrition during adolescence (Akresh et al., 2012, 2017).

This is important as in LMICs undernutrition in adolescence is one of the most prevalent and primary risks to the survival, health, and development of young women (WHO, 2012; Das 
et al., 2017) with potential implications for the growth and development of the next generation (Black et al., 2013). Moreover, existing studies have the following limitations: firstly, they produce evidence on the implications for offspring's health outcomes, but not for offspring's cognitive development; secondly, they do not produce evidence on the extent to which impacts persist over the offspring's life courses, which is important to understand the extent to which the responsiveness of child outcomes to interventions is constrained by earlier maternal circumstances (Martorell and Zongrone, 2012); and thirdly, they document correlations between maternal undernutrition and child outcomes - and not causal effects - that cannot produce clear implications for policy.

This paper addresses these limitations and makes three contributions to the existing literature. Our first contribution is that we estimate the effect of maternal undernutrition in adolescence on offspring growth and cognitive achievement from infancy to adolescence using data from an international cohort study in Ethiopia, India, Peru, and Vietnam. Our empirical strategy addresses bias in estimation arising from the endogeneity of mother's nutritional status through Instrumental Variables (IV) employing rainfall shocks during mother's adolescence as instruments for mother's adolescent nutritional status. To our knowledge, this the first study identifying the effects of maternal undernutrition in adolescence on different dimensions of the offspring's human capital, including health and cognitive skills, and how these evolve over the offspring's life course from early childhood through middle adolescence.

Our second contribution is that we investigate potential channels through which the effect of maternal adolescent undernutrition on child growth and development manifests. Finally, our third contribution is that we examine the impact of rainfall shocks during the mother's adolescent years on maternal adult height and child growth and cognitive achievement from infancy to middle adolescence. This allows us to provide additional new evidence of the longrun and inter-generational impacts of environmental insults during adolescence, an area that 
has received little attention in the literature, as existing studies focus on the impacts of shocks during early childhood (Maccini and Yang, 2009; Currie and Vogl, 2013).

We find a positive and significant effect of maternal adolescent nutritional status, as measured by height, on child nutritional status at age 1 year that persists through to age 15 years. Our analysis further suggests that this effect may operate primarily through a biological channel, reflecting a direct intergenerational transmission of undernutrition, and persists mainly because child growth in early years strongly predicts growth in subsequent years. We also find a significant negative effect of rainfall shocks during the period mothers were between 12 and 13 years old on maternal adult height across countries. This could be explained by the fact that higher rainfall is associated with an increase in the prevalence of infectious diseases; this reduces absorption of nutrients by the body at a period that may coincide with the timing of peak height velocity during the pubertal growth spurt in low-income settings (Eckert et al., 2009; Das et al., 2017). Moreover, we find that these shocks have a negative and significant effect on child nutritional status over the life course, particularly in Peru and Vietnam. Our analysis also suggests that this effect does not manifest through altering parental investments or socioeconomic status and operates through early child growth. Nevertheless, we do not find a significant effect of maternal nutritional status and rainfall shocks during mother's early adolescence on child cognitive achievement test scores.

Overall, our findings have important policy implications and suggest that interventions that aim to improve the nutritional status of girls during early adolescence may contribute to breaking the intergenerational cycle of undernutrition in low- and middle-income countries.

The remainder of the paper is organised as follows: Section I presents our empirical strategy; Section II discusses the data and presents descriptive statistics of the variables used in our analysis; Section III presents the estimation results; and Section IV concludes. 


\section{EMPIRICAL MODEL AND ESTIMATION STRATEGY}

We estimate the effect of maternal undernutrition in adolescence on child human capital outcomes at different ages from infancy to adolescence using the following specification:

$$
H C_{i a}=\beta_{0}+\beta_{1} M N_{i}+\boldsymbol{\beta}_{2}^{\prime} \boldsymbol{C} \boldsymbol{H}_{\boldsymbol{i}}+\alpha_{i}+\varepsilon_{i a}
$$

where $H C_{i a}$ is a measure of child $i$ 's human capital at age $a$, i.e., nutritional status, measured by child's height-for-age Z-score, or cognitive achievement, measured by an achievement test score; $M N_{i}$ stands for child $i$ 's maternal nutritional status in adolescence; $\boldsymbol{C H}_{\boldsymbol{i}}$ denotes a vector of maternal characteristics and other factors influencing child human capital that are determined prior to mother's adolescence; $\alpha_{i}$ denotes unobserved child-specific time-invariant factors; and $\varepsilon_{i a}$ is an error capturing the influence of unobserved factors that vary with child's age on child's human capital.

Equation (1) is a conditional demand for child human capital, where conditioning is on mother's adolescent nutritional status that is endogenous in the decision-making problem (Glewwe and Miguel, 2008; Georgiadis, 2017). ${ }^{1}$ Following Glewwe and Miguel (2008), equation (1) can be used to estimate the total effect of mother's nutritional status in adolescence on child human capital. This reflects a direct (biological) effect, manifesting through the child human capital production function and an indirect (behavioural) effect, operating through the level and quality/productivity of other inputs to the child human capital production function that may be influenced by mother's nutritional status. The direct effect of mother's adolescent nutritional status on child health reflects that mother's nutritional status during adolescence may be crucial for their nutritional status during pregnancy and lactation that biologically

\footnotetext{
${ }^{1}$ This is the case in a forward-looking framework of child human capital determination under which mother's undernutrition in adolescence is determined by mother's decisions simultaneously with the choice of investments on child human capital in future periods.
} 
determines child nutritional status during this prenatal and postnatal period as well as in subsequent periods (Martorell and Zongrone, 2012). Moreover, given the link between child nutrition and brain development in early life, this may further support a direct effect of maternal nutrition on child cognitive development (Prendergast and Humphrey, 2014; Glewwe et al., 2001). Indirect effects of mother's undernutrition in adolescence on child human capital may manifest through lower level and quality of investments in child human capital. This may be due to mother's lower human capital (Strauss and Thomas, 1998; Schick and Steckel, 2015) that is associated with lower labour productivity and income, as well as parenting skills (Furstenberg et al., 1989; Francesconi, 2008).

Estimating (1) by OLS is expected to yield biased and inconsistent estimates of the effect of interest. This is because $M N_{i}$, which partly reflects the maternal health endowment, is expected to be correlated with child health and cognitive endowments, subsumed in $\alpha_{i}$, as well as with unobserved time-varying determinants of child human capital realised prior to mother's adolescence, subsumed in $\varepsilon_{i a}$. Another source of bias in the OLS estimator of $\beta_{1}$ in (1) may also arise from measurement error in maternal adolescent nutritional status, normally captured by adolescent growth (change in height), which is expected to partly reflect genetic variation unrelated to nutrition. The latter is expected to be correlated with genetic variation in child height-for-age, the standard measure of child health and nutritional status used in the literature (Glewwe and Miguel, 2008). ${ }^{2}$ This makes it difficult to infer the extent to which the OLS estimate of $\beta_{1}$ reflects an intergenerational transmission of undernutrition and the extent to which it reflects an intergenerational genetic transmission of height.

We address the above estimation problems through Instrumental Variables (IV) using rainfall shocks during mother's adolescence as instruments for mother's adolescent nutritional

\footnotetext{
${ }^{2}$ Based on equation (1) this could be expressed as a correlation between the measure of $M N_{i}$ and $\alpha_{i}$, as the latter including measurement error in $H C_{i a}$. In the case that the dependent variable is child achievement test scores, genetic variation in height may also be correlated with child cognitive endowment if there is a genetic correlation between physical stature and innate mental ability (Glewwe et al., 2001).
} 
status. Rainfall shocks, defined as deviations from locality long-run trends, are expected to be valid instruments for maternal adolescent nutritional status, as they are expected to be uncorrelated with child endowment in $\alpha_{i}$, and with unobserved factors determined prior to mother's adolescence, subsumed in $\varepsilon_{i a}$, because they are unanticipated prior to adolescence. They are also expected to be uncorrelated with measurement error in maternal and child nutritional status arising from genetic variation in maternal and child height, respectively.

Rainfall shocks during mother's adolescence are also expected to address bias arising from another source of measurement error present in our case, as due to data availability (see next section for details), we use maternal adult height as an indicator of mother's nutritional status in adolescence. In particular, maternal adult height can be expressed as the sum of height at the beginning of adolescence and growth during adolescence. ${ }^{3}$ The latter is the actual measure of adolescent nutritional status and the former is similar to measurement error, which is expected to be uncorrelated with rainfall shocks in adolescence.

Rainfall shocks during adolescence are hypothesised to impact nutrition and growth through two channels. The first is a disease channel, as higher than average precipitation leads to an increase in the incidence of diarrheal diseases and results in lower absorption of nutrients by the body and growth faltering (Ramani et al., 2017; Thiam et al., 2017). The second is an income channel, which is expected to be relevant mainly in rural contexts, as somewhat higher than average rainfall is strongly linked to agricultural productivity and income (Skoufias and Vinha 2012; Dell, Jones, and Olken 2014). This channel is expected to lead to a positive relationship between rainfall shocks and human growth (Skoufias and Vinha, 2012).

If the income channel is the main channel through which the impact of rainfall shocks on growth manifests, then the exclusion restriction required for identification may be violated, as

\footnotetext{
${ }^{3}$ Adolescence is normally defined as the period from 10 to 19 years, when growth has terminated (WHO, 2012).
} 
rainfall shocks may impact child human capital through other channels than maternal nutrition. We investigate this as part of our analysis presented in one of the following sections.

We also complement IV estimation with an alternative strategy, which allows us to gauge the effect of maternal growth in adolescence and child human capital and is based on OLS estimation of the reduced-form relationship linking rainfall shocks and child outcomes (Angrist and Krueger, 1999). This approach, on the one hand, offers indirect evidence of the relationship between maternal adolescent undernutrition and child human capital, but on the other hand, it is not plagued by several of the limitations of IV, including potential violation of the exclusion restriction, weak instruments, and misleading inferences due to low power (Angrist and Krueger, 1999; Young, 2020).

We investigate the channels via which maternal undernutrition impacts child outcomes through performing mediation analysis by extending equation (1) to include (direct or indirect) measures of parental investments observed after adolescence and prior to the measurement of child outcomes. Comparisons of coefficient estimates of $M N_{i}$ between models with and without mediators allows us to infer the extent to which the impact of maternal undernutrition in adolescence on child human capital manifests through a behavioural channel. We note, however, that this exercise can only be suggestive of causal channels, as it does not address the endogeneity of mediators, which is very challenging considering the number of mediators examined. Thus, results of our mediation analysis should be interpreted with caution.

\section{DATA AND DESCRIPTIVE STATISTICS}

The data used in our analysis are from Young Lives, an international cohort study of childhood poverty in Ethiopia, India (the states of Andhra Pradesh and Telangana), Peru, and Vietnam. Young Lives has followed over time around 2,000 children in each country born in 
2001/02 collecting information through five surveys in 2002, 2006, 2009, 2012, and 2015, when children were around $1,5,8,12$, and 15 years old, respectively. ${ }^{4}$

The study collects rich information on a range of child characteristics and outcomes as well as characteristics of the primary caregiver, who in most cases is the child's biological mother, and the locality the child's household resides in (see Barnett et al., 2013 and Crookston et al., 2013 for details).

Nutritional status for children at different ages was measured by height-for-age Z-scores (HAZ) calculated using the 2006 WHO standard for children younger than 5 years old (WHO Multicentre Growth Reference Study Group 2007) and the 2007 WHO reference for children older than 5 years (de Onis et al., 2007). Supine length, at age 1 year, and height at 5, 8, 12, and 15 years were measured to $1 \mathrm{~mm}$ using standardized length boards and stadiometers. As discussed in the previous section, maternal nutritional status was measured using maternal height in cm, which was collected once, in 2006 (Round 2), when all mothers were adults (between 21 and 48 years old).

Descriptive statistics of child height-for-age Z-scores and maternal adult height across countries and for the pooled sample are presented in Table 1. The table also presents descriptive statistics for other child and parental characteristics used in our analysis, either as controls, such as child age and gender, or as mediators, such as measures of parental human capital and socioeconomic status and investments on child health. ${ }^{5}$

The sample for which descriptive statistics are reported includes children with nonmissing HAZ scores or non-missing test scores at all rounds. Extreme values of child HAZ scores (greater than 6 in absolute value) (de Onis, 2007) at any age are also treated as missing.

\footnotetext{
${ }^{4}$ Young Lives collects information also on a cohort of children born in 1994/95, but these were not used in our analysis, as they were not followed since infancy and early childhood and thus one cannot trace the impacts of maternal undernutrition on child outcomes since early life.

${ }^{5}$ Descriptive statistics of other variables used in our analysis, such as mother's ethnicity, parental health investments at age 8,12 , and 15 years and language in which tests were administered to children, are presented in Tables A1 and A2 in the Appendix.
} 
In order to maximise the estimation sample, we imputed missing values of mediating variables (prevalence 0.004 per cent to 9 per cent) - there were no missing values for the control variables - and we included dummies for imputed values in estimated specifications.

Table 1 suggests that child HAZ scores have improved slightly except of India and that mother's average height is the highest in Ethiopia and the lowest in Peru.

Cognitive development of Younger Cohort children was assessed at ages 5, 8, 12, and 15 years using quantitative achievement tests. Tests included the quantitative component of the Cognitive Developmental Assessment (CDA) at age 5 and a mathematics test at ages 8, 12, and 15. The quantitative component of the CDA aims to assess child's understanding of notions such as few, most, half, many, equal, a pair etc. In particular, it requires children to indicate which one of a set of pictures fits the description in each of 15 statements, such as 'Point to the plate that has few cupcakes' (Cueto, Leon, Guerrero, and Muñoz 2009). The mathematics test includes 29 items $^{6}$ on counting, number discrimination, knowledge of numbers, and basic operations with numbers. Extensive analysis of the psychometric characteristics of these tests indicated high reliability and validity of test items (Cueto and León 2012; Cueto et al. 2009). All tests were administered in the language with which the child felt most comfortable. Table 1 shows systematic differences in performance in quantitative achievement tests across countries.

Rainfall shocks during mother's adolescence were calculated by matching precipitation data from the Global Climate Database of the University of Delaware (UDEL) (Willmott and Matsuura 2012) in the period 1950-2014 to the communities mothers were residing during their adolescent years. This used information on mother's year of birth and history of locations available in the Young Lives data. Mother's year of birth was identified using repeated

\footnotetext{
${ }^{6}$ In Ethiopia 28 items were administered at age 12 and 26 items at age 15 years, whereas in Peru 34 items were administered at age 12, and in Vietnam 30 items were administered at age 15 years.
} 
information on mother's age in completed years and information on the date of the interview across rounds, which allows us to minimise measurement error arising from age misreporting.

The UDEL data include information on monthly total precipitation and have spatial resolution of $0.5 \times 0.5$ degrees that corresponds roughly to grids that are 35 miles across at the equator (see Auffhamer et al., 2013 and Dell, Jones, and Olken, 2014 for detailed discussions). We calculated monthly deviations of rainfall from the locality/season and year average by obtaining the residuals from a regression of the monthly level of precipitation on dummies of interactions of locality and calendar month and dummies for year. In this way, we purged rainfall variation from locality and seasonality combined fixed effects and year fixed effects that may be also correlated with mother and child outcomes. These residuals were then aggregated to produce rainfall deviations/shocks for each calendar year in mother's adolescence, defined as the period between age 10 and 19 years inclusive, consistent with international definitions (WHO, 2012; Campisi et al., 2018).

This allows us to calculate rainfall shocks during an age range of mother's adolescence spanning one year and not at a particular age. For example, measuring rainfall deviation from the locality average in the calendar year a mother completed 12 years, provides a measure of the rainfall shock in a period during which the mother was between 11 and 12 years old. For simplicity, in the analysis that follows, we will refer to the rainfall shock in the calendar year the mother turns 12 years old, as the shock at 12 years.

Rainfall shocks averages and standard deviations, measured in $\mathrm{cm}$, from the $10^{\text {th }}$ to the $19^{\text {th }}$ year of mother's life and across countries are presented in Table 1. Averages are, in most cases, close to zero because shocks are calculated as deviations from the locality and year mean.

\section{RESULTS}

III.1 Maternal Adolescent Nutritional Status and Child Outcomes 
This section presents results from the estimation of equation (1), expressing the relationship between maternal nutritional status in adolescence, as measured by adult height, and child human capital, as measured by HAZ and quantitative achievement test scores. All estimated specifications control for child age at the time the child outcome was measured and child gender as well as maternal ethnicity, the only outcome determined prior to mother's adolescence on which there is information in the data. ${ }^{7}$ Clustered standard errors are reported in all cases, either at the sentinel site level - when the main independent variable of interest is mother's height that takes into account the sampling design ${ }^{8}$ - or at the level of the community the mother was residing prior to adolescence - when the main independent variable is the rainfall shock that takes into account that rainfall varies across communities. However, in the latter case, we also present results based on robust standard errors in the Appendix (Tables A3A5) as a check of the robustness of our inferences.

Table 2 reports OLS estimation results for equation (1), where the dependent variable is child HAZ score at different ages, by country and for the pooled countries sample. Estimates indicate a significant and positive association between maternal adult height and child HAZ score that persists across ages.

Table 3 presents OLS estimates of the impact of rainfall shocks at different years of mother's adolescence on mother's adult height by country and for the pooled countries sample. These are estimates of the first-stage relationship required to assess the reliability of Two-Stage Least Squares (TSLS) estimation of equation (1). Results suggest that rainfall in mother's $13^{\text {th }}$

\footnotetext{
${ }^{7}$ There is also information on mother's community of residence prior to adolescence, but this is not included in estimation, as in most cases, communities included a single individual. This, however, is not expected to affect the consistency of the IV estimator, considering that, by construction, shocks are uncorrelated with fixed locality characteristics.

${ }^{8}$ In the case of country-specific samples, clustered standard errors may provide poor estimates of standard errors due to the small number of clusters (Angrist and Pischke, 2009; Cameron and Miller, 2015). We did not, however, find evidence of marked differences in p-values of significance tests based on clustered standard errors and pvalues based on wild cluster bootstrap that performs better when the number of clusters is small (Cameron et al., 2008) (results are available from the lead author upon request). Thus, we chose to report clustered standard errors also because it is not possible to compute standard errors when using the wild cluster bootstrap approach (Cameron et al., 2008).
} 
year is the only shock that has a significant effect on adult height across countries - the rainfall coefficient is only marginally insignificant in India - and in the pooled countries sample. The effect is positive in Ethiopia, consistent with the income channel linking rainfall shocks and human growth, and negative in the other countries and in the pooled sample, consistent with the disease channel. The same holds for effects of rainfall shocks in other periods. Another difference across countries is that shocks in late adolescence have a significant effect on adult height only in Ethiopia.

We perform a range of tests to investigate the robustness of these patterns. First, we use Bonferroni corrected p-values that adjust for multiple testing, as specifications estimating the relationship between rainfall shocks in adolescence and maternal adult height consider 10 different shocks. Bonferroni corrected p-values for tests of significance of the effects of the different rainfall shocks are reported in squared brackets below coefficient estimates in Table 3. These show that, adjusting for multiple testing, does not affect the significance of the effect of the rainfall shock in mother's $13^{\text {th }}$ year of life on mother's adult height in Peru and in the pooled sample.

Second, we check the reliability of conventional tests of significance of individual rainfall shocks coefficients by computing p-values using permutation tests (Fisher, 1935; Young, 2019), implemented through reshuffling each rainfall shock across years and communities. These tests reinforce the pattern identified by conventional significance tests that rainfall shocks during the mother's $13^{\text {th }}$ year have a significant effect on her adult height across all countries.

A potential explanation of the significant impact of the rainfall shock during the mother's $13^{\text {th }}$ year of life - or to be more precise, during the period mothers were between 12 and 13 years old - on mother's adult height is that this year may coincide with the period of peak height velocity during the pubertal growth spurt (Eckert et al., 2009; Das et al., 2017; Campisi 
et al., 2018). In particular, peak height velocity is normally between 11 and 12 years of age, but in low-income settings the pubertal growth spurt is extended, and thus peak height velocity occurs at a later age (Eckert et al., 2009; Das et al., 2017). Nevertheless, these effects appear small, ranging from 0.01 to $0.03 \mathrm{~cm}$ higher height for a every additional centimetre higher than average rainfall in the locality. ${ }^{9}$

We also perform a placebo test of the robustness of the effects of rainfall shocks on mother's height through investigating the relationship between rainfall shocks realised after mother's height was measured. In particular, we regress mother's height, observed in Round 2, on rainfall shocks after Round 2, in the years children were 7, 8, 9, and 10 years old. Results (presented in Table A6 in the Appendix) do not show a systematic and significant relationship between rainfall shocks in these periods and mother's height across countries and in the pooled sample that provides additional support to the robustness of our results. ${ }^{10}$

Although, there is evidence of a significant effect of rainfall shocks during mother's adolescence on mother's adult height, partial F-statistics, presented in Table 3, suggest that these are expected to be weak instruments for mother's adult height. Therefore, TSLS estimates are expected to be unreliable. In order to minimise problems arising from weak instruments, we conduct TSLS estimation using as a single instrument the rainfall shock during the mother's $13^{\text {th }}$ year of life and pooling the samples from India, Peru, and Vietnam (Angrist and Pischke, 2009). This also reduces concerns related to the validity of the exclusion restriction by restricting the sample to the countries in which the effect of rainfall shocks on height is negative and thus manifesting mainly through the disease channel.

\footnotetext{
${ }^{9}$ These effects are similar or slightly smaller than existing studies looking at the impact of rainfall shocks on adult height (Pathania, 2007; Maccini and Yang, 2009). Nevertheless, our results are not directly comparable with these studies, as these differ from our study along a few dimensions: i) they investigate at the effects of rainfall shocks in early years of life; ii) some of these studies consider large deviations of rainfall, i.e., droughts, iii) they mainly find a positive effect, suggesting that the effect operates pre-dominantly via an income channel.

${ }^{10}$ We find that only one out of the twenty rainfall shocks coefficients across samples is significant at $5 \%$ that may be in line with that the only significant coefficient may have arisen due to chance.
} 
Estimation results by TSLS are presented in Table 4. First-stage F-statistics across TSLS estimated specifications, presented in Table 4, are sufficiently high, suggesting no concerns related to a weak instrument. Estimates show a positive and significant effect of maternal nutritional status during adolescence on child nutritional status at age 1 year that persists through age 15 year. As Table 4 indicates, TSLS estimates are of medium size, but much larger than OLS. TSLS estimates suggest that $1 \mathrm{~cm}$ higher maternal growth during adolescence leads, on average, to around 0.19 standard deviations higher child height relative to the WHO reference child of the same age and gender at age 1 year, and that this effect is sustained through to age 15 years.

Our mediation analysis explores putative channels through which maternal adolescent nutrition impacts child outcomes, as discussed in one of the previous sections and presented in Figure 1. As Figure 1 shows, our analysis first investigates whether the effect of maternal adolescent nutrition on child growth at age 1 year manifests through altering parental health investments on the child; second, it considers whether the effect of maternal adolescent nutrition on child growth in subsequent years operates through or over and above child growth in interim periods; third, it examines whether effects operating over and above child growth in interim periods are due to parental investments responses to maternal adolescent nutrition, which are implemented after these periods; and fourth, it investigates whether an effect through child growth in interim periods manifests through parental investments responses to child growth in interim periods, which are implemented in subsequent periods. In this way, our analysis allows us to sketch out the full set of temporal pathways linking maternal adolescent nutrition and child outcomes over the child's life course.

Our mediation analysis results are summarised in Figures 2a to 2e (see also Tables A7i to A7iv in the Appendix for full estimation results). Figure 2a presents the TSLS estimates of the effect of maternal adolescent nutrition on child HAZ at age 1 year in the base specification, 
including only controls, and a specification also including a range of proxies for parental investments at age $1 \mathrm{y}$, such as measures of parental socioeconomic status. ${ }^{11}$ The figure shows no noticeable difference between the two estimates, suggesting that parental investments at age $1 \mathrm{y}$ do not appear to be a mediator of the relationship between maternal adolescent nutrition and child HAZ at age 1 year. The same holds for the relationship between maternal adolescent nutrition and child HAZ at age 5 years, as showed by Figure $2 b$. Figure $2 b$, however, shows that the inclusion of HAZ at age 1 year among the explanatory variables in the specification for $\mathrm{HAZ}$ at age 5 year reduces the coefficient of maternal height markedly, but the coefficient remains statistically significant (the confidence interval does not cross the 0 line). This implies that the effect of maternal adolescent nutrition on child HAZ at age 5 years operates partly through and partly over and above child HAZ at age 1 year. Nevertheless, as shown by Figure $2 \mathrm{~b}$, inclusion of direct measures of parental investments on child health at age 5 years, such as expenditure on child health, child's dietary diversity and number of meals in the last 24 hours, does not change the coefficient of maternal height, as well as the coefficient of HAZ1 (see Table $7 \mathrm{i}$ in the Appendix). This implies that effects of maternal adolescent nutrition on child $\mathrm{HAZ}$ at age 5 year - manifesting either through or over and above HAZ at age 1 year - may not be explained by (observed) parental investment responses, and thus are likely possibly reflect mainly biological effects.

Results on potential channels through which effects of maternal adolescent nutrition on child HAZ at age 8, 12, and 15 years, are presented in Figures 2c, 2d, and 2e, respectively, and lead to similar conclusions as those for child HAZ at age 5 year. The first conclusion is that the effect of maternal adolescent nutrition on child nutritional status at any given period manifests partly through child nutritional status in interim periods. Specifically, estimates in Figures 2c,

\footnotetext{
${ }^{11}$ These were used, because, contrary to other rounds, there are no direct measures of parental health investments on the child in Round 1.
} 
$2 \mathrm{~d}$, and $2 \mathrm{e}$ show that effects of maternal adult height on child HAZ at age 8, 12, and 15 years, are mainly mediated by child HAZ at age 1 and 5 years, as inclusion of these in the specifications - particularly HAZ at age 5 years - reduces the estimated effects substantially and renders them insignificant. This may explain the persistent effect of maternal adolescent nutrition on child growth from early childhood to adolescence. The second conclusion from our results is that there is no evidence that the effect of maternal adolescent nutrition on child nutrition from infancy to adolescence is mediated by parental health investments in the child. ${ }^{12}$

Turning to estimation results of the relationship between maternal adult height and child quantitative achievement test scores at different ages, presented in Table 5, OLS estimates show a positive and significant association between the two that persists as children age. TSLS estimates, however, do not indicate a significant effect of maternal adolescent nutritional status on child cognitive development at any age. Although, this could be the result of larger standard errors arising from the smaller estimation sample compared to specifications with child HAZ as the dependent variable, we find no supporting evidence on this. We find that effects on child HAZ remain strongly positive and significant across ages even when the sample is restricted to the same sample as that for test scores at all ages (see Table A8 in the Appendix for details). This suggests that maternal adolescent nutritional status has larger and more systematic effects on child nutritional status than on child cognitive development. This seems to be in line with what one would expect considering that the relationship between maternal nutrition and child cognition may be mainly indirect, mediated through child nutritional status (Veena et al., 2015). Nevertheless, the lack of significant effects of maternal adolescent nutrition on child cognition may seem puzzling, considering its strongly significant effect on child nutrition and the evidence supporting a strong positive link between child nutrition and cognitive development

\footnotetext{
${ }^{12}$ The evidence on this presented here is suggestive rather than conclusive, as in some cases child health investments measures do not have significant associations with child HAZ or because we cannot rule out that there are unobserved child health investments responses to maternal adolescent nutritional status.
} 
(Glewwe et al., 2001). A potential explanation of this may be that cognitive development of children who were undernourished in early childhood may improve in later periods of life, even in the face of persistent undernutrition, through compensatory parental investments in child education (Mendez and Adair, 1999; Galasso et al., 2016). ${ }^{13}$

Overall, our results seem to suggest that the effect of maternal adolescent nutrition on child nutritional status from infancy to adolescence is likely to mainly operate through a biological channel reflecting direct transmission of undernutrition through early childhood. Moreover, this effect seems to persist through to adolescence because early childhood nutrition is a strong predictor of nutritional status in subsequent stages of life. These results have important policy implications, as they suggest that the intergenerational transmission of undernutrition in low- and middle-income countries may be more effectively addressed through interventions promoting the nutrition of adolescent girls as well as children's nutrition before age 5 years.

\section{III.2 Rainfall Shocks during Mother's Adolescence and Child Outcomes}

This section presents results on the relationship between rainfall shocks during mother's adolescence and child outcomes. As discussed in one of the previous sections, this analysis aims to provide an additional indirect test of the robustness of the link between maternal adolescent nutritional status and child outcomes documented in the previous section through estimating the reduced-form relationship between the instrument and child outcomes. It also allows us to identify whether results in the pooled sample may be driven by a particular country, that was not possible when using TSLS, through investigating differences on the

\footnotetext{
${ }^{13}$ We have explored this by looking at the effect on maternal adult height on a range of educational inputs. Although there is some evidence of compensatory investments, such as more time spent in school and studying at home at age 5 years among children of shorter mothers, this effect is insignificant (results are available from the lead author upon request).
} 
impact of shocks influencing mother's nutrition during adolescence on child outcomes across countries.

The top panel of Table 6 presents OLS estimation results of the effect of the rainfall shock during the mother's $13^{\text {th }}$ year of life on child HAZ at different ages in the sample resulting by pooling children from India, Peru, and Vietnam on which TSLS estimation in the previous section was based. Coefficient estimates reveal a negative and significant effect of rainfall in mother's $13^{\text {th }}$ year of life on child HAZ at all ages. Effects, however, are small in magnitude, as estimates suggest that $1 \mathrm{~cm}$ higher rainfall, during the period mothers were between 12 and 13 years old, lead, on average, to around 0.0025 standard deviations higher child height relative to the WHO reference child of the same age and gender at any given age. Effects do not also change when the sample is restricted to children with non-missing observations in both HAZ and achievement tests in all rounds (see Table A9 in the Appendix for details). Moreover, reduced-form OLS estimates are in line in terms of sign and significance with OLS estimates of the first-stage equation and TSLS estimates of equation (1) using rainfall in mother's $13^{\text {th }}$ year of life as an instrument for mother's adolescent nutritional status, presented in the previous section.

Results presented in the other panels of Table 6 are consistent with negative effects of the rainfall shock in the mother's $13^{\text {th }}$ year on child HAZ at age $1 \mathrm{y}$ across the three countries, i.e., India, Peru, and Vietnam - although this is weakly significant only in India - with the effect persisting at older ages in Peru and Vietnam.

Mediation analysis results investigating the potential channels through which the effect of the rainfall shock in mother's adolescence may manifest are presented in Figures 3a to 3e (full estimation results are presented in Tables A10i to A10iv in the Appendix). The patterns of estimates are similar qualitatively with those identified for maternal nutritional status in the previous section: the effect of the rainfall shock on child HAZ does not seem to manifest 
through parental health investments, whereas its effect on child HAZ after age 5 years seems to mainly manifest through child HAZ at or before age 5 years. Moreover, estimates in Figures 3a to $3 e$ show that effects of rainfall shocks on child HAZ do not change much after the inclusion of other maternal outcomes, such as education and household income, that may provide additional support to the exclusion restriction that rainfall shocks impact mother's growth and nutrition mainly through a disease channel rather than an income channel.

Finally, Table 7 presents OLS estimation results of the impact of rainfall shock during the mother's $13^{\text {th }}$ year of life on child quantitative achievement test scores at different ages. Estimates show small and insignificant effects at all ages in the pooled sample that reflect mainly small and insignificant effects across countries.

All in all, results in this section support a significant and persistent effect of rainfall deviations from the norm during the mother's early adolescence on her offspring's growth through the life course that is likely to manifest mainly through a biological channel, but no significant effect on her offspring's cognitive development. This is in line with our findings in the previous section supporting a strong and persistent link between maternal nutrition during adolescence and child growth; and no link between maternal adolescent nutrition and child cognitive development.

\section{CONCLUSION}

Although adolescence has been highlighted as a period when investments and environments are critical for the human capital development of women and their children, there is very little evidence on this from LMICs. In particular, many have argued that adolescence is a critical period for height formation and presents opportunities for remediation of deficits in growth arising from undernutrition in the early years of life. Nevertheless, this is not yet wellestablished, and little is known on the responsiveness of growth during adolescence to 
environmental insults as well as the long-run and intergenerational implications of maternal nutrition during adolescence

In this paper, we use data from an international cohort study in Ethiopia, India, Peru, and Vietnam to identify the effect of mother's undernutrition in adolescence for her child's growth and cognitive achievement from infancy through middle adolescence as well as the potential channels through which these effects may manifest. Our analysis addresses potential biases in estimation arising from the endogeneity of mother's nutritional status through an IV identification strategy employing rainfall shocks during mother's adolescence as instruments for mother's adolescent nutritional status. We also examine the impacts of rainfall shocks during the mother's adolescent years on maternal adult height and child growth and development over the life course as an additional way to examine the long-run and intergenerational impacts of nutritional insults during adolescence that has been little investigated in the literature.

We find evidence that better maternal nutrition in adolescence leads to significantly higher child growth from infancy to adolescence but does not significantly improve child performance in achievement tests. Our analysis further suggests that the effect of maternal adolescent nutrition on child nutrition is likely to manifest mainly through a biological channel that reflects a direct intergenerational transmission of undernutrition. This effect is reflected in poor child growth through age 5 years and persists through to adolescence due to the strong positive link between growth in early childhood and growth in subsequent stages of development.

Overall, our findings have important policy implications and suggest that interventions that aim to improve the nutritional status of girls during early adolescence may contribute to breaking the intergenerational cycle of undernutrition in low- and middle-income countries. 
Figure 1: Mechanisms linking maternal adolescent nutrition and child growth over the life course

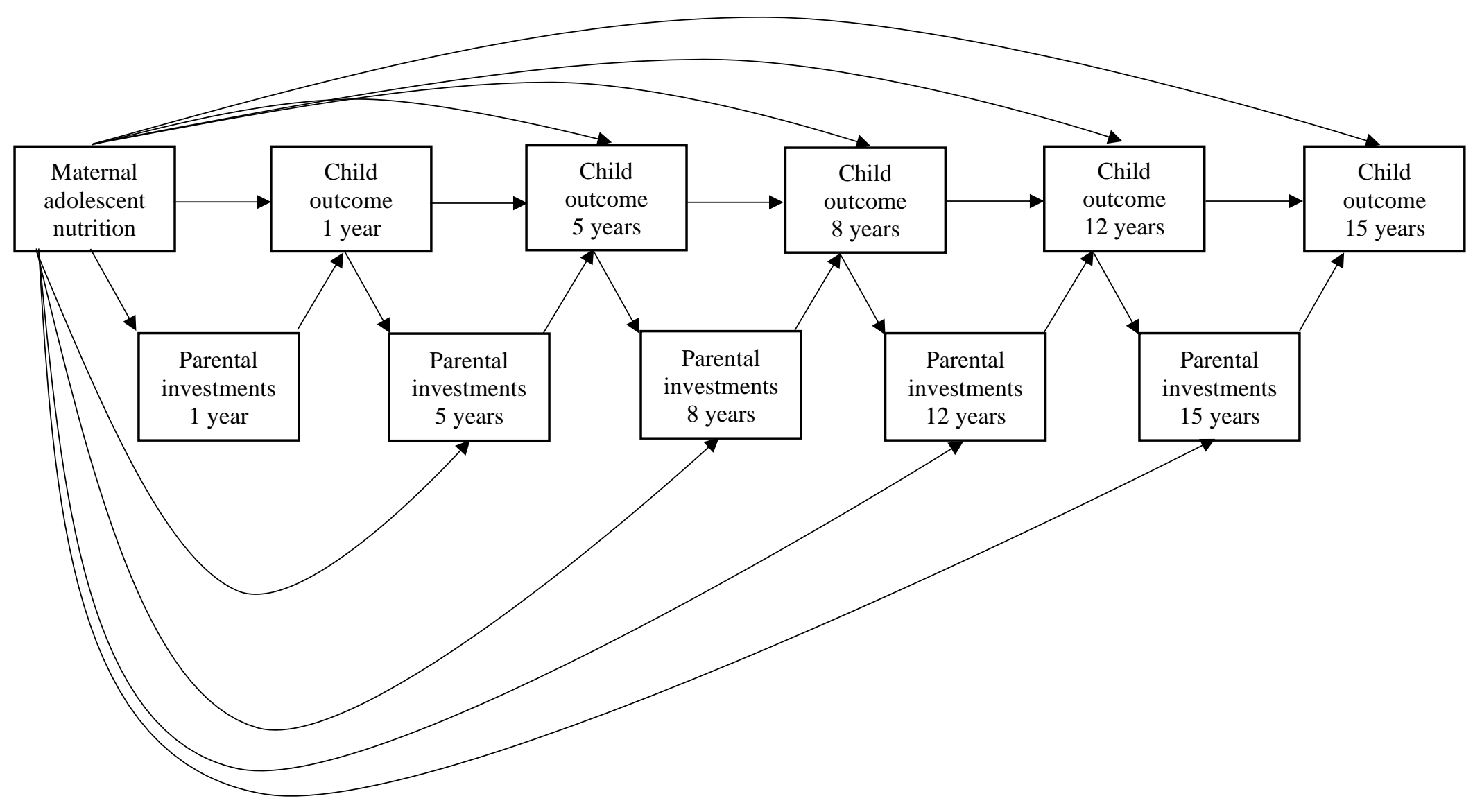


Figure 2a: TSLS coefficient estimates of the impact of maternal adolescent nutritional status on child height-for-age z-scores (HAZ) at age $1 \mathrm{y}$ across specifications including mediators in the India, Peru, and Vietnam pooled sample

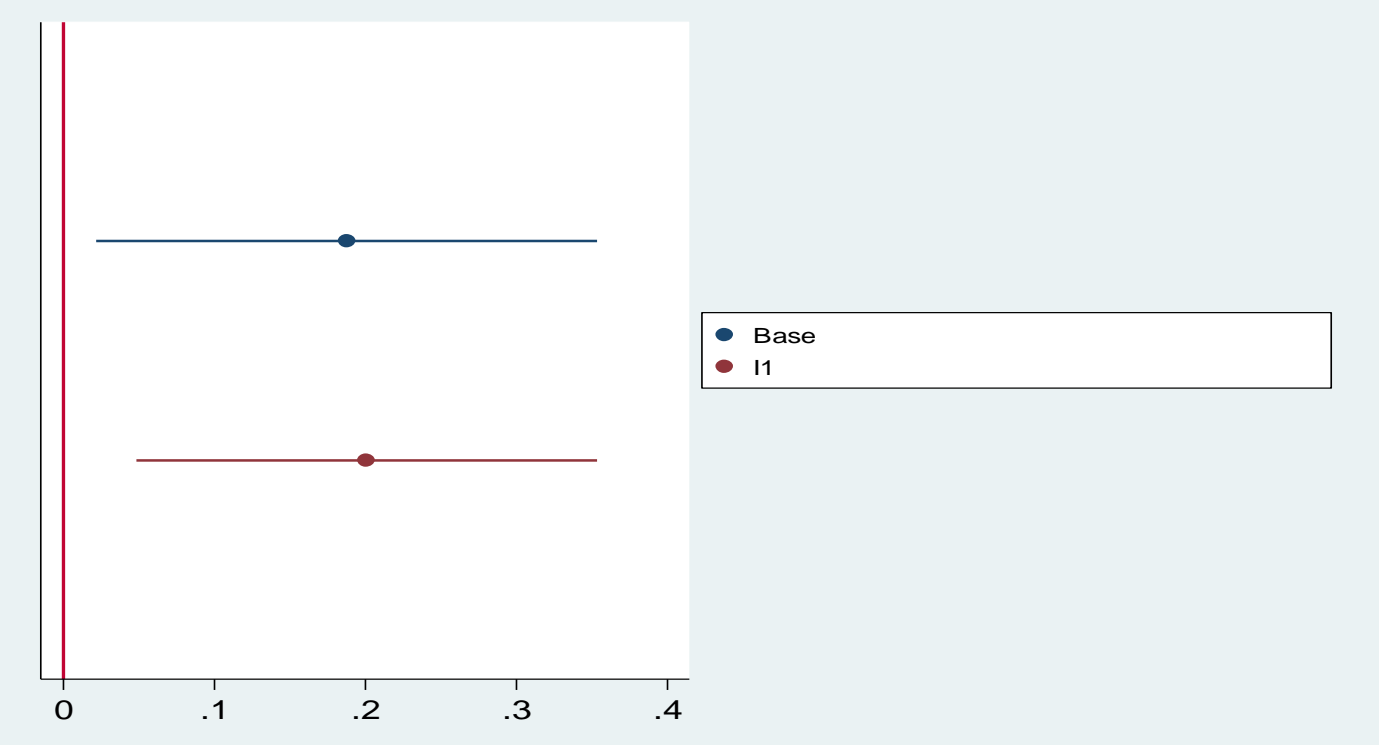

Notes: Figure displays coefficient estimates and associated $95 \%$ confidence intervals. Base denotes the base specification including child gender and age and mother's ethnicity. I1 denotes a specification including controls in the base specification and parental investments on child health at age 1 year as a mediator. Parental investments on child health at age 1 year are approximated by parental education, household wealth, and urban location.

Figure 2b: TSLS coefficient estimates of the impact of maternal adolescent nutritional status on child $\mathrm{HAZ}$ at age $5 \mathrm{y}$ across specifications including mediators in the India, Peru, and Vietnam pooled sample

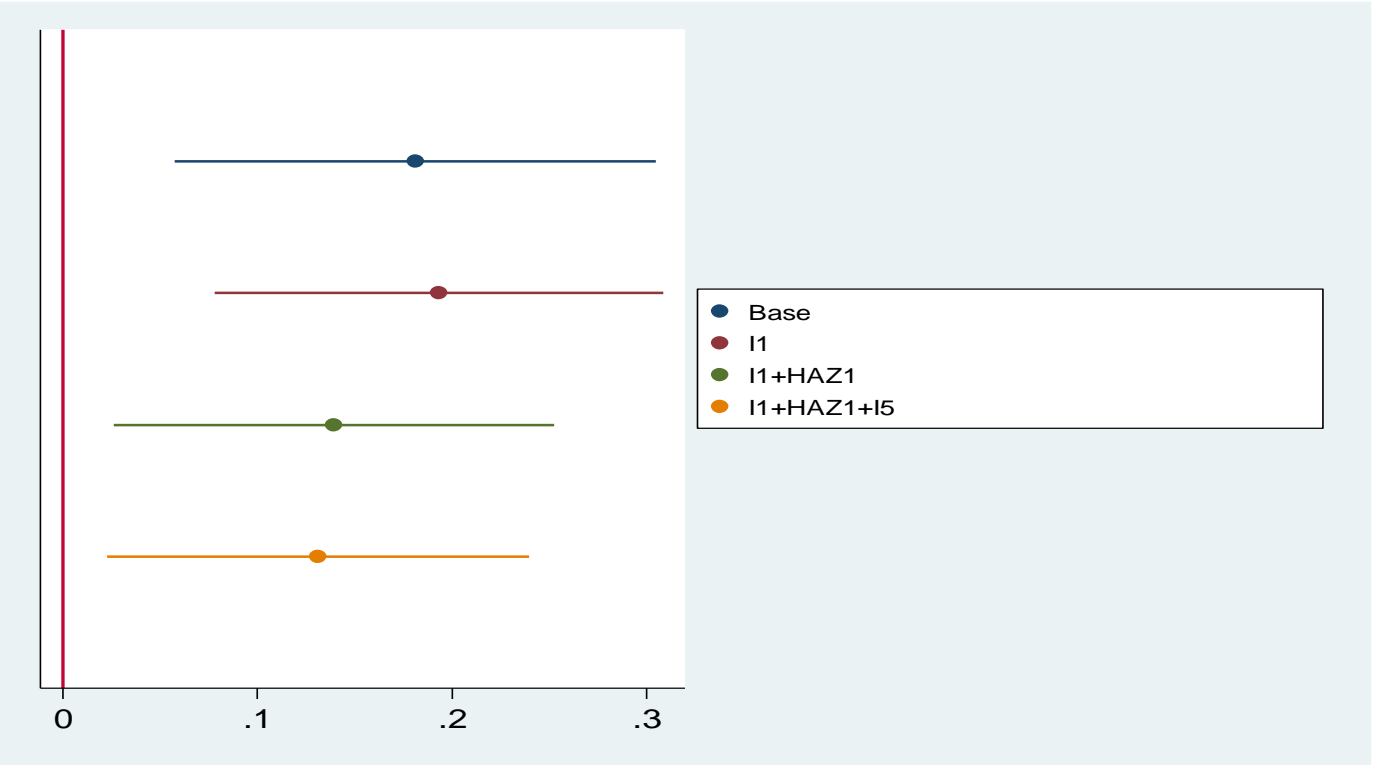

Notes: Figure displays coefficient estimates and associated $95 \%$ confidence intervals. Base denotes the base specification including child gender and age and mother's ethnicity. I\# denotes a specification including controls in the base specification and parental investments on child health at age \# as a mediator. Parental investments on child health at age 1 year are approximated by parental education, household wealth, and urban location; whereas parental investments on child health at all ages above 1 year are measured by expenditure on child's health, child's diversity score and number of meals consumed by the child in last 24 hours. HAZ1 denotes a specification including $\mathrm{HAZ}$ at age $1 \mathrm{y}$ as a mediator. 
Figure 2c: TSLS coefficient estimates of the impact of maternal adolescent nutritional status on child HAZ at age 8 y across specifications including mediators in the India, Peru, and Vietnam pooled sample

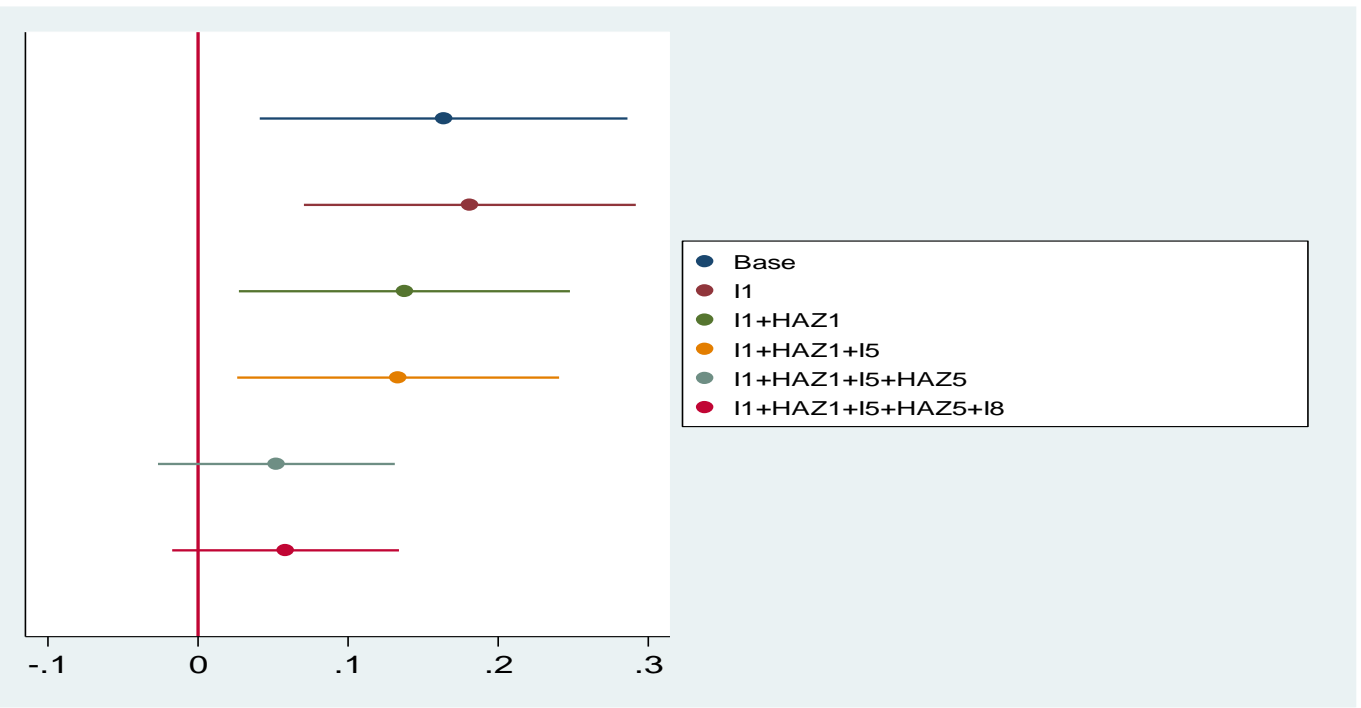

Notes: Figure displays coefficient estimates and associated $95 \%$ confidence intervals. Base denotes the base specification including child gender and age and mother's ethnicity. I\# denotes a specification including controls in the base specification and parental investments on child health at age \# as a mediator. Parental investments on child health at age 1 year are approximated by parental education, household wealth, and urban location; whereas parental investments on child health at all ages above 1 year are measured by expenditure on child's health, child's diversity score and number of meals consumed by the child in last 24 hours. HAZ\# denotes a specification including HAZ at age \# $\mathrm{y}$ as a mediator.

Figure 2d: TSLS coefficient estimates of the impact of maternal adolescent nutritional status on child HAZ at age $12 \mathrm{y}$ across specifications including mediators in the India, Peru, and Vietnam pooled sample

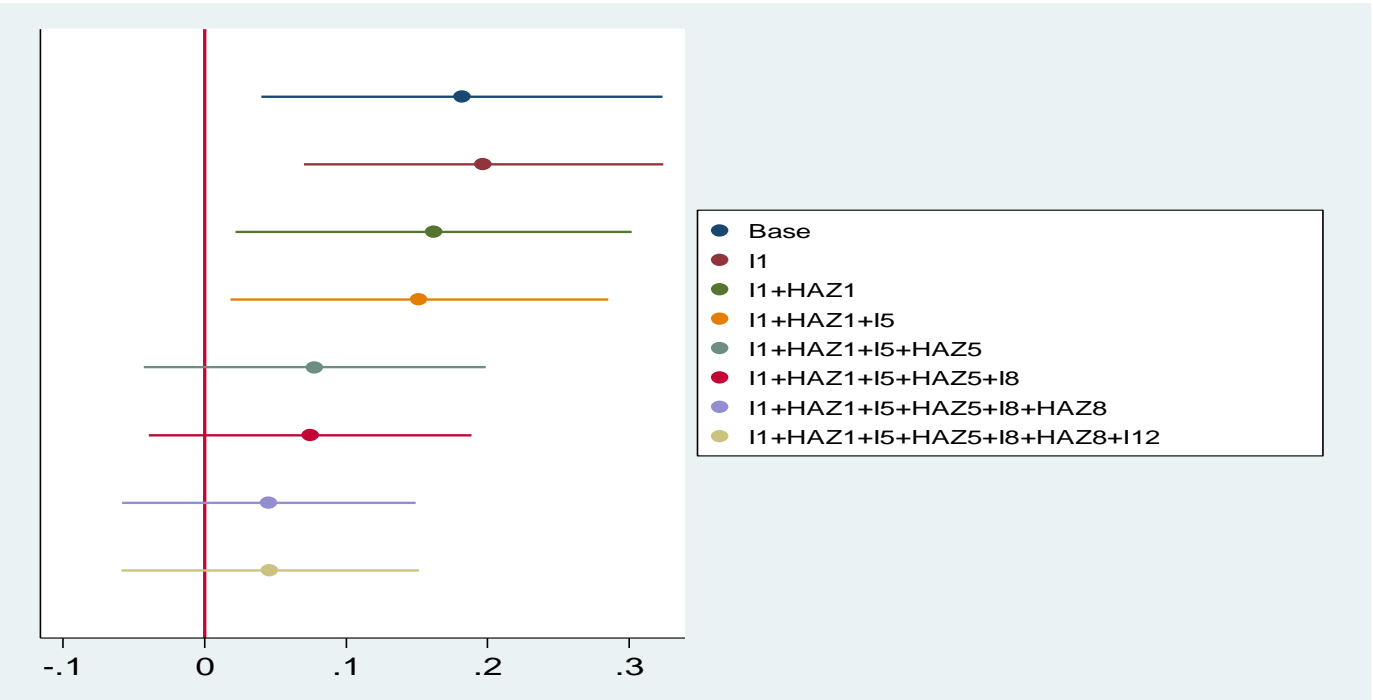

Notes: Figure displays coefficient estimates and associated $95 \%$ confidence intervals. Base denotes the base specification including child gender and age and mother's ethnicity. I\# denotes a specification including controls in the base specification and parental investments on child health at age \# as a mediator. Parental investments on child health at age 1 year are approximated by parental education, household wealth, and urban location; whereas parental investments on child health at all ages above 1 year are measured by expenditure on child's health, child's diversity score and number of meals consumed by the child in last 24 hours. HAZ\# denotes a specification including $\mathrm{HAZ}$ at age \# $\mathrm{y}$ as a mediator. 
Figure 2e: TSLS coefficient estimates of the impact of maternal adolescent nutritional status on child $\mathrm{HAZ}$ at age $15 \mathrm{y}$ across specifications including mediators in the India, Peru, and Vietnam pooled sample

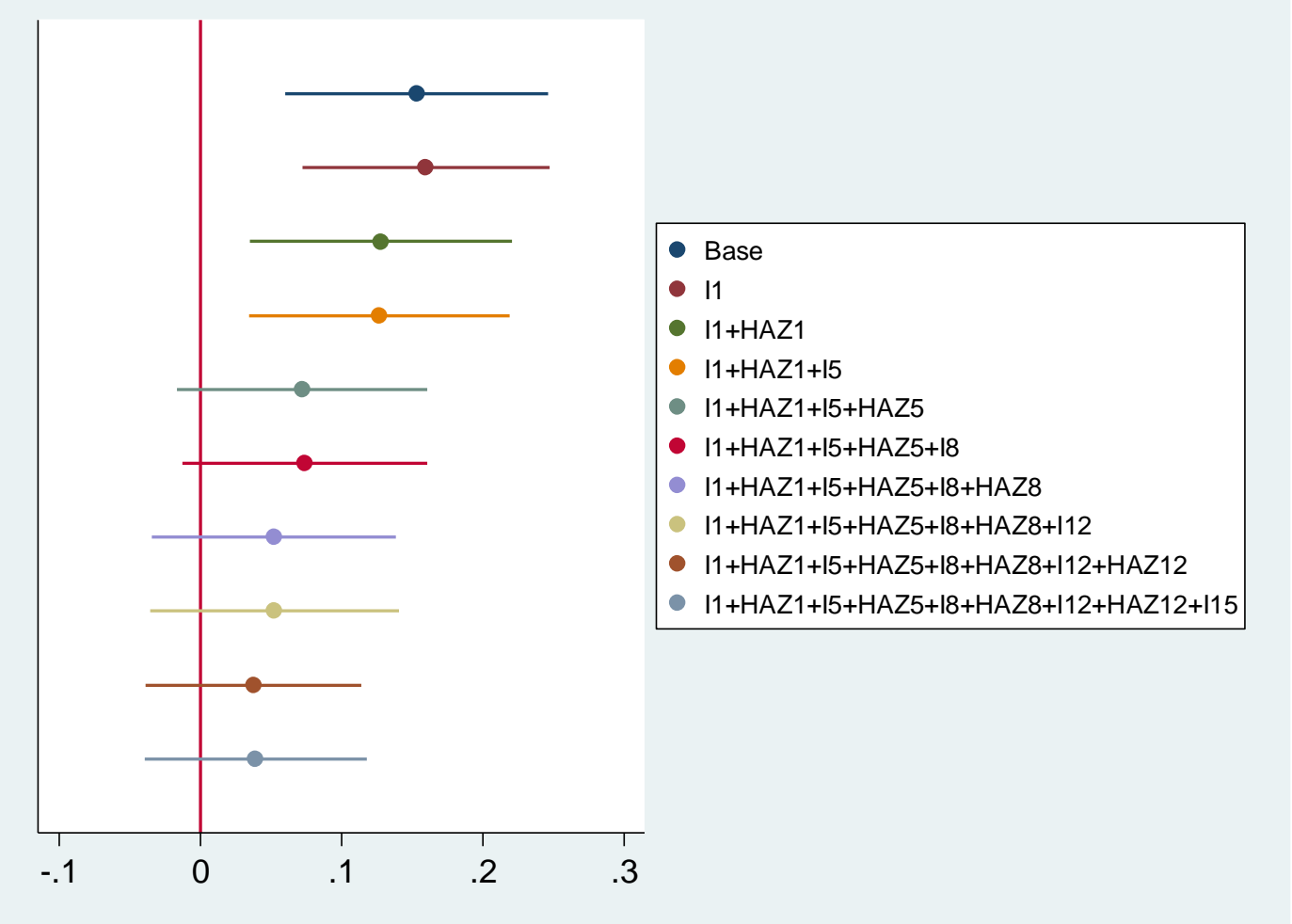

Notes: Figure displays coefficient estimates and associated 95\% confidence intervals. Base denotes the base specification including child gender and age and mother's ethnicity. I\# denotes a specification including controls in the base specification and parental investments on child health at age \# as a mediator. Parental investments on child health at age 1 year are approximated by parental education, household wealth, and urban location; whereas parental investments on child health at all ages above 1 year are measured by expenditure on child's health, child's diversity score and number of meals consumed by the child in last 24 hours. HAZ\# denotes a specification including $\mathrm{HAZ}$ at age \# $\mathrm{y}$ as a mediator. 
Figure 3a: OLS coefficient estimates of the impact of rainfall shocks in the mother's $13^{\text {th }}$ year of life on child HAZ at age $1 \mathrm{y}$ across specifications including mediators in the India, Peru, and Vietnam pooled sample

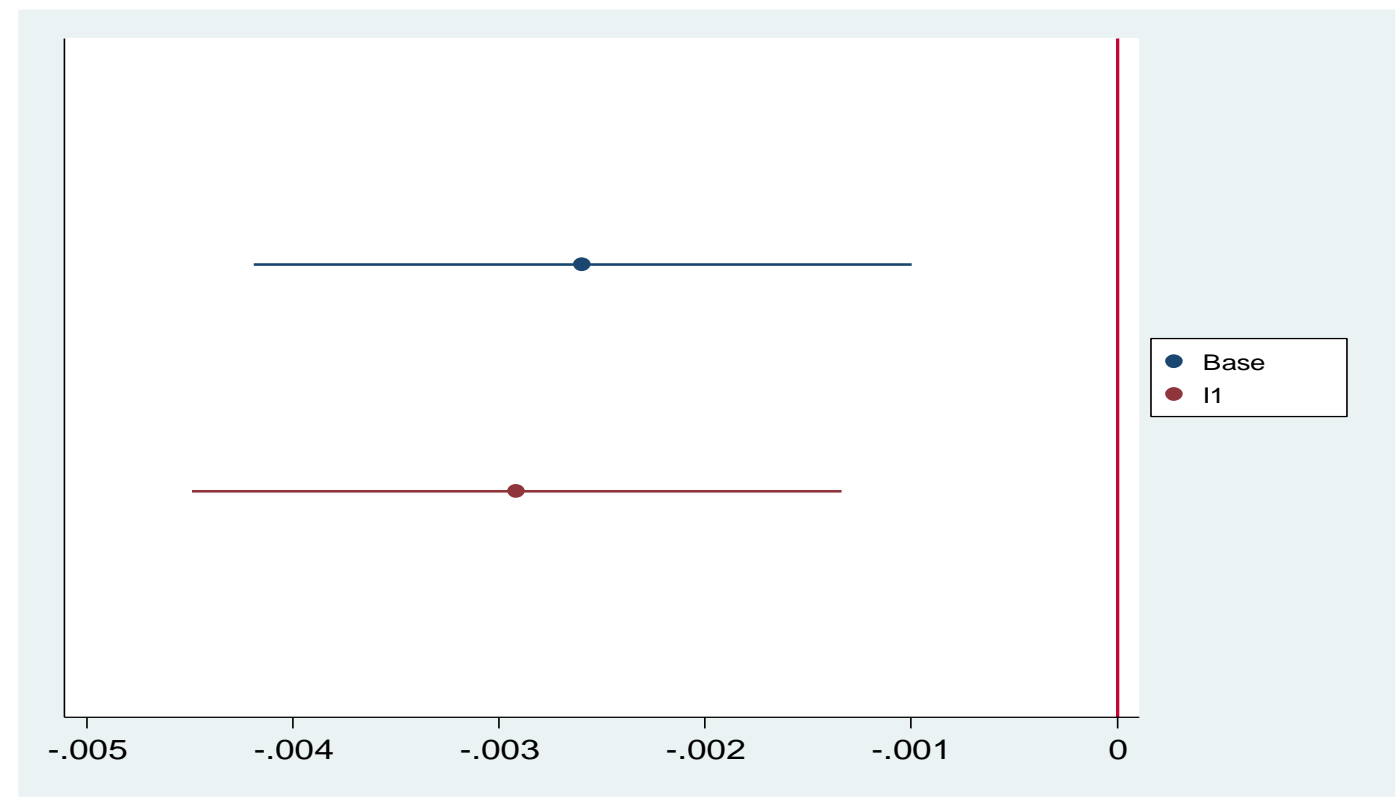

Notes: Figure displays coefficient estimates and associated $95 \%$ confidence intervals. Base denotes the base specification including child gender and age and mother's ethnicity. I1 denotes a specification including controls in the base specification and parental investments on child health at age 1 year as a mediator. Parental investments on child health at age 1 year are approximated by parental education, household wealth, and urban location.

Figure 3b: OLS coefficient estimates of the impact of rainfall shocks in the mother's $13^{\text {th }}$ year of life on child $\mathrm{HAZ}$ at age $5 \mathrm{y}$ across specifications including mediators in the India, Peru, and Vietnam pooled sample

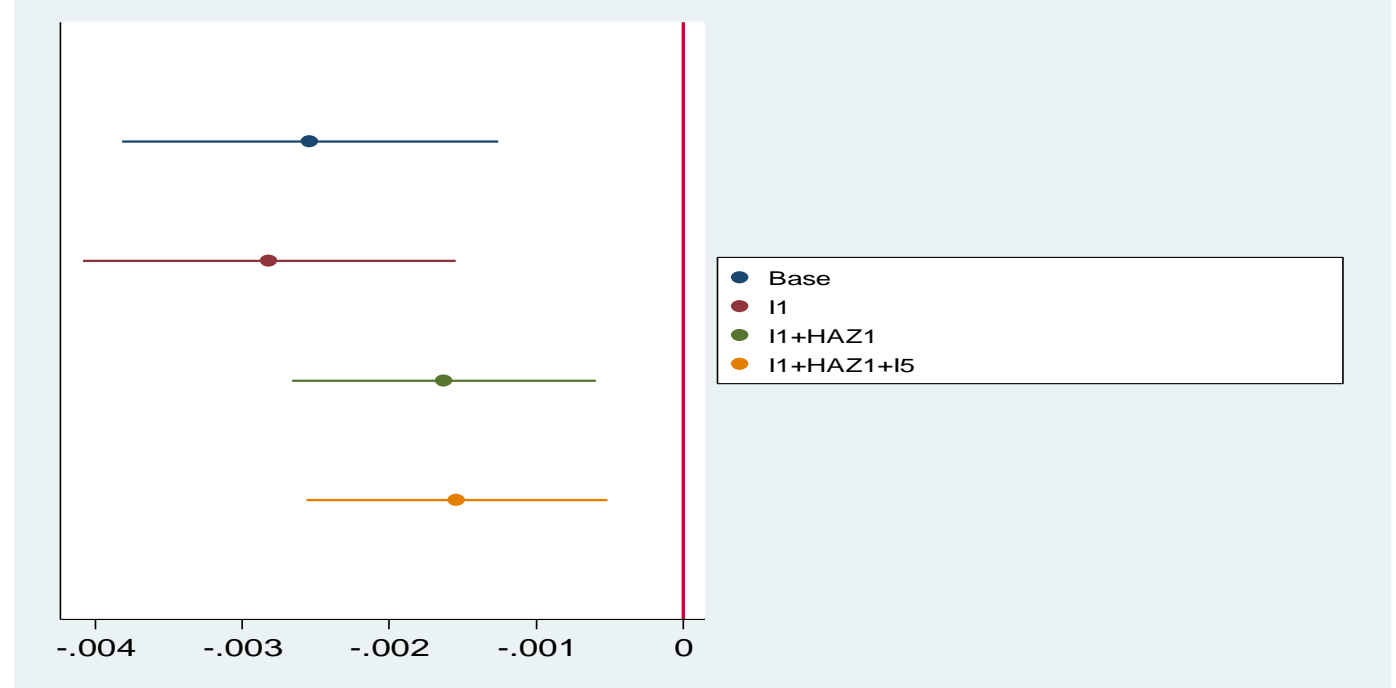

Notes: Figure displays coefficient estimates and associated $95 \%$ confidence intervals. Base denotes the base specification including child gender and age and mother's ethnicity. I\# denotes a specification including controls in the base specification and parental investments on child health at age \# as a mediator. Parental investments on child health at age 1 year are approximated by parental education, household wealth, and urban location; whereas parental investments on child health at all ages above 1 year are measured by expenditure on child's health, child's diversity score and number of meals consumed by the child in last 24 hours. HAZ1 denotes a specification including $\mathrm{HAZ}$ at age $1 \mathrm{y}$ as a mediator. 
Figure 3c: OLS coefficient estimates of the impact of rainfall shocks in the mother's $13^{\text {th }}$ year of life on child $\mathrm{HAZ}$ at age $8 \mathrm{y}$ across specifications including mediators in the India, Peru, and Vietnam pooled sample

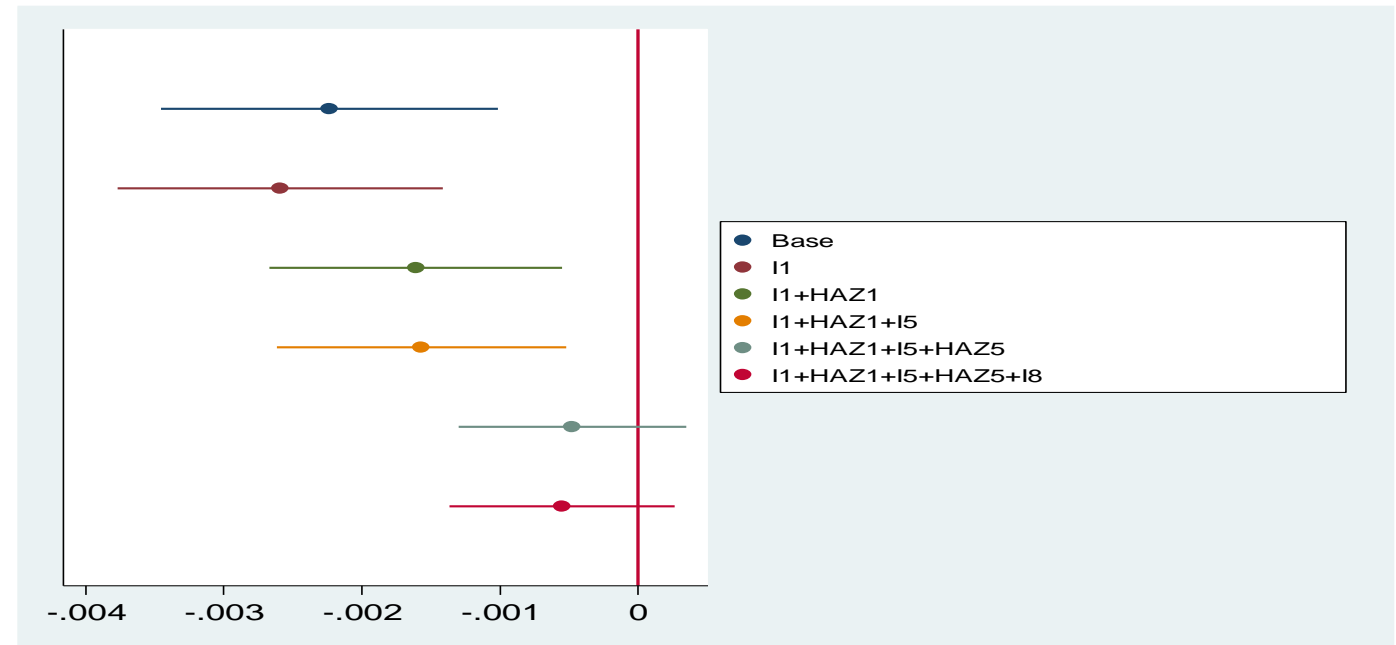

Notes: Figure displays coefficient estimates and associated $95 \%$ confidence intervals. Base denotes the base specification including child gender and age and mother's ethnicity. I\# denotes a specification including controls in the base specification and parental investments on child health at age \# as a mediator. Parental investments on child health at age 1 year are approximated by parental education, household wealth, and urban location; whereas parental investments on child health at all ages above 1 year are measured by expenditure on child's health, child's diversity score and number of meals consumed by the child in last 24 hours. HAZ\# denotes a specification including $\mathrm{HAZ}$ at age \# $\mathrm{y}$ as a mediator.

Figure 3d: OLS coefficient estimates of the impact of rainfall shocks in the mother's $13^{\text {th }}$ year of life on child $\mathrm{HAZ}$ at age $12 \mathrm{y}$ across specifications including mediators in the India, Peru, and Vietnam pooled sample

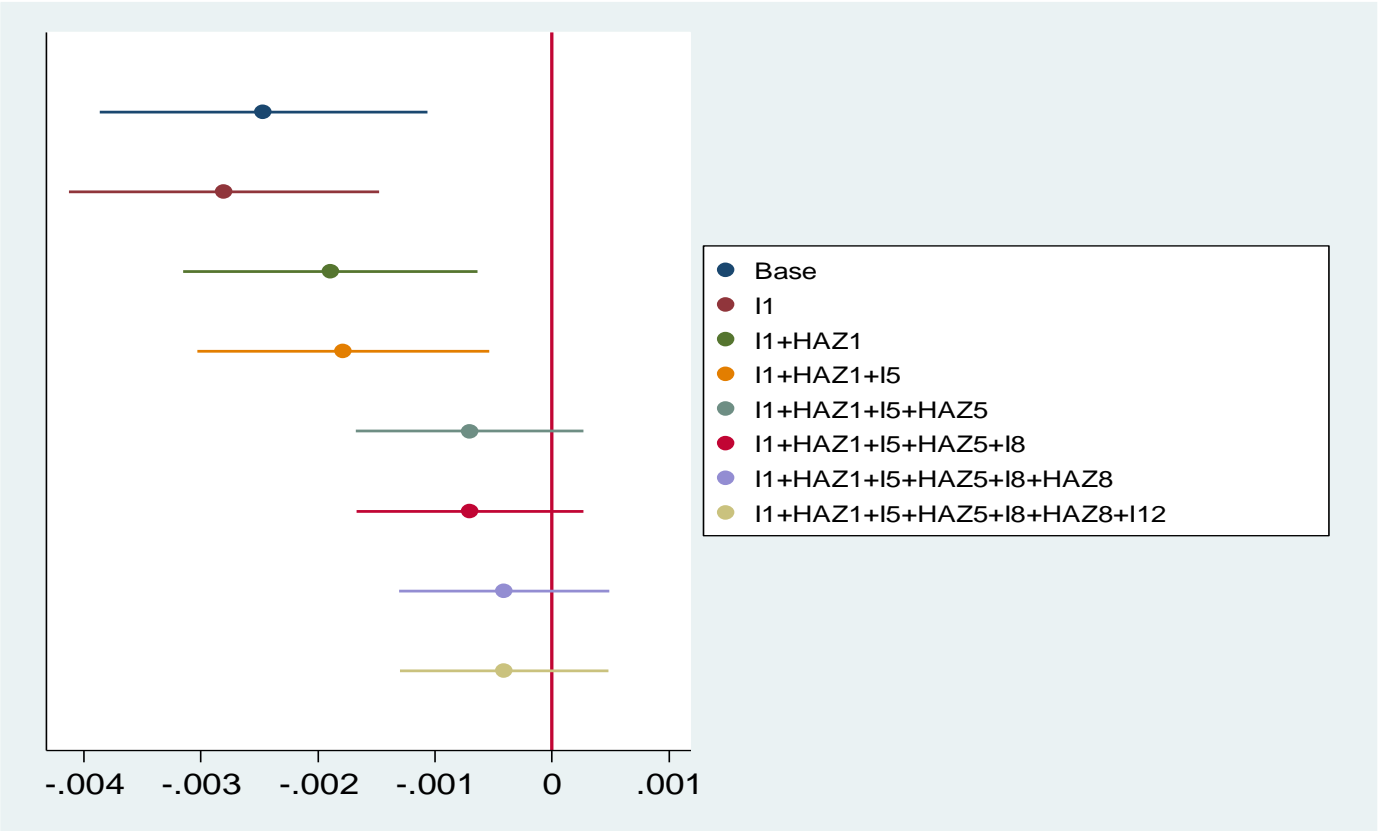

Notes: Figure displays coefficient estimates and associated $95 \%$ confidence intervals. Base denotes the base specification including child gender and age and mother's ethnicity. I\# denotes a specification including controls in the base specification and parental investments on child health at age \# as a mediator. Parental investments on child health at age 1 year are approximated by parental education, household wealth, and urban location; whereas parental investments on child health at all ages above 1 year are measured by expenditure on child's health, child's diversity score and number of meals consumed by the child in last 24 hours. HAZ\# denotes a specification including $\mathrm{HAZ}$ at age \# $\mathrm{y}$ as a mediator. 
Figure 3e: OLS coefficient estimates of the impact of rainfall shocks in the mother's $13^{\text {th }}$ year of life on child $\mathrm{HAZ}$ at age $15 \mathrm{y}$ across specifications including mediators in the India, Peru, and Vietnam pooled sample

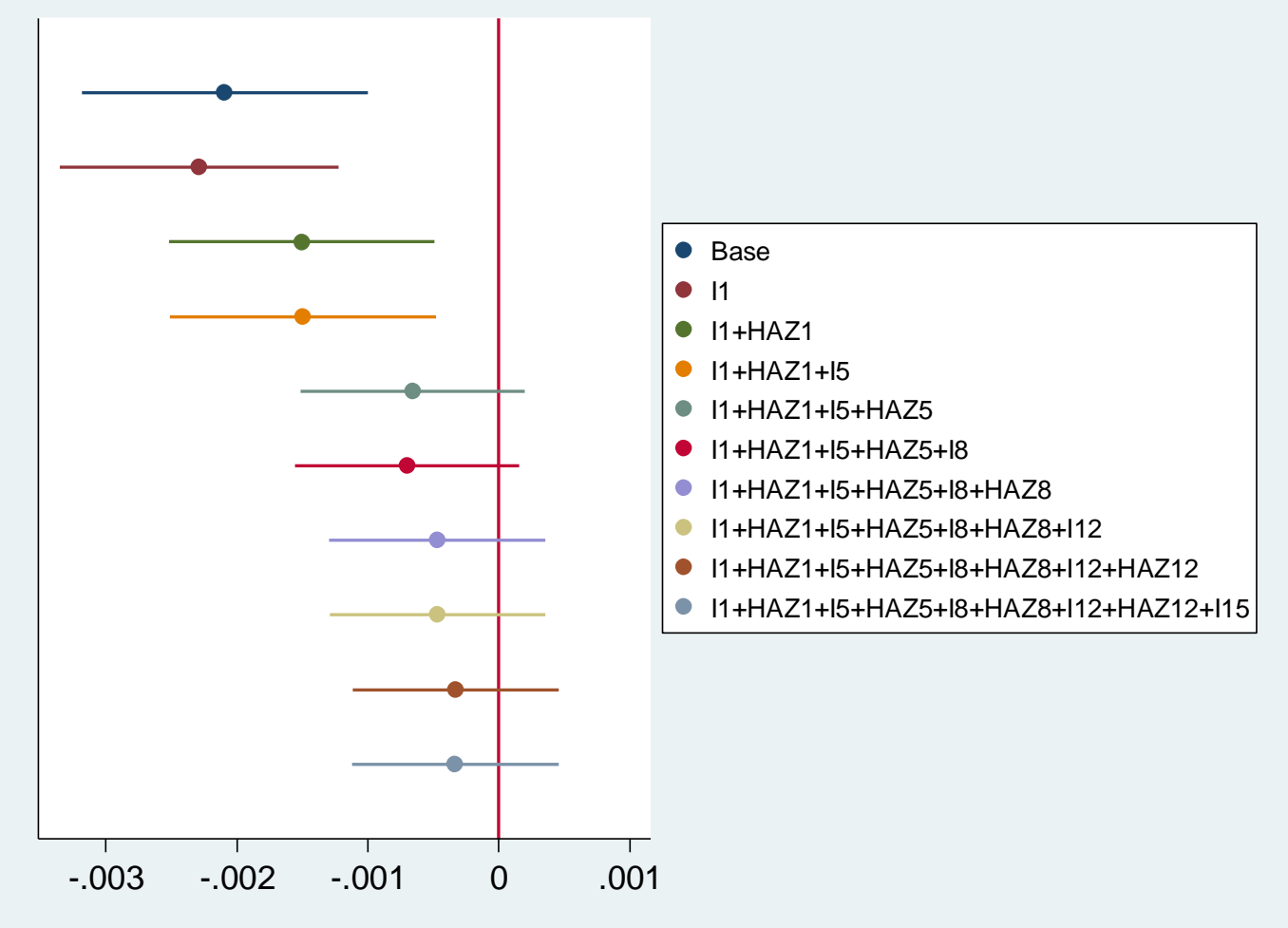

Notes: Figure displays coefficient estimates and associated $95 \%$ confidence intervals. Base denotes the base specification including child gender and age and mother's ethnicity. I\# denotes a specification including controls in the base specification and parental investments on child health at age \# as a mediator. Parental investments on child health at age 1 year are approximated by parental education, household wealth, and urban location; whereas parental investments on child health at all ages above 1 year are measured by expenditure on child's health, child's diversity score and number of meals consumed by the child in last 24 hours. HAZ\# denotes a specification including $\mathrm{HAZ}$ at age \# $\mathrm{y}$ as a mediator. 
Table 1. Descriptive statistics of outcomes and characteristics of Younger Cohort children and their mothers

\begin{tabular}{|c|c|c|c|c|c|}
\hline & Ethiopia & India & Peru & Vietnam & $\begin{array}{c}\text { All } \\
\text { countries }\end{array}$ \\
\hline Mother's adult height (cm) & $\begin{array}{l}158.76 \\
(6.20)\end{array}$ & $\begin{array}{l}151.45 \\
(6.11)\end{array}$ & $\begin{array}{l}149.98 \\
(5.45)\end{array}$ & $\begin{array}{l}152.16 \\
(5.90)\end{array}$ & $\begin{array}{c}152.98 \\
(6.77)\end{array}$ \\
\hline Child height-for-age Z-score (HAZ) 1 y & $\begin{array}{l}-1.49 \\
(1.83)\end{array}$ & $\begin{array}{l}-1.29 \\
(1.48)\end{array}$ & $\begin{array}{l}-1.27 \\
(1.27)\end{array}$ & $\begin{array}{l}-1.13 \\
(1.24)\end{array}$ & $\begin{array}{l}-1.29 \\
(1.47)\end{array}$ \\
\hline Child HAZ 5 y & $\begin{array}{l}-1.44 \\
(1.11)\end{array}$ & $\begin{array}{l}-1.65 \\
(0.99)\end{array}$ & $\begin{array}{l}-1.53 \\
(1.10)\end{array}$ & $\begin{array}{l}-1.36 \\
(1.02)\end{array}$ & $\begin{array}{l}-1.49 \\
(1.06)\end{array}$ \\
\hline Child HAZ 8 y & $\begin{array}{l}-1.19 \\
(1.12)\end{array}$ & $\begin{array}{l}-1.44 \\
(1.04)\end{array}$ & $\begin{array}{l}-1.15 \\
(1.03)\end{array}$ & $\begin{array}{l}-1.11 \\
(1.06)\end{array}$ & $\begin{array}{l}-1.22 \\
(1.07)\end{array}$ \\
\hline Child HAZ 12 y & $\begin{array}{l}-1.45 \\
(0.99)\end{array}$ & $\begin{array}{l}-1.44 \\
(1.03)\end{array}$ & $\begin{array}{l}-1.03 \\
(1.09)\end{array}$ & $\begin{array}{l}-1.05 \\
(1.15)\end{array}$ & $\begin{array}{l}-1.24 \\
(1.09)\end{array}$ \\
\hline Child HAZ 15 y & $\begin{array}{l}-1.35 \\
(1.11)\end{array}$ & $\begin{array}{l}-1.46 \\
(0.97)\end{array}$ & $\begin{array}{l}-1.15 \\
(0.88)\end{array}$ & $\begin{array}{l}-1.02 \\
(0.89)\end{array}$ & $\begin{array}{l}-1.24 \\
(0.98)\end{array}$ \\
\hline Proportion of correct answers in CDA test $5 \mathrm{y}$ & $\begin{array}{c}0.59 \\
(0.21)\end{array}$ & $\begin{array}{c}0.67 \\
(0.18)\end{array}$ & $\begin{array}{c}0.70 \\
(0.18)\end{array}$ & $\begin{array}{c}0.70 \\
(0.18)\end{array}$ & $\begin{array}{c}0.66 \\
(0.19)\end{array}$ \\
\hline Proportion of correct answers in maths test $8 \mathrm{y}$ & $\begin{array}{c}0.23 \\
(0.19)\end{array}$ & $\begin{array}{c}0.42 \\
(0.22)\end{array}$ & $\begin{array}{c}0.49 \\
(0.20)\end{array}$ & $\begin{array}{c}0.66 \\
(0.21)\end{array}$ & $\begin{array}{c}0.45 \\
(0.26)\end{array}$ \\
\hline Proportion of correct answers in maths test $12 \mathrm{y}$ & $\begin{array}{c}0.39 \\
(0.22)\end{array}$ & $\begin{array}{c}0.46 \\
(0.23)\end{array}$ & $\begin{array}{c}0.56 \\
(0.19)\end{array}$ & $\begin{array}{c}0.51 \\
(0.18)\end{array}$ & $\begin{array}{c}0.48 \\
(0.22)\end{array}$ \\
\hline Proportion of correct answers in maths test $15 \mathrm{y}$ & $\begin{array}{c}0.35 \\
(0.17)\end{array}$ & $\begin{array}{c}0.36 \\
(0.17)\end{array}$ & $\begin{array}{c}0.43 \\
(0.18)\end{array}$ & $\begin{array}{c}0.48 \\
(0.22)\end{array}$ & $\begin{array}{c}0.40 \\
(0.20)\end{array}$ \\
\hline Male & $\begin{array}{c}0.53 \\
(0.50)\end{array}$ & $\begin{array}{c}0.54 \\
(0.50)\end{array}$ & $\begin{array}{c}0.50 \\
(0.50)\end{array}$ & $\begin{array}{c}0.51 \\
(0.50)\end{array}$ & $\begin{array}{c}0.52 \\
(0.50)\end{array}$ \\
\hline Age of child (months) in Round 1 & $\begin{array}{l}11.68 \\
(3.57)\end{array}$ & $\begin{array}{l}11.82 \\
(3.48)\end{array}$ & $\begin{array}{l}11.53 \\
(3.52)\end{array}$ & $\begin{array}{l}11.67 \\
(3.16)\end{array}$ & $\begin{array}{l}11.68 \\
(3.43)\end{array}$ \\
\hline Household wealth index $1 \mathrm{y}$ & $\begin{array}{c}0.21 \\
(0.17)\end{array}$ & $\begin{array}{c}0.41 \\
(0.20)\end{array}$ & $\begin{array}{c}0.43 \\
(0.24)\end{array}$ & $\begin{array}{c}0.43 \\
(0.21)\end{array}$ & $\begin{array}{c}0.37 \\
(0.23)\end{array}$ \\
\hline Mother's schooling (years) & $\begin{array}{c}2.89 \\
(3.76)\end{array}$ & $\begin{array}{c}3.65 \\
(4.42)\end{array}$ & $\begin{array}{c}7.85 \\
(4.38)\end{array}$ & $\begin{array}{c}6.76 \\
(4.01)\end{array}$ & $\begin{array}{c}5.29 \\
(4.64)\end{array}$ \\
\hline Father's schooling (years) & $\begin{array}{c}4.85 \\
(4.20)\end{array}$ & $\begin{array}{c}5.59 \\
(5.03)\end{array}$ & $\begin{array}{c}9.08 \\
(3.82)\end{array}$ & $\begin{array}{c}7.59 \\
(3.94)\end{array}$ & $\begin{array}{c}6.78 \\
(4.59)\end{array}$ \\
\hline Urban location $1 \mathrm{y}$ & $\begin{array}{c}0.39 \\
(0.49)\end{array}$ & $\begin{array}{c}0.24 \\
(0.43)\end{array}$ & $\begin{array}{c}0.74 \\
(0.44)\end{array}$ & $\begin{array}{c}0.18 \\
(0.39)\end{array}$ & $\begin{array}{c}0.38 \\
(0.49)\end{array}$ \\
\hline Expenditure on child's health in the last 12 months $5 \mathrm{y}$ & $\begin{array}{c}64.63 \\
(46.67)\end{array}$ & $\begin{array}{c}402.36 \\
(297.83)\end{array}$ & $\begin{array}{c}82.61 \\
(53.84)\end{array}$ & $\begin{array}{c}230.36 \\
(145.56)\end{array}$ & $\begin{array}{c}197.75 \\
(218.68)\end{array}$ \\
\hline Child's dietary diversity score in the last 24 hours $5 \mathrm{y}$ & $\begin{array}{c}4.81 \\
(1.59)\end{array}$ & $\begin{array}{c}5.79 \\
(1.55)\end{array}$ & $\begin{array}{c}7.86 \\
(1.59)\end{array}$ & $\begin{array}{c}6.84 \\
(2.00)\end{array}$ & $\begin{array}{c}6.32 \\
(2.04)\end{array}$ \\
\hline $\begin{array}{l}\text { Number of meals consumed by the child in the last } 24 \text { hours } \\
5 \mathrm{y}\end{array}$ & $\begin{array}{l}4.38 \\
(0.84)\end{array}$ & $\begin{array}{c}5.00 \\
(1.09)\end{array}$ & $\begin{array}{c}4.85 \\
(1.01)\end{array}$ & $\begin{array}{c}4.64 \\
(1.16)\end{array}$ & $\begin{array}{c}4.72 \\
(1.06)\end{array}$ \\
\hline Rainfall shock mother's 10 y (cm) & $\begin{array}{c}0.10 \\
(11.36)\end{array}$ & $\begin{array}{c}-0.27 \\
(13.88)\end{array}$ & $\begin{array}{c}-0.39 \\
(14.57)\end{array}$ & $\begin{array}{c}5.58 \\
(33.06)\end{array}$ & $\begin{array}{c}1.29 \\
(20.47)\end{array}$ \\
\hline Rainfall shock mother's 11 y & $\begin{array}{c}-0.25 \\
(11.09)\end{array}$ & $\begin{array}{c}-0.53 \\
(15.03)\end{array}$ & $\begin{array}{c}0.29 \\
(15.66)\end{array}$ & $\begin{array}{c}0.99 \\
(28.07)\end{array}$ & $\begin{array}{c}0.13 \\
(18.71)\end{array}$ \\
\hline Rainfall shock mother's 12 y & $\begin{array}{c}-0.23 \\
(11.60)\end{array}$ & $\begin{array}{c}-0.18 \\
(15.39)\end{array}$ & $\begin{array}{c}-0.56 \\
(15.12)\end{array}$ & $\begin{array}{c}-0.18 \\
(28.07)\end{array}$ & $\begin{array}{c}-0.29 \\
(18.74)\end{array}$ \\
\hline Rainfall shock mother's 13 y & $\begin{array}{c}0.54 \\
(11.56)\end{array}$ & $\begin{array}{c}-0.99 \\
(15.26)\end{array}$ & $\begin{array}{c}0.21 \\
(15.01)\end{array}$ & $\begin{array}{c}0.28 \\
(28.68)\end{array}$ & $\begin{array}{c}0.01 \\
(18.93)\end{array}$ \\
\hline Rainfall shock mother's 14 y & $\begin{array}{c}-0.09 \\
(12.57)\end{array}$ & $\begin{array}{c}0.03 \\
(16.49)\end{array}$ & $\begin{array}{c}0.35 \\
(16.68)\end{array}$ & $\begin{array}{c}-0.76 \\
(28.25)\end{array}$ & $\begin{array}{c}-0.12 \\
(19.52)\end{array}$ \\
\hline Rainfall shock mother's $15 \mathrm{y}$ & $\begin{array}{c}-0.31 \\
(11.01)\end{array}$ & $\begin{array}{c}-1.04 \\
(13.72)\end{array}$ & $\begin{array}{c}0.83 \\
(17.42)\end{array}$ & $\begin{array}{c}-0.69 \\
(29.62)\end{array}$ & $\begin{array}{c}-0.31 \\
(19.43)\end{array}$ \\
\hline Rainfall shock mother's 16 y & $\begin{array}{c}0.18 \\
(10.32)\end{array}$ & $\begin{array}{c}-0.02 \\
(14.98)\end{array}$ & $\begin{array}{c}0.21 \\
(16.95)\end{array}$ & $\begin{array}{c}-2.35 \\
(30.66)\end{array}$ & $\begin{array}{c}-0.51 \\
(19.90)\end{array}$ \\
\hline Rainfall shock mother's $17 \mathrm{y}$ & $\begin{array}{c}0.30 \\
(11.22)\end{array}$ & $\begin{array}{c}0.46 \\
(14.52)\end{array}$ & $\begin{array}{c}0.31 \\
(16.57)\end{array}$ & $\begin{array}{c}-1.89 \\
(31.41)\end{array}$ & $\begin{array}{c}-0.22 \\
(20.15)\end{array}$ \\
\hline Rainfall shock mother's 18 y & $\begin{array}{c}-0.05 \\
(10.02)\end{array}$ & $\begin{array}{c}-0.11 \\
(14.59)\end{array}$ & $\begin{array}{c}0.63 \\
(16.07)\end{array}$ & $\begin{array}{c}-1.22 \\
(32.33)\end{array}$ & $\begin{array}{c}-0.20 \\
(20.26)\end{array}$ \\
\hline
\end{tabular}


Notes: Statistics are means with standard deviations in parentheses. The sample is restricted to children with nonmissing or no extreme values in height-for-age Z-scores (greater than 6 in absolute value) in all rounds or nonmissing test scores in all rounds. Expenditure on child's health in the last 12 months is measured in country currency and includes expenditure on medical consultation, treatment, and medication. The dietary diversity score is the number of different food groups consumed by the child in the last 24 hours, out of 17 groups in total. Rainfall shocks at each period are deviations from the community and season combined average and year-specific average, calculated by aggregating, over the period, the residuals from a regression of the level of distance-weighted monthly total precipitation on combined community and calendar month fixed effects and year fixed effects for the period between 1950-2014 using the Global Climate Database of the University of Delaware (Willmott and Matsuura 2012). Community rainfall shocks are measured in centimetres. 
Table 2. OLS estimates of associations of maternal adult height with child height-for-age $Z$ scores (HAZ) from age 1 to $15 \mathrm{y}$

\begin{tabular}{|c|c|c|c|c|c|}
\hline & \multicolumn{5}{|c|}{ Ethiopia } \\
\hline & HAZ 1 y & HAZ 5 y & HAZ 8 y & HAZ 12 y & HAZ 15 y \\
\hline Mother's adult & $0.034 * * *$ & $0.047 * * *$ & $0.040 * * *$ & $0.035 * * *$ & $0.044 * * *$ \\
\hline height & $(0.011)$ & $(0.006)$ & $(0.004)$ & $(0.004)$ & $(0.005)$ \\
\hline \multirow[t]{2}{*}{ Male } & $-0.389 * * *$ & $-0.102 *$ & $-0.145 * * *$ & 0.024 & $-0.822 * * *$ \\
\hline & $(0.098)$ & $(0.051)$ & $(0.050)$ & $(0.065)$ & $(0.078)$ \\
\hline \multirow[t]{2}{*}{ Child's age } & $-0.122 * * *$ & $-0.018 * *$ & -0.001 & -0.006 & $0.016 * *$ \\
\hline & $(0.018)$ & $(0.008)$ & $(0.005)$ & $(0.006)$ & $(0.007)$ \\
\hline R-squared & 0.117 & 0.093 & 0.068 & 0.069 & 0.219 \\
\hline \multirow[t]{2}{*}{ Observations } & 1622 & 1622 & 1622 & 1622 & 1622 \\
\hline & \multicolumn{5}{|c|}{ India } \\
\hline Mother's adult & $0.053^{* * *}$ & $0.044 * * *$ & $0.044 * * *$ & $0.045^{* * *}$ & $0.049 * * *$ \\
\hline height & $(0.006)$ & $(0.004)$ & $(0.004)$ & $(0.005)$ & $(0.004)$ \\
\hline \multirow[t]{2}{*}{ Male } & $-0.181 * * *$ & $-0.116^{* *}$ & -0.072 & 0.015 & 0.010 \\
\hline & $(0.058)$ & $(0.044)$ & $(0.046)$ & $(0.046)$ & $(0.050)$ \\
\hline \multirow[t]{2}{*}{ Child's age } & $-0.085^{* * *}$ & 0.006 & -0.003 & -0.005 & 0.001 \\
\hline & $(0.011)$ & $(0.008)$ & $(0.008)$ & $(0.007)$ & $(0.007)$ \\
\hline R-squared & 0.111 & 0.101 & 0.111 & 0.107 & 0.130 \\
\hline \multirow[t]{2}{*}{ Observations } & 1803 & 1803 & 1803 & 1803 & 1803 \\
\hline & \multicolumn{5}{|c|}{ Peru } \\
\hline \multirow{2}{*}{$\begin{array}{l}\text { Mother's adult } \\
\text { height }\end{array}$} & $0.069 * * *$ & $0.079 * * *$ & $0.080 * * *$ & $0.078 * * *$ & $0.070 * * *$ \\
\hline & $(0.007)$ & $(0.005)$ & $(0.004)$ & $(0.005)$ & $(0.003)$ \\
\hline \multirow[t]{2}{*}{ Male } & $-0.165^{* *}$ & 0.050 & 0.020 & $0.085^{*}$ & $0.280 * * *$ \\
\hline & $(0.064)$ & $(0.044)$ & $(0.043)$ & $(0.045)$ & $(0.058)$ \\
\hline \multirow[t]{2}{*}{ Child's age } & $-0.083 * * *$ & $0.051 * * *$ & -0.003 & $-0.015^{*}$ & -0.010 \\
\hline & $(0.007)$ & $(0.011)$ & $(0.007)$ & $(0.008)$ & $(0.008)$ \\
\hline R-squared & 0.187 & 0.273 & 0.227 & 0.195 & 0.237 \\
\hline \multirow[t]{2}{*}{ Observations } & 1751 & 1751 & 1751 & 1751 & 1751 \\
\hline & \multicolumn{5}{|c|}{ Vietnam } \\
\hline \multirow{2}{*}{$\begin{array}{l}\text { Mother's adult } \\
\text { height }\end{array}$} & $0.048 * * *$ & $0.055 * * *$ & $0.051 * * *$ & $0.050 * * *$ & $0.054 * * *$ \\
\hline & $(0.005)$ & $(0.004)$ & $(0.005)$ & $(0.005)$ & $(0.004)$ \\
\hline \multirow[t]{2}{*}{ Male } & $-0.155^{* *}$ & 0.023 & -0.039 & 0.050 & $0.087^{*}$ \\
\hline & $(0.057)$ & $(0.042)$ & $(0.045)$ & $(0.058)$ & $(0.045)$ \\
\hline \multirow[t]{2}{*}{ Child's age } & $-0.109 * * *$ & -0.002 & -0.013 & -0.012 & -0.006 \\
\hline & $(0.013)$ & (0.009) & $(0.008)$ & $(0.007)$ & $(0.006)$ \\
\hline R-squared & 0.249 & 0.236 & 0.205 & 0.220 & 0.220 \\
\hline \multirow[t]{2}{*}{ Observations } & 1829 & 1829 & 1829 & 1829 & 1829 \\
\hline & \multicolumn{5}{|c|}{ All countries } \\
\hline \multirow{2}{*}{$\begin{array}{l}\text { Mother's adult } \\
\text { height }\end{array}$} & $0.051 * * *$ & $0.056 * * *$ & $0.053 * * *$ & $0.051 * * *$ & $0.052 * * *$ \\
\hline & $(0.004)$ & $(0.003)$ & $(0.003)$ & $(0.003)$ & $(0.002)$ \\
\hline \multirow[t]{2}{*}{ Male } & $-0.219 * * *$ & -0.037 & $-0.061 * *$ & 0.039 & $-0.097 *$ \\
\hline & $(0.036)$ & $(0.024)$ & $(0.023)$ & $(0.026)$ & $(0.053)$ \\
\hline \multirow[t]{2}{*}{ Child's age } & $-0.099 * * *$ & $0.017 * * *$ & -0.005 & $-0.011 * * *$ & -0.001 \\
\hline & $(0.007)$ & $(0.006)$ & $(0.004)$ & $(0.004)$ & $(0.004)$ \\
\hline R-squared & 0.149 & 0.165 & 0.153 & 0.173 & 0.176 \\
\hline Observations & 7005 & 7005 & 7005 & 7005 & 7005 \\
\hline
\end{tabular}

Notes: Standard errors clustered at the sentinel site are in parentheses. ${ }^{* * *}$ significant at $1 \%$, $* *$ significant at $5 \%$, * significant at $10 \%$. Child's age is measured in months at the time the HAZ score measure is collected. All specifications control for mother's ethnicity, but estimates are not reported. 
Table 3. OLS estimates of the impact of rainfall shocks at different periods of mother's adolescence on maternal adult height

\begin{tabular}{|c|c|c|c|c|c|}
\hline & Ethiopia & India & Peru & Vietnam & All countries \\
\hline \multirow[t]{4}{*}{ Rainfall shock $10 \mathrm{y}$} & 0.0003 & -0.0069 & $-0.0247 *$ & -0.0078 & -0.0061 \\
\hline & $(0.0160)$ & $(0.0126)$ & $(0.0136)$ & $(0.0056)$ & $(0.0040)$ \\
\hline & {$[1.000]$} & {$[1.000]$} & [0.693] & {$[1.000]$} & {$[1.000]$} \\
\hline & $\{0.985\}$ & $\{0.496\}$ & $\{0.006\} * * *$ & $\{0.055\}^{*}$ & $\{0.055\}^{*}$ \\
\hline \multirow{4}{*}{ Rainfall shock 11 y } & -0.0261 & -0.0086 & -0.0124 & $0.0123 * *$ & 0.0010 \\
\hline & $(0.0174)$ & $(0.0110)$ & $(0.0116)$ & $(0.0054)$ & $(0.0040)$ \\
\hline & {$[1.000]$} & {$[1.000]$} & {$[1.000]$} & {$[0.244]$} & {$[1.000]$} \\
\hline & $\{0.061\}^{*}$ & $\{0.356\}$ & $\{0.126\}$ & $\{0.013\} * * *$ & $\{0.769\}$ \\
\hline \multirow[t]{4}{*}{ Rainfall shock 12 y } & -0.0048 & -0.0124 & -0.0148 & -0.0003 & -0.0055 \\
\hline & $(0.0148)$ & $(0.0106)$ & $(0.0116)$ & $(0.0048)$ & $(0.0038)$ \\
\hline & {$[1.000]$} & {$[1.000]$} & {$[1.000]$} & {$[1.000]$} & {$[1.000]$} \\
\hline & $\{0.730\}$ & $\{0.204\}$ & $\{0.083\}^{*}$ & $\{0.940\}$ & $\{0.137\}$ \\
\hline \multirow{4}{*}{ Rainfall shock 13 y } & $0.0278 * *$ & -0.0190 & $-0.0306 * * *$ & $-0.0099 * *$ & $-0.0127 * * *$ \\
\hline & $(0.0126)$ & $(0.0123)$ & $(0.0117)$ & $(0.0048)$ & $(0.0038)$ \\
\hline & {$[0.287]$} & {$[1.000]$} & {$[0.091]^{*}$} & {$[0.390]$} & {$[0.008]^{* * *}$} \\
\hline & $\{0.029\} * *$ & $\{0.038\} * *$ & $\{0.000\} * * *$ & $\{0.033\} * *$ & $\{0.002\} * * *$ \\
\hline \multirow[t]{4}{*}{ Rainfall shock 14 y } & $0.0418 * *$ & $-0.0289 * * *$ & 0.0020 & -0.0057 & $-0.0081 * *$ \\
\hline & $(0.0170)$ & $(0.0103)$ & $(0.0085)$ & $(0.0048)$ & $(0.0035)$ \\
\hline & {$[0.150]$} & {$[0.05]^{* *}$} & {$[1.000]$} & {$[1.000]$} & [0.219] \\
\hline & $\{0.000\} * * *$ & $\{0.001\}$ *** & $\{0.813\}$ & $\{0.243\}$ & $\{0.027\} * *$ \\
\hline \multirow[t]{4}{*}{ Rainfall shock $15 \mathrm{y}$} & $0.0522 * * *$ & -0.0048 & -0.0009 & -0.0003 & -0.0003 \\
\hline & $(0.0148)$ & $(0.0117)$ & $(0.0103)$ & $(0.0043)$ & $(0.0034)$ \\
\hline & {$[0.005]^{* * *}$} & {$[1.000]$} & {$[1.000]$} & {$[1.000]$} & {$[1.000]$} \\
\hline & $\{0.000\} * * *$ & $\{0.639\}$ & $\{0.901\}$ & $\{0.946\}$ & $\{0.928\}$ \\
\hline \multirow[t]{4}{*}{ Rainfall shock 16 y } & $0.0454 * *$ & -0.0007 & $0.0164 *$ & $-0.0091 * *$ & -0.0029 \\
\hline & $(0.0179)$ & $(0.0101)$ & $(0.0089)$ & $(0.0044)$ & $(0.0033)$ \\
\hline & {$[0.121]$} & {$[1.000]$} & {$[0.653]$} & {$[0.386]$} & {$[1.000]$} \\
\hline & $\{0.001\} * * *$ & $\{0.934\}$ & $\{0.029\} * *$ & $\{0.031\} * *$ & $\{0.396\}$ \\
\hline \multirow[t]{4}{*}{ Rainfall shock 17 y } & $0.0048 * * *$ & 0.0013 & 0.0010 & -0.0007 & -0.0003 \\
\hline & $(0.0016)$ & $(0.0011)$ & $(0.0009)$ & $(0.0005)$ & $(0.0003)$ \\
\hline & {$[0.008]^{* * *}$} & {$[1.000]$} & {$[1.000]$} & [1.000] & {$[1.000]$} \\
\hline & $\{0.000\} * * *$ & $\{0.161\}$ & $\{0.186\}$ & $\{0.111\}$ & $\{0.383\}$ \\
\hline \multirow[t]{4}{*}{ Rainfall shock 18 y } & $0.0378 * *$ & -0.0002 & 0.0009 & 0.0049 & -0.0007 \\
\hline & $(0.0150)$ & $(0.0112)$ & $(0.0078)$ & $(0.0035)$ & $(0.0033)$ \\
\hline & {$[0.130]$} & {$[1.000]$} & {$[1.000]$} & {$[1.000]$} & {$[1.000]$} \\
\hline & $\{0.015\}^{* *}$ & $\{0.979\}$ & $\{0.919\}$ & $\{0.210\}$ & $\{0.828\}$ \\
\hline \multirow[t]{4}{*}{ Rainfall shock 19 y } & $0.0316^{* *}$ & 0.0021 & 0.0092 & -0.0053 & -0.0019 \\
\hline & $(0.0130)$ & $(0.0131)$ & $(0.0095)$ & $(0.0045)$ & $(0.0035)$ \\
\hline & [0.161] & [1.000] & [1.000] & [1.000] & [1.000] \\
\hline & $\{0.022\}^{* *}$ & $\{0.802\}$ & $\{0.265\}$ & $\{0.213\}$ & $\{0.603\}$ \\
\hline R-squared & 0.032 & 0.038 & 0.040 & 0.076 & 0.245 \\
\hline $\begin{array}{l}\text { Kleibergen-Paap F- } \\
\text { statistic }\end{array}$ & 2.90 & 1.01 & 2.03 & 2.43 & 2.88 \\
\hline Observations & 1622 & 1803 & 1751 & 1829 & 7005 \\
\hline
\end{tabular}

Notes: Standard errors clustered at the community the mother was residing in the calendar year she turned 10 years old are in parentheses. Bonferroni multiple testing corrected p-values are in squared brackets. P-values computed through 1000 random permutations of the values of rainfall shocks at each period of mother's life in curly brackets. $* * *$ significant at $1 \%, * *$ significant at $5 \%, *$ significant at $10 \%$. Controls included in all specifications for child age in Round 1, child gender, and mother's ethnicity, but coefficients are not reported. 
Table 4. OLS and TSLS estimates of the impact of maternal adolescent nutrition on child nutritional status from age 1 to $15 \mathrm{y}$ in the India, Peru, and Vietnam pooled sample

\begin{tabular}{|c|c|c|c|c|c|}
\hline & \multicolumn{5}{|c|}{ OLS } \\
\hline & HAZ 1 y & HAZ 5 y & HAZ 8 y & HAZ 12 y & HAZ 15 y \\
\hline Mother's adult & $0.057 * * *$ & $0.060 * * *$ & $0.058 * * *$ & $0.057 * * *$ & $0.057 * * *$ \\
\hline height & $(0.004)$ & $(0.003)$ & $(0.003)$ & $(0.003)$ & $(0.002)$ \\
\hline \multirow[t]{2}{*}{ Male } & $-0.165 * * *$ & -0.015 & -0.034 & 0.045 & $0.121 * * *$ \\
\hline & $(0.034)$ & $(0.026)$ & $(0.026)$ & $(0.028)$ & $(0.032)$ \\
\hline \multirow[t]{2}{*}{ Child's age } & $-0.092 * * *$ & $0.026 * * *$ & -0.006 & $-0.012 * * *$ & -0.006 \\
\hline & $(0.006)$ & $(0.007)$ & $(0.004)$ & $(0.004)$ & $(0.004)$ \\
\hline R-squared & 0.165 & 0.197 & 0.184 & 0.188 & 0.214 \\
\hline \multirow[t]{2}{*}{ Observations } & 5383 & 5383 & 5383 & 5383 & 5383 \\
\hline & \multicolumn{5}{|c|}{ TSLS } \\
\hline Mother's adult & $0.188 * *$ & $0.181 * * *$ & $0.164 * * *$ & $0.182 * *$ & $0.153 * * *$ \\
\hline height & $(0.085)$ & $(0.063)$ & $(0.062)$ & $(0.072)$ & $(0.048)$ \\
\hline \multirow[t]{2}{*}{ Male } & $-0.137 * * *$ & 0.012 & -0.011 & $0.072 * *$ & $0.141 * * *$ \\
\hline & $(0.040)$ & $(0.031)$ & $(0.029)$ & $(0.033)$ & $(0.036)$ \\
\hline \multirow[t]{2}{*}{ Child's age } & $-0.089 * * *$ & $0.021 * * *$ & -0.003 & -0.006 & -0.002 \\
\hline & $(0.008)$ & $(0.007)$ & $(0.005)$ & $(0.006)$ & $(0.005)$ \\
\hline Kleibergen-Paap & 14.44 & 14.30 & 13.98 & 13.92 & 14 \\
\hline $\begin{array}{l}\text { F-statistic } \\
\text { Observations }\end{array}$ & 5383 & 5383 & 5383 & 5383 & 5202 \\
\hline Ubservations & & & & 5383 & 5383 \\
\hline
\end{tabular}

Notes: Standard errors clustered at the sentinel site are in parentheses. *** significant at 1\%, ** significant at 5\%, * significant at $10 \%$. The sample is restricted to children with non-missing or no extreme values in height-for-age Z-scores (greater than 6 in absolute value) in all rounds in India, Peru, and Vietnam. Child's age is measured in months at the time the HAZ score measure is collected. TSLS estimation is using rainfall in the calendar year the mother completed her $13^{\text {th }}$ year of age as an instrument for mother's adult height. All specifications control for mother's ethnicity, but estimates are not reported. 
Table 5. OLS and TSLS estimates of the impact of mother's adolescence nutrition on child quantitative achievement scores from age 5 to $15 \mathrm{y}$ in the India, Peru, and Vietnam pooled sample

\begin{tabular}{lcccc}
\hline \hline & & \multicolumn{3}{c}{ OLS } \\
& Score 5 y & Score 8 y & Score 12 y & Score 15 y \\
\hline Mother's adult & $0.005^{*}$ & $0.014 * * *$ & $0.010^{* * *}$ & $0.011^{* * *}$ \\
height & $(0.003)$ & $(0.003)$ & $(0.003)$ & $(0.003)$ \\
Male & -0.014 & 0.046 & -0.002 & $0.078 * *$ \\
& $(0.029)$ & $(0.029)$ & $(0.027)$ & $(0.034)$ \\
R-squared & 0.067 & 0.060 & 0.057 & 0.027 \\
Observations & 4857 & 4857 & 4857 & 4857 \\
\hline & & & TSLS & \\
\hline Mother's adult & 0.024 & 0.078 & -0.078 & 0.026 \\
height & $(0.077)$ & $(0.062)$ & $(0.067)$ & $(0.068)$ \\
Male & -0.012 & $0.057 *$ & -0.017 & $0.081 * *$ \\
& $(0.034)$ & $(0.033)$ & $(0.029)$ & $(0.032)$ \\
Kleibergen-Paap & 12.14 & 11.70 & 10.56 & 10.56 \\
F-statistic & 4857 & 4857 & 4857 & 4857 \\
Observations & & & & \\
\hline
\end{tabular}

Notes: Standard errors clustered at the sentinel site are in parentheses. *** significant at $1 \%$, ** significant at $5 \%$, * significant at $10 \%$. Dependent variables are age-normalised test scores. TSLS estimation is using rainfall in the calendar year the mother completed her $13^{\text {th }}$ year of age as an instrument for mother's adult height. All specifications include controls for mother's ethnicity, the language of administration of the test, and whether the test was administered in the child's mother tongue, but estimates are not reported. 
Table 6. OLS estimates of the impact of rainfall shocks in the mother's $13^{\text {th }}$ year of life on child nutritional status from age 1 to $15 \mathrm{y}$ in the India, Peru, and Vietnam pooled sample and by country

\begin{tabular}{|c|c|c|c|c|c|}
\hline & \multicolumn{5}{|c|}{ Pooled Sample (India, Peru, and Vietnam) } \\
\hline & HAZ 1 y & HAZ 5 y & HAZ 8 y & HAZ 12 y & HAZ 15 y \\
\hline Rainfall shock & $-0.0026 * * *$ & $-0.0025 * * *$ & $-0.0022 * * *$ & $-0.0025 * * *$ & $-0.0021 * * *$ \\
\hline mother's $13 \mathrm{y}$ & $(0.0008)$ & $(0.0007)$ & $(0.0006)$ & $(0.0007)$ & $(0.0006)$ \\
\hline \multirow[t]{2}{*}{ Male } & $-0.178 * * *$ & -0.029 & -0.046 & 0.033 & $0.109 * * *$ \\
\hline & $(0.033)$ & $(0.028)$ & $(0.028)$ & $(0.027)$ & $(0.028)$ \\
\hline \multirow[t]{2}{*}{ Child's age } & $-0.093 * * *$ & $0.029 * * *$ & $-0.008^{*}$ & $-0.014 * * *$ & $-0.007 *$ \\
\hline & $(0.006)$ & $(0.004)$ & $(0.004)$ & $(0.005)$ & $(0.004)$ \\
\hline R-squared & 0.108 & 0.093 & 0.089 & 0.105 & 0.095 \\
\hline \multirow[t]{2}{*}{ Observations } & 5383 & 5383 & 5383 & 5383 & 5383 \\
\hline & \multicolumn{5}{|c|}{ Ethiopia } \\
\hline \multirow{2}{*}{$\begin{array}{l}\text { Rainfall shock } \\
\text { mother's } 13 \text { y }\end{array}$} & 0.0005 & 0.0015 & 0.0017 & 0.0006 & $0.0040 *$ \\
\hline & $(0.0041)$ & $(0.0030)$ & $(0.0024)$ & $(0.0024)$ & $(0.0022)$ \\
\hline \multirow[t]{2}{*}{ Male } & $-0.379 * * *$ & $-0.089 *$ & $-0.133 * * *$ & 0.035 & $-0.810 * * *$ \\
\hline & $(0.097)$ & $(0.049)$ & $(0.048)$ & $(0.057)$ & $(0.055)$ \\
\hline \multirow[t]{2}{*}{ Child's age } & $-0.120 * * *$ & $-0.016^{* *}$ & 0.002 & -0.003 & $0.019 * * *$ \\
\hline & $(0.016)$ & $(0.008)$ & $(0.007)$ & $(0.005)$ & $(0.006)$ \\
\hline R-squared & 0.104 & 0.024 & 0.019 & 0.021 & 0.162 \\
\hline \multirow[t]{2}{*}{ Observations } & 1622 & 1622 & 1622 & 1622 & 1622 \\
\hline & \multicolumn{5}{|c|}{ India } \\
\hline $\begin{array}{l}\text { Rainfall shock } \\
\text { mother's } 13 \text { y }\end{array}$ & $\begin{array}{l}-0.0043^{*} \\
(0.0022)\end{array}$ & $\begin{array}{c}0.0011 \\
(0.0014)\end{array}$ & $\begin{array}{c}0.0013 \\
(0.0016)\end{array}$ & $\begin{array}{c}0.0015 \\
(0.0016)\end{array}$ & $\begin{array}{l}-0.0002 \\
(0.0015)\end{array}$ \\
\hline \multirow[t]{2}{*}{ Male } & $-0.181 * * *$ & $-0.114 * *$ & -0.070 & 0.016 & 0.012 \\
\hline & $(0.062)$ & $(0.045)$ & $(0.050)$ & $(0.045)$ & $(0.045)$ \\
\hline \multirow[t]{2}{*}{ Child's age } & $-0.085 * * *$ & 0.006 & -0.004 & -0.006 & -0.001 \\
\hline & $(0.010)$ & $(0.007)$ & $(0.008)$ & $(0.008)$ & $(0.008)$ \\
\hline R-squared & 0.069 & 0.029 & 0.047 & 0.039 & 0.040 \\
\hline \multirow[t]{2}{*}{ Observations } & 1803 & 1803 & 1803 & 1803 & 1803 \\
\hline & \multicolumn{5}{|c|}{ Peru } \\
\hline \multirow{2}{*}{$\begin{array}{l}\text { Rainfall shock } \\
\text { mother's } 13 \text { y }\end{array}$} & -0.0024 & $-0.0028 *$ & $-0.0046 * * *$ & $-0.0039 * *$ & $-0.0020 *$ \\
\hline & $(0.0021)$ & $(0.0017)$ & $(0.0015)$ & $(0.0017)$ & $(0.0011)$ \\
\hline \multirow[t]{2}{*}{ Male } & $-0.208 * * *$ & 0.001 & -0.025 & 0.041 & $0.239 * * *$ \\
\hline & $(0.060)$ & $(0.051)$ & $(0.047)$ & $(0.046)$ & $(0.046)$ \\
\hline \multirow[t]{2}{*}{ Child's age } & $-0.085 * * *$ & $0.059 * * *$ & -0.005 & $-0.018 * *$ & $-0.011 *$ \\
\hline & $(0.007)$ & $(0.006)$ & $(0.007)$ & $(0.008)$ & $(0.006)$ \\
\hline R-squared & 0.108 & 0.129 & 0.064 & 0.054 & 0.056 \\
\hline \multirow[t]{2}{*}{ Observations } & 1751 & 1751 & 1751 & 1751 & 1751 \\
\hline & \multicolumn{5}{|c|}{ Vietnam } \\
\hline \multirow{2}{*}{$\begin{array}{l}\text { Rainfall shock } \\
\text { mother's } 13 \text { y }\end{array}$} & -0.0013 & $-0.0026 * * *$ & $-0.0020 * * *$ & $-0.0026 * * *$ & $-0.0025 * * *$ \\
\hline & $(0.0009)$ & $(0.0008)$ & $(0.0007)$ & $(0.0009)$ & $(0.0007)$ \\
\hline \multirow[t]{2}{*}{ Male } & $-0.166^{* * *}$ & 0.010 & -0.051 & 0.039 & $0.074 *$ \\
\hline & $(0.051)$ & $(0.044)$ & $(0.045)$ & $(0.050)$ & $(0.042)$ \\
\hline \multirow[t]{2}{*}{ Child's age } & $-0.111 * * *$ & -0.004 & $-0.015^{* *}$ & $-0.014 * *$ & -0.008 \\
\hline & $(0.010)$ & $(0.006)$ & $(0.007)$ & $(0.006)$ & $(0.005)$ \\
\hline R-squared & 0.201 & 0.147 & 0.132 & 0.161 & 0.105 \\
\hline Observations & 1829 & 1829 & 1829 & 1829 & 1829 \\
\hline
\end{tabular}

Notes: Standard errors clustered at the community the mother was residing in the calendar year she turned 10 years old are in parentheses. ${ }^{* *}$ significant at $1 \%, * *$ significant at $5 \%, *$ significant at $10 \%$. Child's age is 
measured in months at the time the HAZ measure is collected. All specifications include mother's ethnicity and dummies for missing values of rainfall shock in the mother's $13^{\text {th }}$ year of life, but estimates are not reported. 
Table 7. OLS estimates of the impact of rainfall shocks during the mother's $13^{\text {th }}$ year of life on child quantitative achievement scores from age 5 to $15 \mathrm{y}$ in the India, Peru, and Vietnam pooled sample and by country

\begin{tabular}{|c|c|c|c|c|}
\hline & \multicolumn{4}{|c|}{ Pooled Sample (India, Peru, and Vietnam) } \\
\hline & Score $5 \mathrm{y}$ & Score 8 y & Score 12 y & Score $15 \mathrm{y}$ \\
\hline Rainfall shock & -0.0003 & -0.0010 & 0.0010 & -0.0003 \\
\hline mother's $13 \mathrm{y}$ & $(0.0008)$ & $(0.0007)$ & $(0.0008)$ & $(0.0007)$ \\
\hline \multirow[t]{2}{*}{ Male } & -0.016 & 0.044 & -0.004 & $0.077 * * *$ \\
\hline & $(0.028)$ & $(0.027)$ & $(0.027)$ & $(0.030)$ \\
\hline R-squared & 0.026 & 0.060 & 0.057 & 0.052 \\
\hline \multirow[t]{2}{*}{ Observations } & 4857 & 4857 & 4857 & 4857 \\
\hline & \multicolumn{4}{|c|}{ Ethiopia } \\
\hline $\begin{array}{l}\text { Rainfall shock } \\
\text { mother's } 13 \text { y }\end{array}$ & $\begin{array}{c}0.0018 \\
(0.0022)\end{array}$ & $\begin{array}{c}0.0004 \\
(0.0018)\end{array}$ & $\begin{array}{c}0.0004 \\
(0.0022)\end{array}$ & $\begin{array}{c}0.0003 \\
(0.0021)\end{array}$ \\
\hline \multirow[t]{2}{*}{ Male } & 0.003 & 0.035 & -0.006 & 0.030 \\
\hline & $(0.053)$ & $(0.051)$ & $(0.057)$ & $(0.050)$ \\
\hline R-squared & 0.073 & 0.179 & 0.112 & 0.161 \\
\hline \multirow[t]{2}{*}{ Observations } & 1307 & 1307 & 1307 & 1307 \\
\hline & \multicolumn{4}{|c|}{ India } \\
\hline Rainfall shock & -0.0004 & -0.0006 & 0.0029 & $0.0042 * * *$ \\
\hline mother's 13 y & $(0.0015)$ & $(0.0017)$ & $(0.0018)$ & $(0.0016)$ \\
\hline \multirow[t]{2}{*}{ Male } & -0.001 & -0.014 & -0.013 & $0.179 * * *$ \\
\hline & $(0.051)$ & $(0.048)$ & $(0.051)$ & $(0.048)$ \\
\hline R-squared & 0.039 & 0.077 & 0.069 & 0.084 \\
\hline \multirow[t]{2}{*}{ Observations } & 1546 & 1546 & 1546 & 1546 \\
\hline & \multicolumn{4}{|c|}{ Peru } \\
\hline Rainfall shock & 0.0005 & $-0.0025^{*}$ & -0.0001 & -0.0015 \\
\hline mother's 13 y & $(0.0019)$ & $(0.0015)$ & $(0.0012)$ & $(0.0017)$ \\
\hline \multirow[t]{2}{*}{ Male } & $-0.093^{*}$ & $0.118^{* *}$ & 0.055 & $0.175^{* * *}$ \\
\hline & $(0.052)$ & $(0.048)$ & $(0.043)$ & $(0.043)$ \\
\hline R-squared & 0.016 & 0.102 & 0.074 & 0.053 \\
\hline \multirow[t]{2}{*}{ Observations } & 1688 & 1688 & 1688 & 1688 \\
\hline & \multicolumn{4}{|c|}{ Vietnam } \\
\hline Rainfall shock & 0.0004 & 0.0001 & 0.0010 & -0.0009 \\
\hline mother's 13 y & (0.0009) & (0.0009) & $(0.0010)$ & (0.0009) \\
\hline \multirow[t]{2}{*}{ Male } & 0.025 & -0.013 & $-0.084 * *$ & $-0.142 * * *$ \\
\hline & $(0.043)$ & $(0.039)$ & $(0.042)$ & $(0.047)$ \\
\hline R-squared & 0.106 & 0.119 & 0.093 & 0.089 \\
\hline Observations & 1623 & 1623 & 1623 & 1623 \\
\hline
\end{tabular}

Notes: Standard errors clustered at the community the mother was residing in the calendar year she turned 10 years old are in parentheses. *** significant at 1\%, ** significant at 5\%, * significant at $10 \%$.

Dependent variables are age-normalised test scores. All specifications include controls for mother's ethnicity, the language of administration of the test, and whether the test was administered in the child's mother tongue, but estimates are not reported. 


\section{References}

Addo, O. Y., A.D. Stein, C. H. Fall, D.P. Gigante, A.M. Guntupalli, B.L. Horta, ... R. Martorell (2013) 'Maternal height and child growth patterns', The Journal of Pediatrics 163.2: 549-554.e1.

Akresh, R., S. Bhalotra, M. Leone, and U.O. Osili (2012) 'War and stature: growing up during the Nigerian civil war', American Economic Review: Papers and Proceedings 102.3: 273-277.

Akresh, R., S. Bhalotra, M. Leone, and U.O. Osili (2017) 'First and second generation impacts of the Biafran war', NBER working paper no. 23321.

Almond, D., and J. Currie (2011) 'Human capital development before age five', In O. Ashenfelter, D.E. Card, A. Hanushek and F.Welch (eds.) Handbook of Labor Economics. Vol. 4B, 1315-1486. Amsterdam: Elsevier B.V.

Angrist, J., and A. Krueger (1999) 'Empirical Strategies in Labor Economics', In O. Ashenfelter, D.E. Card, A. Hanushek and F.Welch (eds.) Handbook of Labor Economics. Vol. 3A, 1277-1366. Amsterdam: Elsevier B.V.

Angrist, J., and J-S. Pischke (2009) Mostly Harmless Econometrics: An Empiricist's Guide. Princeton, NJ: Princeton University Press.

Auffhammer, M., S.M. Hsiang, W. Schlenker, and A. Sobel (2013) 'Using weather data and climate model output in economic analyses of climate change', Review of Environmental Economics and Policy, 7.2: 181-198. 
Barnett, I., P. Ariana, S. Petrou, M.E. Penny, L.T. Duc, S. Galab, ... J. Boyden (2013) 'Cohort profile: the Young Lives study', International Journal of Epidemiology 42.3: 701-8.

Black, R.E., C.G. Victora, S.P. Walker, Z.A. Bhutta, P. Christian, M. de Onis, ... R. Uauy (2013) 'Maternal and child undernutrition and overweight in low-income and middle-income countries', The Lancet 382.9890: 427-451.

Cameron, A.C., J.G. Gelbach, and D.L. Miller (2008) 'Bootstrap-based improvements for inference wth clustered errors', Review of Economics and Statistics, 90: 414-27.

Cameron, A.C., and D.L. Miller (2015) 'A Practitioner's Guide to Cluster-Robust Inference', Journal of Human Resources, 50: 317-372.

Campisi, S.C., B. Carducci, O. Sober, and Z.A. Bhutta (2018) 'The intricate relationship between chronic undernutrition, impaired linear growth and delayed puberty: Is 'catch-up' growth possible during adolescence?', Unicer Office of Research-Innocenti working paper WP2018-12, July.

Case, A., and C. Paxson (2008) 'Stature and status: height, ability, and labor market outcomes', Journal of Political Economy 116.3: 499-532.

Crookston, B.T., W. Schott, S. Cueto, K.A. Dearden, P. Engle, A. Georgiadis, ... J.R. Behrman (2013) 'Postinfancy growth, schooling, and cognitive achievement: Young Lives', The American Journal of Clinical Nutrition 98.6: 1555-63. 
Cueto, S., and J. León (2012) 'Psychometric characteristics of cognitive development and achievement instruments in Round 3 of Young Lives', Young Lives Technical Note no. 25.

Cueto, S., J. León, G. Guerrero, and I. Muñoz (2009) 'Psychometric characteristics of cognitive development and achievement instruments in Round 2 of Young Lives', Young Lives Technical Note no. 15.

Cunha, F., and J.J. Heckman (2007) 'The technology of skill formation', American Economic Review 97.2: 31-47.

Currie, J., and T. Vogl (2013) 'Early-life health and adult circumstance in developing countries', Annual Review of Economics 5.1: 1-36.

Das, J.K., R.A. Salam, K.L. Thornburg, A.M. Prentice, S. Campisi, Z.S. Lassi, ...Z.A. Bhutta (2017) 'Nutrition in adolescents; physiology, metabolism, and nutritional needs', Annals of the New York Academy of Sciences 1393.2017: 21-33.

de Onis, M., A.W. Onyango, E. Borghi, A. Siyam, C. Nishida, and J. Siekmann (2007) 'Development of a WHO growth reference for school-aged children and adolescents', Bulletin of the World Health Organization, 85: 660-667.

Dell, M., B.F. Jones, and B. A. Olken (2014) 'What do we learn from the weather? The new climate-economy literature', Journal of Economic Literature, 52.3: 740-798.

Dewey, K.G., and K. Begum (2011) 'Long-term consequences of stunting in early life', Maternal \& Child Nutrition 7.s3: 5-18. 
Eckert, K.L., V.A. Loffredo, and K. O’Connor (2009) 'Adolescent physiology. In Behavioral Approaches to Chronic Disease in Adolescence: A Guide to Integrative Care. W.T. O’Donohue, Ed.: 29-45. New York, NY: Springer.

Fisher, R.A. (1935). The Design of Experiments, Edinburgh: Oliver and Boyd, Ltd, 1935.

Francesconi, M. (2008) 'Adult outcomes for children of teenage mothers', Scandinavian Journal of Economics 11.1: 93-117.

Furstenberg, F.F., J. Brooks-Gunn, and S.P. Morgan (1989) 'Teenaged pregnancy and childbearing', American Psychologist 44.2: 313-320.

Galasso, E., A. Wagstaff, S. Naudeau, and M. Shekar (2017) 'The economic costs of stunting and how to reduce them', Policy Research Note, World Bank.

Georgiadis, A. (2017) 'The sooner the better but it's never too late: the impact of nutrition at different periods of childhood', Young Lives Working Paper no. 159.

Georgiadis, A., and M.E. Penny (2017) 'Child undernutrition: opportunities beyond the first 1000 days', The Lancet Public Health, 2: e399.

Glewwe, P., H. Jacoby, and E. King (2001) 'Early childhood nutrition and academic achievement: a longitudinal analysis', Journal of Public Economics 81.3: 345-368. 
Glewwe, P., and E.A. Miguel (2008) 'The Impact of child health and nutrition on education in less developed countries', in P. Schultz and J. Strauss (eds.), Handbook of Development Economics, Vol. 4, 3561-3606. Amsterdam: Elsevier.

Grantham-McGregor, S., Y. Bun Cheung, S. Cueto, P. Glewwe, L. Richter, and B. Strupp (2007) 'Developmental potential in the first 5 years for children in developing countries', The Lancet 369: 60-70.

Heckman, J.J. (2007) 'The economics, technology, and neuroscience of human capability formation', Proceedings of the National Academy of Sciences 104.33: 13250-13255.

Maccini, S., and D. Yang (2009) 'Under the weather: health, schooling, and economic consequences of early-life rainfall', American Economic Review 99.3: 1006-1026.

Martorell, R., and A. Zongrone (2012) 'Intergenerational influences on child growth and undernutrition', Paediatric and Perinatal Epidemiology 26.s1: 302-314.

Maccini, S., and D. Yang. (2009) 'Under the weather: health, schooling, and economic consequences of early-life rainfall', American Economic Review, 99: 1006-1026.

Mendez, M.A., and L.S. Adair (1999) 'Severity and timing of stunting in the first two years of life affect performance on cognitive tests in late childhood', The Journal of Nutrition 129.8: $1555-1562$.

Pathania, V. (2007) 'The long run impact of drought at birth on height of women in rural India', 
unpublished manuscript.

Prendergast, A.J., and J.H. Humphrey (2014) 'The stunting syndrome in developing countries', Paediatrics and International Child Health 34.4: 250-265.

Prentice, A.M., K.A. Ward, G.R. Goldberg, L.M. Jarjou, S.E. Moore, A.J. Fulford, and A. Prentice (2013) 'Critical windows for nutritional interventions against stunting', The American Journal of Clinical Nutrition 97.5: 911-8.

Ramani, S., T. Frühauf, and A. Dutta (2017) 'On diarrhoea in adolescents and school toilets: insights from an Indian villate school study', Journal of Development Studies 53.11: 18991914.

Rutter, M.L. (1998) 'Developmental catch-up and deficit following adoption after severe global early privation', Journal of Child Psychology and Psychiatry 39.4: 465-476.

Schick, A., and R.H. Steckel (2015) 'Height, human Capital, and earnings: the contributions of cognitive and noncognitive ability', Journal of Human Capital 9.1: 94-115.

Skoufias, E., and K. Vinha, (2012) 'Climate variability and child height in rural Mexico', Economics and Human Biology 10.1: 54-73.

Steckel, R.H. (1987) 'Growth depression and recovery: the remarkable case of American slaves', Annals of Human Biology 14: 111-132. 
Strauss, J., and D. Thomas (1998) 'Health, nutrition and economic development', Journal of Economic Literature 36.2: 766-817.

Thiam, S., A.N. Diène, I. Sy, M.S. Winkler, C. Schindler, J.A. Ndione, O. Faye, et al. (2017) 'Association between childhood diarrhoeal incidence and climatic factors in urban and rural settings in the health district of Mbour, Senegal', International Journal of Environmental Research and Public Health 14.1049: 1-16.

Van den Berg, G.J., P. Lundborg, P. Nystedt, D.O. Rooth (2009) 'Critical periods during childhood and adolescence', Journal of the European Economic Association, 12: 1521-1557.

Veena, S.R, C.R. Gale, G.V. Krishnaveni, S.H. Kehoe, K. Shrinivasan, and C.H. Fall (2016) 'Association between maternal nutritional status in pregnancy and offspring cognitive function during childhood and adolescence: a systematic review', BMC Pregnancy Childbirth 16: 220244.

Willmott, C.J., and K. Matsuura (2012) 'Terrestrial precipitation, 1900-2010 gridded monthly time series (V 3.02)', Newark, Center for Climatic Research, Department of Geography, University of Delaware.

World Health Organisation (WHO) Multicentre Growth Reference Study Group (2007) 'WHO Child Growth Standards based on length/height, weight and age', Acta Paediatrica 95.S450): $76-85$.

World Health Organisation (WHO) (2012) Adolescent Pregnancy. Geneva: WHO. 
Young, A. (2019) 'Channeling Fisher: randomization tests and the statistical insignificance of seemingly significant experimental results', Quarterly Journal of Economics, 134: 557-598.

Young, A. (2020) 'Consistency without Inference: Instrumental Variables in Practice', Unpublished manuscript, London School of Economics. 


\section{Appendix}

Table A1. Descriptive statistics of mother's ethnicity and parental investments by country

\begin{tabular}{|c|c|c|c|c|}
\hline & Ethiopia & India & Peru & Vietnam \\
\hline Amhara & $\begin{array}{c}0.29 \\
(0.45)\end{array}$ & & & \\
\hline Gurage & $\begin{array}{c}0.08 \\
(0.27)\end{array}$ & & & \\
\hline Hadiya & $\begin{array}{c}0.04 \\
(0.21)\end{array}$ & & & \\
\hline Oromo & $\begin{array}{c}0.20 \\
(0.40)\end{array}$ & & & \\
\hline Sidama & $\begin{array}{c}0.06 \\
(0.23)\end{array}$ & & & \\
\hline Tigrian & $\begin{array}{c}0.22 \\
(0.42)\end{array}$ & & & \\
\hline Wolayta & $\begin{array}{c}0.06 \\
(0.24)\end{array}$ & & & \\
\hline Scheduled castes & & $\begin{array}{c}0.18 \\
(0.38)\end{array}$ & & \\
\hline Scheduled tribes & & $\begin{array}{c}0.13 \\
(0.34)\end{array}$ & & \\
\hline Other backward classes & & $\begin{array}{c}0.48 \\
(0.50)\end{array}$ & & \\
\hline Quechua & & & $\begin{array}{c}0.19 \\
(0.39)\end{array}$ & \\
\hline White & & & $\begin{array}{c}0.03 \\
(0.18)\end{array}$ & \\
\hline Mixed ethnicity & & & $\begin{array}{c}0.73 \\
(0.44)\end{array}$ & \\
\hline Kin'h & & & & $\begin{array}{c}0.86 \\
(0.35)\end{array}$ \\
\hline Hmong & & & & $\begin{array}{c}0.05 \\
(0.23)\end{array}$ \\
\hline Other ethnicities & $\begin{array}{c}0.04 \\
(0.20)\end{array}$ & $\begin{array}{c}0.21 \\
(0.41)\end{array}$ & $\begin{array}{c}0.05 \\
(0.22)\end{array}$ & $\begin{array}{c}0.02 \\
(0.28)\end{array}$ \\
\hline Expenditure on child's health in the last 12 months $8 \mathrm{y}$ & $\begin{array}{l}134.31 \\
(83.51)\end{array}$ & $\begin{array}{c}647.73 \\
(386.87)\end{array}$ & $\begin{array}{l}116.82 \\
(68.00)\end{array}$ & $\begin{array}{c}447.98 \\
(317.55)\end{array}$ \\
\hline Child's dietary diversity score in the last 24 hours $8 y$ & $\begin{array}{c}5.10 \\
(1.81)\end{array}$ & $\begin{array}{c}6.44 \\
(1.63)\end{array}$ & $\begin{array}{c}8.99 \\
(1.83)\end{array}$ & $\begin{array}{l}7.74 \\
(2.30)\end{array}$ \\
\hline Number of meals consumed by the child in the last 24 hours $8 \mathrm{y}$ & $\begin{array}{c}3.93 \\
(0.70)\end{array}$ & $\begin{array}{c}4.86 \\
(1.10)\end{array}$ & $\begin{array}{c}4.87 \\
(0.88)\end{array}$ & $\begin{array}{c}4.33 \\
(1.07)\end{array}$ \\
\hline Expenditure on child's health in the last 12 months $12 \mathrm{y}$ & $\begin{array}{c}86.99 \\
(1014.75)\end{array}$ & $\begin{array}{c}1539.09 \\
(4227.57)\end{array}$ & $\begin{array}{c}47.33 \\
(230.34)\end{array}$ & $\begin{array}{c}545.62 \\
(2762.25)\end{array}$ \\
\hline Child's dietary diversity score in the last 24 hours 12 y & $\begin{array}{c}5.39 \\
(1.60)\end{array}$ & $\begin{array}{c}6.54 \\
(1.48)\end{array}$ & $\begin{array}{c}9.04 \\
(1.71)\end{array}$ & $\begin{array}{c}7.28 \\
(2.42)\end{array}$ \\
\hline Number of meals consumed by the child in the last 24 hours $12 \mathrm{y}$ & $\begin{array}{c}3.91 \\
(0.76)\end{array}$ & $\begin{array}{c}4.68 \\
(0.99)\end{array}$ & $\begin{array}{c}4.52 \\
(0.90)\end{array}$ & $\begin{array}{c}4.02 \\
(1.09)\end{array}$ \\
\hline Expenditure on child's health in the last 12 months $15 \mathrm{y}$ & $\begin{array}{c}82.50 \\
(405.53)\end{array}$ & $\begin{array}{c}2965.13 \\
(14629.87)\end{array}$ & $\begin{array}{c}49.88 \\
(170.43)\end{array}$ & $\begin{array}{c}615.81 \\
(2411.76)\end{array}$ \\
\hline Child's dietary diversity score in the last 24 hours $15 \mathrm{y}$ & $\begin{array}{c}5.68 \\
(1.69)\end{array}$ & $\begin{array}{c}6.95 \\
(1.75)\end{array}$ & $\begin{array}{l}8.80 \\
(2.04)\end{array}$ & $\begin{array}{l}7.61 \\
(2.33)\end{array}$ \\
\hline Number of meals consumed by the child in the last 24 hours $15 \mathrm{y}$ & $\begin{array}{c}3.81 \\
(0.73)\end{array}$ & $\begin{array}{c}4.42 \\
(0.98)\end{array}$ & $\begin{array}{c}4.43 \\
(1.02)\end{array}$ & $\begin{array}{c}3.84 \\
(0.99)\end{array}$ \\
\hline Number of observations & 1781 & 1869 & 1794 & 1879 \\
\hline
\end{tabular}

Notes: Statistics are means with standard deviations in parentheses. The sample is restricted to children with non-missing or no extreme values in height-for-age Z-scores (greater than 6 in absolute value) or non-missing test scores in all rounds. Expenditure on child's health in the last 12 months is measured in country currency and 
includes expenditure on medical consultation, treatment, and medication. The dietary diversity score is the number of different food groups consumed by the child in the last 24 hours, out of 17 groups in total. 
Table A2. Descriptive statistics of language of administration of quantitative achievement tests

\begin{tabular}{|c|c|c|c|c|}
\hline & Ethiopia & India & Peru & Vietnam \\
\hline \multicolumn{5}{|l|}{ Child's mother tongue } \\
\hline \multirow[t]{2}{*}{ Amharic } & 0.44 & & & \\
\hline & $(0.50)$ & & & \\
\hline \multirow[t]{2}{*}{ Oromiya } & 0.25 & & & \\
\hline & $(0.43)$ & & & \\
\hline \multirow[t]{2}{*}{ Tigrigna } & 0.17 & & & \\
\hline & $(0.38)$ & & & \\
\hline \multirow[t]{2}{*}{ Other Ethiopian languages } & 0.14 & & & \\
\hline & $(0.34)$ & & & \\
\hline \multirow[t]{2}{*}{ Telugu } & & 0.93 & & \\
\hline & & $(0.26)$ & & \\
\hline \multirow[t]{2}{*}{ Kannada } & & 0.04 & & \\
\hline & & $(0.19)$ & & \\
\hline \multirow[t]{2}{*}{ Other Indian languages } & & 0.03 & & \\
\hline & & $(0.19)$ & & \\
\hline \multirow[t]{2}{*}{ Spanish } & & & 0.90 & \\
\hline & & & $(0.30)$ & \\
\hline \multirow[t]{2}{*}{ Quechua } & & & 0.10 & \\
\hline & & & $(0.30)$ & \\
\hline \multirow[t]{2}{*}{ Other Peruvian languages } & & & 0.00 & \\
\hline & & & $(0.02)$ & \\
\hline \multirow[t]{2}{*}{ Vietnamese } & & & & 0.81 \\
\hline & & & & $(0.39)$ \\
\hline \multirow[t]{2}{*}{ H'mong } & & & & 0.04 \\
\hline & & & & $(0.20)$ \\
\hline \multirow[t]{2}{*}{ Other Vietnamese languages } & & & & 0.15 \\
\hline & & & & $(0.36)$ \\
\hline \multicolumn{5}{|l|}{ Language of administration of cognitive tests } \\
\hline \multirow[t]{2}{*}{ CDA test at $5 \mathrm{y}$ administered in mother tongue } & 0.99 & 0.95 & 0.97 & 0.97 \\
\hline & $(0.10)$ & $(0.22)$ & $(0.16)$ & $(0.16)$ \\
\hline \multirow[t]{2}{*}{ Maths test at $8 \mathrm{y}$ administered in mother tongue } & 0.61 & 0.74 & 0.92 & 0.82 \\
\hline & $(0.49)$ & $(0.44)$ & $(0.27)$ & $(0.39)$ \\
\hline \multirow[t]{2}{*}{ Maths test at $12 \mathrm{y}$ administered in mother tongue } & 0.52 & 0.93 & 0.90 & 0.81 \\
\hline & $(0.50)$ & $(0.26)$ & $(0.30)$ & $(0.39)$ \\
\hline \multirow[t]{2}{*}{ Maths test at $15 \mathrm{y}$ administered in mother tongue } & 0.51 & 0.92 & 0.90 & 0.81 \\
\hline & $(0.50)$ & $(0.27)$ & $(0.30)$ & $(0.39)$ \\
\hline Number of observations & 1781 & 1869 & 1794 & 1879 \\
\hline
\end{tabular}

Notes: Statistics are means with standard deviations in parentheses. 
Table A3. OLS estimates of the impact of rainfall shocks at different periods of mother's adolescence on maternal adult height

\begin{tabular}{lccccc}
\hline \hline & Ethiopia & India & Peru & Vietnam & All countries \\
\hline Rainfall shock 10 y & 0.0003 & -0.0069 & $-0.0247^{* *}$ & $-0.0078^{*}$ & $-0.0061^{*}$ \\
& $(0.0187)$ & $(0.0128)$ & $(0.0106)$ & $(0.0043)$ & $(0.0035)$ \\
Rainfall shock 11 y & -0.0261 & -0.0086 & -0.0124 & $0.0123^{* *}$ & 0.0010 \\
& $(0.0173)$ & $(0.0105)$ & $(0.0103)$ & $(0.0050)$ & $(0.0038)$ \\
Rainfall shock 12 y & -0.0048 & -0.0124 & -0.0148 & -0.0003 & -0.0055 \\
& $(0.0162)$ & $(0.0112)$ & $(0.0112)$ & $(0.0048)$ & $(0.0037)$ \\
Rainfall shock 13 y & $0.0278^{*}$ & -0.0190 & $-0.0306 * * *$ & $-0.0099 * *$ & $-0.0127 * *$ \\
& $(0.0159)$ & $(0.0128)$ & $(0.0096)$ & $(0.0048)$ & $(0.0036)$ \\
Rainfall shock 14 y & $0.0418^{* * *}$ & $-0.0289 * * *$ & 0.0020 & -0.0057 & $-0.0081^{* *}$ \\
& $(0.0161)$ & $(0.0111)$ & $(0.0086)$ & $(0.0049)$ & $(0.0035)$ \\
Rainfall shock 15 y & $0.0522^{* * *}$ & -0.0048 & -0.0009 & -0.0003 & -0.0003 \\
& $(0.0159)$ & $(0.0122)$ & $(0.0085)$ & $(0.0046)$ & $(0.0035)$ \\
Rainfall shock 16 y & $0.0454^{* *}$ & -0.0007 & $0.0164 *$ & $-0.0091 * *$ & -0.0029 \\
& $(0.0179)$ & $(0.0107)$ & $(0.0094)$ & $(0.0043)$ & $(0.0033)$ \\
Rainfall shock 17 y & $0.0483^{* * *}$ & 0.0134 & 0.0102 & -0.0069 & -0.0030 \\
Rainfall shock 18 y & $(0.0164)$ & $(0.0115)$ & $(0.0087)$ & $(0.0045)$ & $(0.0034)$ \\
& $0.0378^{* *}$ & -0.0002 & 0.0009 & 0.0049 & -0.0007 \\
Rainfall shock 19 y & $(0.0164)$ & $(0.0115)$ & $(0.0091)$ & $(0.0042)$ & $(0.0033)$ \\
R-squared & $0.0316^{* *}$ & 0.0021 & 0.0092 & -0.0053 & -0.0019 \\
Kleibergen-Paap F- & $(0.0151)$ & $(0.0128)$ & $(0.0101)$ & $(0.0042)$ & $(0.0036)$ \\
statistic & 0.031 & 0.038 & 0.040 & 0.076 & 0.245 \\
Observations & 2.90 & 1.01 & 2.03 & 2.43 & 2.38
\end{tabular}

Notes: Robust standard errors are in parentheses. *** significant at $1 \%$, ** significant at 5\%, * significant at $10 \%$. Controls included in all specifications for child age in 2002, child gender, and mother's ethnicity, but coefficients are not reported. 
Table A4. OLS estimates of the impact of rainfall shocks in the mother's $13^{\text {th }}$ year of life on child nutritional status from age 1 to $15 \mathrm{y}$ in the India, Peru, and Vietnam pooled sample and by country

\begin{tabular}{|c|c|c|c|c|c|}
\hline & \multicolumn{5}{|c|}{ Pooled Sample (India, Peru, and Vietnam) } \\
\hline & HAZ 1 y & HAZ 5 y & HAZ 8 y & HAZ 12 y & HAZ 15 y \\
\hline Rainfall shock & $-0.0026 * * *$ & $-0.0025 * * *$ & $-0.0022 * * *$ & $-0.0025 * * *$ & $-0.0021 * * *$ \\
\hline mother's $13 \mathrm{y}$ & $(0.0008)$ & $(0.0006)$ & $(0.0007)$ & $(0.0007)$ & $(0.0006)$ \\
\hline \multirow[t]{2}{*}{ Male } & $-0.178 * * *$ & -0.029 & $-0.046 *$ & 0.033 & $0.109 * * *$ \\
\hline & $(0.034)$ & $(0.027)$ & $(0.027)$ & $(0.028)$ & $(0.024)$ \\
\hline \multirow[t]{2}{*}{ Child's age } & $-0.093 * * *$ & $0.029 * * *$ & $-0.008 * *$ & $-0.014 * * *$ & $-0.007 * *$ \\
\hline & $(0.005)$ & $(0.003)$ & $(0.004)$ & $(0.004)$ & $(0.003)$ \\
\hline R-squared & 0.108 & 0.093 & 0.089 & 0.105 & 0.095 \\
\hline \multirow[t]{2}{*}{ Observations } & 5383 & 5383 & 5383 & 5383 & 5383 \\
\hline & \multicolumn{5}{|c|}{ Ethiopia } \\
\hline \multirow{2}{*}{$\begin{array}{l}\text { Rainfall shock } \\
\text { mother's } 13 \text { y }\end{array}$} & 0.0005 & 0.0015 & 0.0017 & 0.0006 & $0.0040^{*}$ \\
\hline & $(0.0040)$ & $(0.0024)$ & $(0.0023)$ & $(0.0020)$ & $(0.0023)$ \\
\hline \multirow[t]{2}{*}{ Male } & $-0.379 * * *$ & $-0.089 *$ & $-0.133 * *$ & 0.035 & $-0.810 * * *$ \\
\hline & $(0.087)$ & $(0.054)$ & $(0.055)$ & $(0.049)$ & $(0.051)$ \\
\hline \multirow[t]{2}{*}{ Child's age } & $-0.120 * * *$ & $-0.016 * *$ & 0.002 & -0.003 & $0.019 * * *$ \\
\hline & $(0.012)$ & $(0.007)$ & $(0.007)$ & $(0.006)$ & $(0.007)$ \\
\hline R-squared & 0.104 & 0.024 & 0.019 & 0.021 & 0.162 \\
\hline \multirow[t]{2}{*}{ Observations } & 1622 & 1622 & 1622 & 1622 & 1622 \\
\hline & \multicolumn{5}{|c|}{ India } \\
\hline $\begin{array}{l}\text { Rainfall shock } \\
\text { mother's } 13 \text { y }\end{array}$ & $\begin{array}{l}-0.0043 * \\
(0.0022)\end{array}$ & $\begin{array}{c}0.0011 \\
(0.0014)\end{array}$ & $\begin{array}{c}0.0013 \\
(0.0016)\end{array}$ & $\begin{array}{c}0.0015 \\
(0.0016)\end{array}$ & $\begin{array}{c}-0.0002 \\
(0.0015)\end{array}$ \\
\hline \multirow[t]{2}{*}{ Male } & $-0.181 * * *$ & $-0.114 * *$ & -0.070 & 0.016 & 0.012 \\
\hline & $(0.067)$ & $(0.045)$ & $(0.048)$ & $(0.048)$ & $(0.044)$ \\
\hline \multirow[t]{2}{*}{ Child's age } & $-0.085 * * *$ & 0.006 & -0.004 & -0.006 & -0.006 \\
\hline & $(0.009)$ & $(0.006)$ & $(0.006)$ & $(0.006)$ & $(0.006)$ \\
\hline R-squared & 0.069 & 0.029 & 0.047 & 0.039 & 0.040 \\
\hline \multirow[t]{2}{*}{ Observations } & 1803 & 1803 & 1803 & 1803 & 1803 \\
\hline & \multicolumn{5}{|c|}{ Peru } \\
\hline \multirow{2}{*}{$\begin{array}{l}\text { Rainfall shock } \\
\text { mother's } 13 \text { y }\end{array}$} & -0.0024 & -0.0028 & $-0.0046 * * *$ & $-0.0039 * *$ & -0.0020 \\
\hline & $(0.0020)$ & $(0.0017)$ & $(0.0016)$ & $(0.0017)$ & $(0.0012)$ \\
\hline \multirow[t]{2}{*}{ Male } & $-0.208 * * *$ & 0.001 & -0.025 & 0.041 & $0.239 * * *$ \\
\hline & $(0.058)$ & $(0.049)$ & $(0.048)$ & $(0.051)$ & $(0.041)$ \\
\hline \multirow[t]{2}{*}{ Child's age } & $-0.085 * * *$ & $0.059 * * *$ & -0.005 & $-0.018 * *$ & $-0.011 *$ \\
\hline & $(0.008)$ & $(0.005)$ & $(0.007)$ & $(0.007)$ & $(0.006)$ \\
\hline R-squared & 0.108 & 0.129 & 0.064 & 0.054 & 0.056 \\
\hline \multirow[t]{2}{*}{ Observations } & 1751 & 1751 & 1751 & 1751 & 1751 \\
\hline & \multicolumn{5}{|c|}{ Vietnam } \\
\hline \multirow{2}{*}{$\begin{array}{l}\text { Rainfall shock } \\
\text { mother's } 13 \text { y }\end{array}$} & -0.0013 & $-0.0026^{* * *}$ & $-0.0020 * *$ & $-0.0026 * * *$ & $-0.0025 * * *$ \\
\hline & $(0.0009)$ & $(0.0008)$ & $(0.0008)$ & $(0.0008)$ & $(0.0007)$ \\
\hline \multirow[t]{2}{*}{ Male } & $-0.166 * * *$ & 0.010 & -0.051 & 0.039 & $0.074 *$ \\
\hline & $(0.052)$ & $(0.044)$ & $(0.046)$ & (0.049) & $(0.039)$ \\
\hline \multirow[t]{2}{*}{ Child's age } & $-0.111 * * *$ & -0.004 & $-0.015 * *$ & $-0.014 * *$ & -0.008 \\
\hline & $(0.009)$ & $(0.006)$ & $(0.007)$ & $(0.007)$ & $(0.006)$ \\
\hline R-squared & 0.201 & 0.147 & 0.132 & 0.161 & 0.105 \\
\hline Observations & 1829 & 1829 & 1829 & 1829 & 1829 \\
\hline
\end{tabular}

Notes: Robust standard errors are in parentheses. $* * *$ significant at $1 \%, * *$ significant at $5 \%, *$ significant at $10 \%$. Child's age is measured in months at the time the HAZ measure is collected. All specifications include 
mother's ethnicity and dummies for missing values of rainfall shock in the mother's $13^{\text {th }}$ year of life, but estimates are not reported. 
Table A5. OLS estimates of the impact of rainfall shocks during the mother's $13^{\text {th }}$ year of life on child quantitative achievement scores from age 5 to $15 \mathrm{y}$ in the India, Peru, and Vietnam pooled sample and by country

\begin{tabular}{|c|c|c|c|c|}
\hline & \multicolumn{4}{|c|}{ Pooled Sample (India, Peru, and Vietnam) } \\
\hline & Score $5 \mathrm{y}$ & Score 8 y & Score 12 y & Score $15 \mathrm{y}$ \\
\hline Rainfall shock & -0.0003 & -0.0010 & 0.0010 & -0.0003 \\
\hline mother's $13 \mathrm{y}$ & $(0.0007)$ & $(0.0007)$ & $(0.0007)$ & $(0.0007)$ \\
\hline \multirow[t]{2}{*}{ Male } & -0.016 & 0.044 & -0.004 & $0.077 * * *$ \\
\hline & $(0.028)$ & $(0.027)$ & $(0.027)$ & $(0.027)$ \\
\hline R-squared & 0.026 & 0.060 & 0.057 & 0.052 \\
\hline \multirow[t]{2}{*}{ Observations } & 4857 & 4857 & 4857 & 4857 \\
\hline & \multicolumn{4}{|c|}{ Ethiopia } \\
\hline $\begin{array}{l}\text { Rainfall shock } \\
\text { mother's } 13 \text { y }\end{array}$ & $\begin{array}{c}0.0018 \\
(0.0025)\end{array}$ & $\begin{array}{c}0.0004 \\
(0.0022)\end{array}$ & $\begin{array}{c}0.0004 \\
(0.0023)\end{array}$ & $\begin{array}{c}0.0003 \\
(0.0021)\end{array}$ \\
\hline \multirow[t]{2}{*}{ Male } & 0.003 & 0.035 & -0.006 & 0.030 \\
\hline & $(0.053)$ & $(0.050)$ & $(0.051)$ & $(0.049)$ \\
\hline R-squared & 0.073 & 0.179 & 0.112 & 0.161 \\
\hline \multirow[t]{2}{*}{ Observations } & 1307 & 1307 & 1307 & 1307 \\
\hline & \multicolumn{4}{|c|}{ India } \\
\hline \multirow{2}{*}{$\begin{array}{l}\text { Rainfall shock } \\
\text { mother's } 13 \text { y }\end{array}$} & -0.0004 & -0.0006 & $0.0029 *$ & $0.0042 * *$ \\
\hline & $(0.0017)$ & $(0.0016)$ & $(0.0015)$ & $(0.0016)$ \\
\hline \multirow[t]{2}{*}{ Male } & -0.001 & -0.014 & -0.013 & $0.179 * * *$ \\
\hline & $(0.049)$ & $(0.048)$ & $(0.048)$ & $(0.048)$ \\
\hline R-squared & 0.039 & 0.077 & 0.069 & 0.084 \\
\hline \multirow[t]{2}{*}{ Observations } & 1546 & 1546 & 1546 & 1546 \\
\hline & \multicolumn{4}{|c|}{ Peru } \\
\hline \multirow{2}{*}{$\begin{array}{l}\text { Rainfall shock } \\
\text { mother's } 13 \text { y }\end{array}$} & 0.0005 & $-0.0025^{*}$ & -0.0001 & -0.0015 \\
\hline & $(0.0017)$ & $(0.0015)$ & $(0.0017)$ & $(0.0015)$ \\
\hline \multirow[t]{2}{*}{ Male } & $-0.093 * *$ & $0.118 * * *$ & 0.055 & $0.175^{* * *} *$ \\
\hline & $(0.047)$ & $(0.046)$ & $(0.046)$ & $(0.046)$ \\
\hline R-squared & 0.016 & 0.102 & 0.074 & 0.053 \\
\hline \multirow[t]{2}{*}{ Observations } & 1688 & 1688 & 1688 & 1688 \\
\hline & \multicolumn{4}{|c|}{ Vietnam } \\
\hline \multirow{2}{*}{$\begin{array}{l}\text { Rainfall shock } \\
\text { mother's } 13 \text { y }\end{array}$} & 0.0004 & 0.0001 & 0.0010 & -0.0009 \\
\hline & $(0.0008)$ & $(0.0008)$ & $(0.0008)$ & $(0.0008)$ \\
\hline \multirow[t]{2}{*}{ Male } & 0.025 & -0.013 & $-0.084 *$ & $-0.142 * * *$ \\
\hline & $(0.045)$ & $(0.045)$ & $(0.047)$ & $(0.047)$ \\
\hline R-squared & 0.106 & 0.119 & 0.093 & 0.089 \\
\hline Observations & 1623 & 1623 & 1623 & 1623 \\
\hline
\end{tabular}

Notes: Robust standard errors are in parentheses. $* * *$ significant at $1 \%, * *$ significant at $5 \%, *$ significant at $10 \%$.

Dependent variables are age-normalised test scores. All specifications include controls for mother's ethnicity, the language of administration of the test, and whether the test was administered in the child's mother tongue, but estimates are not reported. 
Table A6. OLS estimates of the impact of rainfall shocks between the $7^{\text {th }}$ and $10^{\text {th }}$ year of the child's life, realised after mother's height was observed, on maternal height across countries and in the pooled countries sample

\begin{tabular}{|c|c|c|c|c|c|}
\hline & \multicolumn{5}{|c|}{ Maternal height } \\
\hline & Ethiopia & India & Peru & Vietnam & $\begin{array}{l}\text { Pooled } \\
\text { sample }\end{array}$ \\
\hline Rainfall shock & -0.001 & -0.001 & 0.004 & 0.001 & 0.001 \\
\hline child's 7 y & $(0.003)$ & $(0.002)$ & $(0.003)$ & $(0.001)$ & $(0.001)$ \\
\hline Rainfall shock & -0.004 & 0.002 & $0.009 * * *$ & -0.001 & -0.001 \\
\hline child's 8 y & $(0.004)$ & $(0.001)$ & $(0.003)$ & $(0.001)$ & $(0.001)$ \\
\hline Rainfall shock & -0.005 & -0.001 & -0.004 & -0.001 & 0.001 \\
\hline child's 9 y & $(0.005)$ & $(0.001)$ & $(0.004)$ & $(0.001)$ & $(0.001)$ \\
\hline Rainfall shock & 0.004 & 0.001 & -0.003 & 0.001 & -0.001 \\
\hline child's 10 y & $(0.005)$ & $(0.001)$ & $(0.003)$ & $(0.001)$ & $(0.001)$ \\
\hline R-squared & 0.017 & 0.034 & 0.048 & 0.065 & 0.243 \\
\hline Observations & 1622 & 1803 & 1751 & 1829 & 7005 \\
\hline
\end{tabular}

Notes: Standard errors clustered at the community the child was residing in round 2, when mothers' height measures were obtained, in parentheses. *** significant at $1 \%$, ** significant at $5 \%,{ }^{*}$ significant at $10 \%$. Child's age is measured in months at the time the HAZ measure is collected. All specifications include child's age and gender, mother's ethnicity, and dummies for missing values of rainfall shock in the $7^{\text {th }}, 8^{\text {th }}, 9^{\text {th }}$, and $10^{\text {th }}$ year of child's life, but estimates are not reported. 
Table A7i. TSLS estimates of the impact of maternal adolescent nutritional status on child nutritional status at age 1 and $5 \mathrm{y}$ including potential mediators in the India, Peru, and Vietnam pooled sample

\begin{tabular}{|c|c|c|c|c|c|c|}
\hline & \multicolumn{2}{|c|}{ HAZ 1 y } & \multicolumn{4}{|c|}{ HAZ 5 y } \\
\hline & (1) & (2) & (1) & (2) & (3) & (4) \\
\hline Mother's & $0.188 * *$ & $0.201 * * *$ & $0.181 * * *$ & $0.193 * * *$ & $0.139 * *$ & $0.131 * *$ \\
\hline adult height & $(0.085)$ & $(0.078)$ & $(0.063)$ & $(0.059)$ & $(0.058)$ & $(0.055)$ \\
\hline Male & $-0.137 * * *$ & $-0.142 * * *$ & 0.012 & 0.006 & $0.047 *$ & $0.047^{*}$ \\
\hline Child's age & $\begin{array}{l}(0.040) \\
-0.089 * * * \\
(0.008)\end{array}$ & $\begin{array}{l}(0.040) \\
-0.088 * * * \\
(0.008)\end{array}$ & $\begin{array}{l}(0.031) \\
0.021 * * * \\
(0.007)\end{array}$ & $\begin{array}{l}(0.031) \\
0.012 * * \\
(0.006)\end{array}$ & $\begin{array}{l}(0.028) \\
0.031 * * * \\
(0.006)\end{array}$ & $\begin{array}{l}(0.027) \\
0.032 * * * \\
(0.006)\end{array}$ \\
\hline $\begin{array}{l}\text { Mother's } \\
\text { education }\end{array}$ & & $\begin{array}{c}0.008 \\
(0.012)\end{array}$ & & $\begin{array}{c}0.008 \\
(0.008)\end{array}$ & $\begin{array}{c}0.005 \\
(0.006)\end{array}$ & $\begin{array}{c}0.004 \\
(0.006)\end{array}$ \\
\hline $\begin{array}{l}\text { Father's } \\
\text { education }\end{array}$ & & $\begin{array}{c}0.011 \\
(0.008)\end{array}$ & & $\begin{array}{c}0.008 \\
(0.006)\end{array}$ & $\begin{array}{c}0.005 \\
(0.004)\end{array}$ & $\begin{array}{c}0.004 \\
(0.004)\end{array}$ \\
\hline Wealth index & & 0.274 & & $0.407 * *$ & $0.248 * *$ & $0.225^{*}$ \\
\hline $1 \mathrm{y}$ & & $(0.223)$ & & $(0.168)$ & $(0.120)$ & $(0.120)$ \\
\hline $\begin{array}{l}\text { Urban } \\
\text { location } 1 \mathrm{y}\end{array}$ & & $\begin{array}{l}0.207 * * \\
(0.097)\end{array}$ & & $\begin{array}{l}0.296^{* * * *} \\
(0.081)\end{array}$ & $\begin{array}{l}0.240 * * * \\
(0.075)\end{array}$ & $\begin{array}{l}0.223 * * * \\
(0.072)\end{array}$ \\
\hline HAZ 1 y & & & & & $\begin{array}{l}0.290 * * * \\
(0.060)\end{array}$ & $\begin{array}{l}0.295^{* * *} \\
(0.057)\end{array}$ \\
\hline $\begin{array}{l}\text { Expenditure } \\
\text { on child's } \\
\text { health } 5 \mathrm{y}\end{array}$ & & & & & & $\begin{array}{c}0.001 \\
(0.001)\end{array}$ \\
\hline $\begin{array}{l}\text { Dietary } \\
\text { diversity } 5 \text { y }\end{array}$ & & & & & & $\begin{array}{l}0.027 * * * \\
(0.010)\end{array}$ \\
\hline $\begin{array}{l}\text { Number of } \\
\text { meals } 5 \mathrm{y}\end{array}$ & & & & & & $\begin{array}{l}-0.004 \\
(0.018)\end{array}$ \\
\hline $\begin{array}{l}\text { Kleibergen- } \\
\text { Paap F- } \\
\text { statistic }\end{array}$ & 14.44 & 14.43 & 14.30 & 14.33 & 8.93 & 9.37 \\
\hline Observations & 5383 & 5383 & 5383 & 5383 & 5383 & 5383 \\
\hline
\end{tabular}

Notes: Standard errors clustered at the sentinel site are in parentheses. $* * *$ significant at $1 \%$, $* *$ significant at $5 \%, *$ significant at $10 \%$. The sample is restricted to children with non-missing or no extreme values in height-for-age Z-scores (greater than 6 in absolute value) in all rounds in India, Peru, and Vietnam. Child's age is measured in months at the time the HAZ score measure is collected. TSLS estimation is using rainfall in the calendar year the mother completed her $13^{\text {th }}$ year of age as an instrument for mother's adult height. All specifications include mother's ethnicity, but estimates are not reported. Dummies for missing values in control variables, such as mother's education, father's education, wealth index, expenditure on child's health, dietary diversity, and the number of meals, are included in specifications containing these variables, but estimates are not reported. 
Table A7ii. TSLS estimates of the impact of maternal adolescent nutritional status on child nutritional status at age $8 \mathrm{y}$ including potential mediators in the India, Peru, and Vietnam pooled sample

\begin{tabular}{|c|c|c|c|c|c|c|}
\hline & \multicolumn{6}{|c|}{ HAZ 8 y } \\
\hline & (1) & (2) & (3) & (4) & $(5)$ & $(6)$ \\
\hline Mother's & $0.164 * * *$ & $0.181 * * *$ & $0.138 * *$ & $0.133 * *$ & 0.052 & 0.058 \\
\hline adult height & $(0.062)$ & $(0.056)$ & $(0.056)$ & $(0.055)$ & $(0.040)$ & $(0.039)$ \\
\hline Male & -0.011 & -0.018 & 0.018 & 0.019 & -0.010 & -0.008 \\
\hline & $(0.029)$ & $(0.028)$ & $(0.023)$ & $(0.023)$ & $(0.018)$ & $(0.018)$ \\
\hline Child's age in & -0.003 & -0.002 & $0.018 * * *$ & $0.018 * * *$ & 0.001 & 0.001 \\
\hline Round 3 & $(0.005)$ & $(0.005)$ & $(0.005)$ & $(0.004)$ & $(0.003)$ & $(0.003)$ \\
\hline $\begin{array}{l}\text { Mother's } \\
\text { education }\end{array}$ & & $\begin{array}{c}0.013 \\
(0.009)\end{array}$ & $\begin{array}{c}0.010 \\
(0.007)\end{array}$ & $\begin{array}{c}0.009 \\
(0.007)\end{array}$ & $\begin{array}{c}0.006 \\
(0.004)\end{array}$ & $\begin{array}{c}0.006 \\
(0.004)\end{array}$ \\
\hline Father's & & 0.007 & 0.004 & 0.004 & 0.001 & 0.001 \\
\hline education & & $(0.006)$ & $(0.004)$ & $(0.004)$ & $(0.003)$ & $(0.003)$ \\
\hline Wealth index & & $0.395^{* *}$ & $0.303 * *$ & $0.271 * *$ & 0.075 & 0.085 \\
\hline $1 \mathrm{y}$ & & $(0.165)$ & $(0.131)$ & $(0.130)$ & $(0.075)$ & $(0.075)$ \\
\hline $\begin{array}{l}\text { Urban } \\
\text { location } 1 \mathrm{y}\end{array}$ & & $\begin{array}{l}0.298 * * * \\
(0.087)\end{array}$ & $\begin{array}{l}0.256 * * * \\
(0.082)\end{array}$ & $\begin{array}{l}0.247 * * * \\
(0.081)\end{array}$ & $\begin{array}{c}0.106^{*} \\
(0.058)\end{array}$ & $\begin{array}{c}0.107^{*} \\
(0.060)\end{array}$ \\
\hline HAZ 1 y & & & $\begin{array}{l}0.250 * * * \\
(0.059)\end{array}$ & $\begin{array}{l}0.253^{* * * *} \\
(0.058)\end{array}$ & $\begin{array}{l}0.075^{* * * *} \\
(0.017)\end{array}$ & $\begin{array}{l}0.074 * * * \\
(0.017)\end{array}$ \\
\hline $\begin{array}{l}\text { Expenditure } \\
\text { on child's } \\
\text { health } 5 \mathrm{y}\end{array}$ & & & & $\begin{array}{c}0.001 \\
(0.001)\end{array}$ & $\begin{array}{c}0.001 \\
(0.001)\end{array}$ & $\begin{array}{c}0.001 \\
(0.001)\end{array}$ \\
\hline Dietary & & & & $0.027 * * *$ & 0.011 & 0.010 \\
\hline diversity 5 y & & & & $(0.010)$ & $(0.007)$ & $(0.007)$ \\
\hline Number of & & & & -0.001 & 0.002 & 0.004 \\
\hline meals 5 y & & & & $(0.015)$ & $(0.009)$ & $(0.009)$ \\
\hline HAZ 5 y & & & & & $\begin{array}{l}0.605 * * * \\
(0.074)\end{array}$ & $\begin{array}{l}0.595 * * * \\
(0.071)\end{array}$ \\
\hline $\begin{array}{l}\text { Expenditure } \\
\text { on child's } \\
\text { health } 8 \mathrm{y}\end{array}$ & & & & & & $\begin{array}{l}-0.001 \\
(0.001)\end{array}$ \\
\hline $\begin{array}{l}\text { Dietary } \\
\text { diversity } 8 \text { y }\end{array}$ & & & & & & $\begin{array}{c}0.003 \\
(0.005)\end{array}$ \\
\hline $\begin{array}{l}\text { Number of } \\
\text { meals } 8 \mathrm{y}\end{array}$ & & & & & & $\begin{array}{l}-0.018 \\
(0.013)\end{array}$ \\
\hline $\begin{array}{l}\text { Kleibergen- } \\
\text { Paap F- } \\
\text { statistic }\end{array}$ & 13.98 & 14 & 9.06 & 9.49 & 5.86 & 6.28 \\
\hline Observations & 5383 & 5383 & 5383 & 5383 & 5383 & 5383 \\
\hline
\end{tabular}

Notes: Standard errors clustered at the sentinel site are in parentheses. $* * *$ significant at $1 \%, * *$ significant at $5 \%, *$ significant at $10 \%$. The sample is restricted to children with non-missing or no extreme values in height-for-age Z-scores (greater than 6 in absolute value) in all rounds in India, Peru, and Vietnam. TSLS estimation is using rainfall in the calendar year the mother completed her $13^{\text {th }}$ year of age as an instrument for mother's adult height. All specifications include mother's ethnicity, but estimates are not reported. Dummies for missing values in control variables, such as mother's education, father's education, wealth index, expenditure on child's health, dietary diversity, and the number of meals, are included in specifications containing these variables, but estimates are not reported. 
Table A7iii. TSLS estimates of the impact of maternal adolescent nutritional status on child nutritional status at age $12 \mathrm{y}$ including potential mediators in the India, Peru, and Vietnam pooled sample

\begin{tabular}{|c|c|c|c|c|c|c|c|c|}
\hline & \multicolumn{8}{|c|}{ HAZ 12 y } \\
\hline & (1) & (2) & (3) & (4) & (5) & (6) & (7) & (8) \\
\hline Mother's & $0.182 * *$ & $0.197 * * *$ & $0.162 * *$ & $0.152 * *$ & 0.078 & 0.075 & 0.045 & 0.046 \\
\hline adult height & $(0.072)$ & $(0.065)$ & $(0.071)$ & $(0.068)$ & $(0.062)$ & $(0.058)$ & $(0.053)$ & $(0.054)$ \\
\hline Male & $0.072 * *$ & $0.064 * *$ & $0.095 * * *$ & $0.096 * * *$ & $0.069 * * *$ & $0.068 * * *$ & $0.072 * * *$ & $0.071 * * *$ \\
\hline & $(0.033)$ & $(0.032)$ & $(0.028)$ & $(0.028)$ & $(0.025)$ & $(0.025)$ & $(0.021)$ & $(0.021)$ \\
\hline Child's age in & -0.006 & -0.005 & $0.011 * *$ & $0.012 * *$ & -0.004 & -0.004 & $-0.005^{* *}$ & $-0.005^{* *}$ \\
\hline Round 4 & $(0.006)$ & $(0.006)$ & $(0.005)$ & $(0.005)$ & $(0.003)$ & $(0.003)$ & $(0.002)$ & $(0.002)$ \\
\hline Mother's & & 0.006 & 0.003 & 0.003 & 0.001 & 0.001 & -0.002 & -0.003 \\
\hline education & & $(0.010)$ & $(0.008)$ & $(0.008)$ & $(0.005)$ & $(0.005)$ & $(0.004)$ & $(0.004)$ \\
\hline Father's & & $0.012 *$ & $0.010^{*}$ & $0.009 *$ & $0.007 *$ & 0.006 & $0.006^{*}$ & $0.006^{*}$ \\
\hline education & & $(0.007)$ & $(0.006)$ & $(0.005)$ & $(0.004)$ & $(0.004)$ & $(0.003)$ & $(0.003)$ \\
\hline Wealth index & & $0.406 * *$ & $0.335^{* *}$ & $0.315 * *$ & 0.133 & $0.143^{*}$ & 0.102 & 0.109 \\
\hline $1 \mathrm{y}$ & & $(0.186)$ & $(0.148)$ & $(0.148)$ & $(0.088)$ & $(0.086)$ & $(0.070)$ & $(0.070)$ \\
\hline Urban & & $0.294 * * *$ & $0.258 * * *$ & $0.231 * * *$ & 0.106 & 0.092 & 0.039 & 0.042 \\
\hline location $1 \mathrm{y}$ & & $(0.090)$ & $(0.086)$ & $(0.084)$ & $(0.073)$ & $(0.072)$ & $(0.058)$ & $(0.059)$ \\
\hline HAZ 1 y & & & $0.206 * * *$ & $0.214 * * *$ & $0.054 * *$ & $0.055^{* *}$ & 0.018 & 0.018 \\
\hline & & & $(0.075)$ & $(0.072)$ & $(0.023)$ & $(0.022)$ & $(0.016)$ & $(0.016)$ \\
\hline Expenditure & & & & -0.001 & -0.001 & -0.001 & -0.001 & -0.001 \\
\hline on child's & & & & $(0.001)$ & $(0.001)$ & $(0.001)$ & $(0.001)$ & $(0.001)$ \\
\hline health $5 \mathrm{y}$ & & & & & & & & \\
\hline Dietary & & & & $0.035^{* * *}$ & $0.020 * *$ & $0.016^{*}$ & $0.011^{*}$ & 0.011 \\
\hline diversity $5 \mathrm{y}$ & & & & $(0.011)$ & $(0.009)$ & $(0.009)$ & $(0.007)$ & $(0.007)$ \\
\hline Number of & & & & 0.009 & 0.012 & 0.009 & 0.007 & 0.007 \\
\hline meals 5 y & & & & $(0.017)$ & $(0.011)$ & $(0.011)$ & $(0.010)$ & $(0.010)$ \\
\hline HAZ 5 y & & & & & $0.546 * * *$ & $0.550 * * *$ & $0.259 * * *$ & $0.257 * * *$ \\
\hline & & & & & $(0.109)$ & $(0.104)$ & $(0.065)$ & $(0.066)$ \\
\hline Expenditure & & & & & & 0.001 & 0.001 & 0.001 \\
\hline on child's & & & & & & $(0.001)$ & $(0.001)$ & $(0.001)$ \\
\hline health $8 \mathrm{y}$ & & & & & & & & \\
\hline Dietary & & & & & & 0.007 & 0.005 & 0.004 \\
\hline diversity $8 \mathrm{y}$ & & & & & & $(0.007)$ & $(0.006)$ & $(0.006)$ \\
\hline Number of & & & & & & 0.008 & 0.017 & 0.018 \\
\hline meals 8 y & & & & & & $(0.015)$ & $(0.012)$ & $(0.012)$ \\
\hline HAZ 8 y & & & & & & & $0.492 * * *$ & $0.491 * * *$ \\
\hline & & & & & & & $(0.071)$ & $(0.071)$ \\
\hline Expenditure & & & & & & & & 0.001 \\
\hline on child's & & & & & & & & $(0.001)$ \\
\hline health $12 \mathrm{y}$ & & & & & & & & \\
\hline Dietary & & & & & & & & 0.009 \\
\hline diversity 12 y & & & & & & & & $(0.006)$ \\
\hline Number of & & & & & & & & -0.019 \\
\hline meals 12 y & & & & & & & & $(0.014)$ \\
\hline Kleibergen- & & & & & & & & \\
\hline $\begin{array}{l}\text { Paap F- } \\
\text { statistic }\end{array}$ & 13.92 & 14.01 & 9.02 & 9.45 & 5.82 & 6.25 & 5.69 & 5.45 \\
\hline Observations & 5383 & 5383 & 5383 & 5383 & 5383 & 5383 & 5383 & 5383 \\
\hline
\end{tabular}

Notes: Standard errors clustered at the sentinel site are in parentheses. $* * *$ significant at $1 \%$, ** significant at $5 \%$, * significant at $10 \%$. The sample is restricted to children with non-missing or no extreme values in height-for-age Z-scores (greater than 6 in absolute value) in all rounds in India, Peru, and Vietnam. TSLS estimation is using rainfall in the calendar year the mother completed her $13^{\text {th }}$ year of age as an instrument for mother's adult height. All specifications include mother's ethnicity, but estimates are not reported. Dummies for missing values in control variables, such as mother's 
education, father's education, wealth index, expenditure on child's health, dietary diversity, and the number of meals, are included in specifications containing these variables, but estimates are not reported. 
Table A7iv. TSLS estimates of the impact of maternal adolescent nutritional status on child nutritional status at age $15 \mathrm{y}$ including potential mediators in the India, Peru, and Vietnam pooled sample

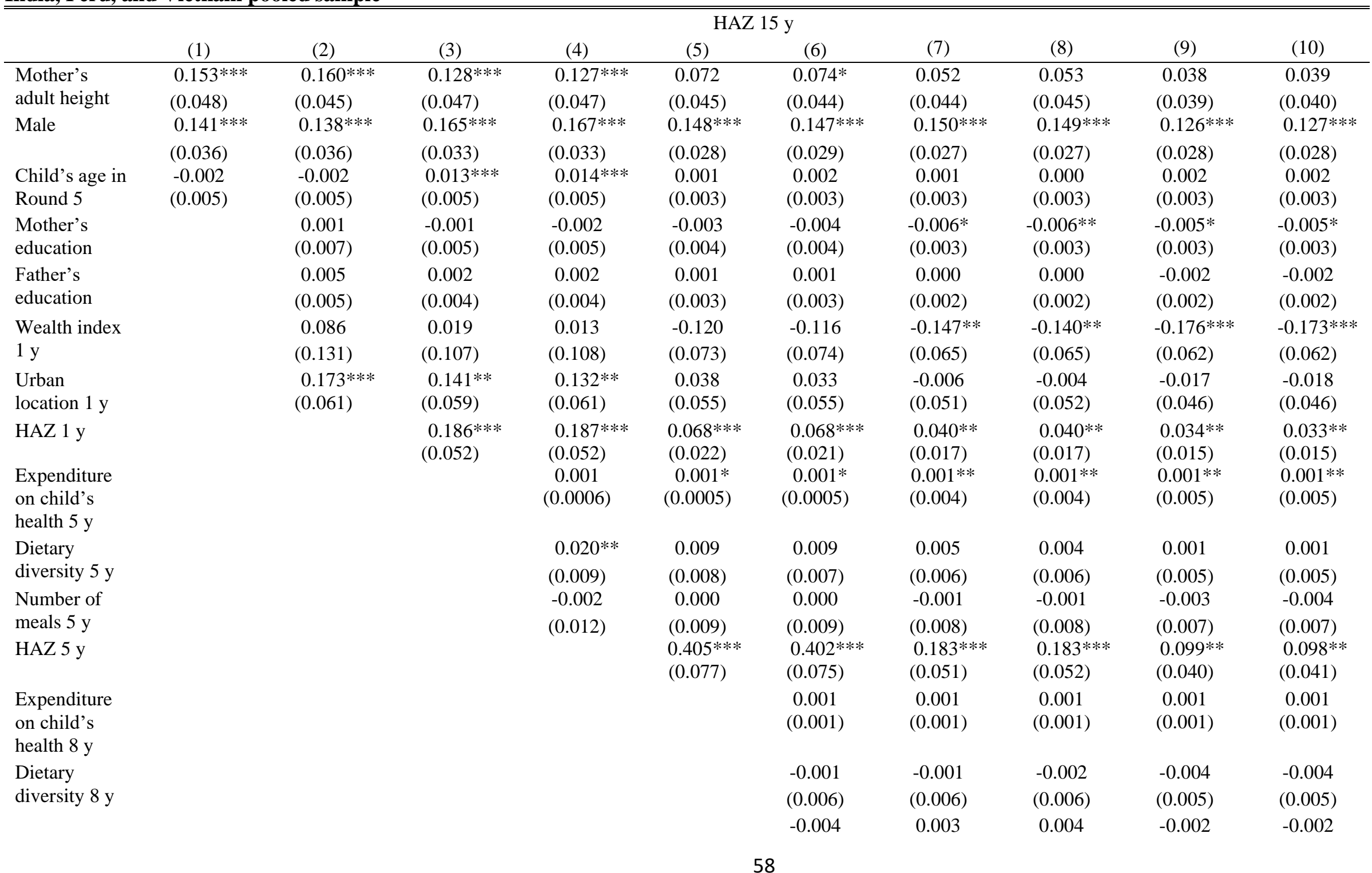




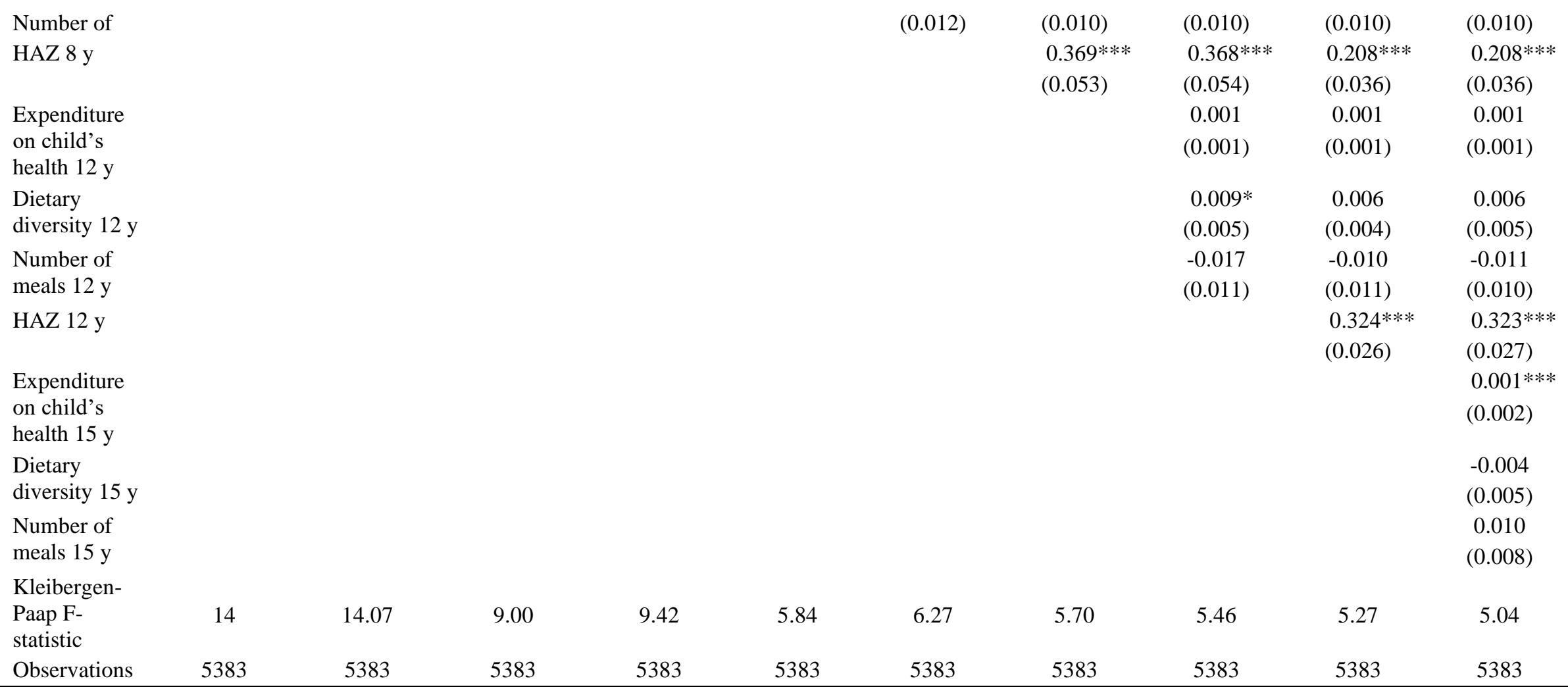

Notes: Standard errors clustered at the sentinel site are in parentheses. *** significant at $1 \%, * *$ significant at $5 \%, *$ significant at $10 \%$. The sample is restricted to children with non-missing or no extreme values in height-for-age Z-scores (greater than 6 in absolute value) in all rounds in India, Peru, and Vietnam. TSLS estimation is using rainfall in the calendar year the mother completed her $13^{\text {th }}$ year of age as an instrument for mother's adult height. All specifications include mother's ethnicity, but estimates are not reported. Dummies for missing values in control variables, such as mother's education, father's education, wealth index, expenditure on child's health, dietary diversity, and the number of meals, are included in specifications containing these variables, but estimates are not reported. 
Table A8. OLS and TSLS estimates of the impact of maternal adolescent nutrition on child nutritional status from age 1 to $15 \mathrm{y}$ in the India, Peru, and Vietnam pooled sample of children with non-missing $\mathrm{HAZ}$ and achievement test scores in all rounds

\begin{tabular}{|c|c|c|c|c|c|}
\hline & \multicolumn{5}{|c|}{ OLS } \\
\hline & HAZ 1 y & HAZ 5 y & HAZ 8 y & HAZ 12 y & HAZ 15 y \\
\hline Mother's adult & $0.058 * * *$ & $0.059 * * *$ & $0.057 * * *$ & $0.056 * * *$ & $0.057 * * *$ \\
\hline height & $(0.004)$ & $(0.003)$ & $(0.003)$ & $(0.004)$ & $(0.003)$ \\
\hline \multirow[t]{2}{*}{ Male } & $-0.160 * * *$ & -0.002 & -0.018 & $0.050 *$ & $0.145 * * *$ \\
\hline & $(0.037)$ & $(0.028)$ & $(0.028)$ & $(0.029)$ & $(0.030)$ \\
\hline \multirow[t]{2}{*}{ Child's age } & $-0.092 * * *$ & $0.027 * * *$ & -0.007 & $-0.011 * *$ & -0.006 \\
\hline & $(0.007)$ & $(0.007)$ & $(0.005)$ & $(0.005)$ & $(0.005)$ \\
\hline R-squared & 0.165 & 0.190 & 0.177 & 0.175 & 0.212 \\
\hline \multirow[t]{2}{*}{ Observations } & 4857 & 4857 & 4857 & 4857 & 4857 \\
\hline & \multicolumn{5}{|c|}{ TSLS } \\
\hline $\begin{array}{l}\text { Mother's adult } \\
\text { height }\end{array}$ & $\begin{array}{l}0.229 * * \\
(0.093)\end{array}$ & $\begin{array}{l}0.208 * * * \\
(0.065)\end{array}$ & $\begin{array}{l}0.179 * * * \\
(0.063)\end{array}$ & $\begin{array}{l}0.203 * * * \\
(0.071)\end{array}$ & $\begin{array}{l}0.155 * * * \\
(0.044)\end{array}$ \\
\hline \multirow[t]{2}{*}{ Male } & $-0.133 * * *$ & 0.023 & 0.001 & $0.073 * *$ & $0.160 * * *$ \\
\hline & $(0.043)$ & $(0.033)$ & $(0.030)$ & $(0.033)$ & $(0.034)$ \\
\hline \multirow[t]{2}{*}{ Child's age } & $-0.088 * * *$ & $0.020 * * *$ & -0.003 & -0.006 & -0.003 \\
\hline & $(0.009)$ & $(0.007)$ & $(0.006)$ & $(0.006)$ & $(0.005)$ \\
\hline $\begin{array}{l}\text { Kleibergen-Paap } \\
\text { F-statistic }\end{array}$ & 12.30 & 12.10 & 11.80 & 11.89 & 11.88 \\
\hline Observations & 4857 & 4857 & 4857 & 4857 & 4857 \\
\hline
\end{tabular}

Notes: Standard errors clustered at the sentinel site are in parentheses. $* * *$ significant at $1 \%$, ** significant at $5 \%$, $*$ significant at $10 \%$. The sample is restricted to children with non-missing or no extreme values in height-for-age Z-scores (greater than 6 in absolute value) and non-missing quantitative achievement test scores in all rounds in India, Peru, and Vietnam. Child's age is measured in months at the time the HAZ score measure is collected. TSLS estimation is using rainfall in the calendar year the mother completed her $13^{\text {th }}$ year of age as an instrument for mother's adult height. All specifications control for mother's ethnicity, but estimates are not reported. 
Table A9. OLS estimates of the impact of rainfall shocks in the mother's $13^{\text {th }}$ year of life on child nutritional status from age 1 to $15 \mathrm{y}$ in the India, Peru, and Vietnam pooled sample and by country based on children with non-missing HAZ and achievement test scores in all rounds

\begin{tabular}{|c|c|c|c|c|c|}
\hline & \multicolumn{5}{|c|}{ Pooled Sample (India, Peru, and Vietnam) } \\
\hline & HAZ 1 y & HAZ 5 y & HAZ 8 y & HAZ 12 y & HAZ 15 y \\
\hline Rainfall shock & $-0.0030 * * *$ & $-0.0027 * * *$ & $-0.0023 * * *$ & $-0.0026 * * *$ & $-0.0020 * * *$ \\
\hline mother's 13 y & $(0.0009)$ & $(0.0007)$ & $(0.0006)$ & $(0.0007)$ & $(0.0006)$ \\
\hline \multirow[t]{2}{*}{ Male } & $-0.170 * * *$ & -0.012 & -0.027 & 0.041 & $0.136 * * *$ \\
\hline & $(0.035)$ & $(0.029)$ & $(0.029)$ & $(0.029)$ & $(0.027)$ \\
\hline \multirow[t]{2}{*}{ Child's age } & $-0.093 * * *$ & $0.030 * * *$ & $-0.009 * *$ & $-0.013 * * *$ & $-0.007 *$ \\
\hline & $(0.006)$ & $(0.004)$ & $(0.004)$ & $(0.005)$ & $(0.004)$ \\
\hline R-squared & 0.107 & 0.086 & 0.082 & 0.092 & 0.090 \\
\hline \multirow[t]{2}{*}{ Observations } & 4857 & 4857 & 4857 & 4857 & 4857 \\
\hline & \multicolumn{5}{|c|}{ Ethiopia } \\
\hline \multirow{2}{*}{$\begin{array}{l}\text { Rainfall shock } \\
\text { mother's } 13 \text { y }\end{array}$} & -0.0034 & 0.0015 & 0.0019 & 0.0010 & 0.0037 \\
\hline & $(0.0046)$ & $(0.0031)$ & $(0.0025)$ & $(0.0026)$ & $(0.0025)$ \\
\hline \multirow[t]{2}{*}{ Male } & $-0.347 * * *$ & $-0.119 * *$ & $-0.117 * *$ & 0.035 & $-0.758 * * *$ \\
\hline & (0.109) & $(0.055)$ & $(0.052)$ & $(0.059)$ & $(0.059)$ \\
\hline \multirow[t]{2}{*}{ Child's age } & $-0.124 * * *$ & $-0.018 * *$ & -0.002 & -0.005 & $0.017 * *$ \\
\hline & $(0.017)$ & $(0.009)$ & $(0.008)$ & $(0.006)$ & $(0.007)$ \\
\hline R-squared & 0.108 & 0.023 & 0.016 & 0.038 & 0.159 \\
\hline \multirow[t]{2}{*}{ Observations } & 1307 & 1307 & 1307 & 1307 & 1307 \\
\hline & \multicolumn{5}{|c|}{ India } \\
\hline $\begin{array}{l}\text { Rainfall shock } \\
\text { mother's } 13 \text { y }\end{array}$ & $\begin{array}{l}-0.0050^{* *} \\
(0.0024)\end{array}$ & $\begin{array}{c}0.0010 \\
(0.0016)\end{array}$ & $\begin{array}{c}0.0012 \\
(0.0017)\end{array}$ & $\begin{array}{c}0.0012 \\
(0.0017)\end{array}$ & $\begin{array}{l}-0.0004 \\
(0.0016)\end{array}$ \\
\hline \multirow[t]{2}{*}{ Male } & $-0.148 * *$ & $-0.086^{*}$ & -0.028 & 0.063 & $0.078 *$ \\
\hline & $(0.069)$ & $(0.050)$ & $(0.055)$ & $(0.050)$ & $(0.045)$ \\
\hline \multirow[t]{2}{*}{ Child's age } & $-0.086 * * *$ & 0.007 & -0.004 & -0.008 & -0.003 \\
\hline & $(0.011)$ & $(0.007)$ & $(0.008)$ & $(0.008)$ & $(0.007)$ \\
\hline R-squared & 0.078 & 0.031 & 0.051 & 0.044 & 0.048 \\
\hline \multirow[t]{2}{*}{ Observations } & 1546 & 1546 & 1546 & 1546 & 1546 \\
\hline & \multicolumn{5}{|c|}{ Peru } \\
\hline \multirow{2}{*}{$\begin{array}{l}\text { Rainfall shock } \\
\text { mother's } 13 \mathrm{y}\end{array}$} & -0.0027 & $-0.0031^{*}$ & $-0.0049 * * *$ & $-0.0042 * *$ & $-0.0024 * *$ \\
\hline & $(0.0021)$ & $(0.0017)$ & $(0.0015)$ & $(0.0017)$ & $(0.0011)$ \\
\hline \multirow[t]{2}{*}{ Male } & $-0.220 * * *$ & 0.005 & -0.027 & 0.033 & $0.235^{* * *}$ \\
\hline & $(0.060)$ & $(0.050)$ & $(0.048)$ & $(0.048)$ & $(0.047)$ \\
\hline \multirow[t]{2}{*}{ Child's age } & $-0.085 * * *$ & $0.059 * * *$ & -0.005 & $-0.015^{*}$ & -0.010 \\
\hline & $(0.008)$ & $(0.007)$ & $(0.007)$ & $(0.008)$ & $(0.007)$ \\
\hline R-squared & 0.112 & 0.130 & 0.066 & 0.055 & 0.058 \\
\hline \multirow[t]{2}{*}{ Observations } & 1688 & 1688 & 1688 & 1688 & 1688 \\
\hline & & & Vietnam & & \\
\hline \multirow{2}{*}{$\begin{array}{l}\text { Rainfall shock } \\
\text { mother's } 13 \text { y }\end{array}$} & $-0.0016 *$ & $-0.0028 * * *$ & $-0.0019 * * *$ & $-0.0025 * * *$ & $-0.0021 * * *$ \\
\hline & $(0.0009)$ & $(0.0008)$ & $(0.0007)$ & $(0.0009)$ & $(0.0007)$ \\
\hline \multirow[t]{2}{*}{ Male } & $-0.161 * * *$ & 0.023 & -0.033 & 0.024 & $0.081^{*}$ \\
\hline & $(0.055)$ & $(0.047)$ & $(0.048)$ & $(0.052)$ & $(0.043)$ \\
\hline \multirow[t]{2}{*}{ Child's age } & $-0.110 * * *$ & -0.004 & $-0.017 * *$ & $-0.012 *$ & -0.007 \\
\hline & $(0.011)$ & $(0.007)$ & $(0.007)$ & $(0.007)$ & $(0.006)$ \\
\hline
\end{tabular}




$\begin{array}{lccccc}\text { R-squared } & 0.189 & 0.118 & 0.102 & 0.124 & 0.081 \\ \text { Observations } & 1623 & 1623 & 1623 & 1623 & 1623\end{array}$

Notes: Standard errors clustered at the community the mother was residing in the calendar year she turned 10 years old are in parentheses. ${ }^{* * *}$ significant at $1 \%$, ** significant at $5 \%$, * significant at $10 \%$. Child's age is measured in months at the time the HAZ measure is collected. All specifications include mother's ethnicity and dummies for missing values of rainfall shock in the mother's $13^{\text {th }}$ year of life, but estimates are not reported. 
Table A10i. OLS estimates of the impact of rainfall shocks in the mother's $13^{\text {th }}$ year of life on child nutritional status at age 1 and $5 y$ including potential mediators in the India, Peru, and Vietnam pooled sample

\begin{tabular}{|c|c|c|c|c|c|c|}
\hline & \multicolumn{2}{|c|}{ HAZ 1 y } & \multicolumn{4}{|c|}{ HAZ 5 y } \\
\hline & (1) & (2) & (1) & (2) & (3) & (4) \\
\hline Rainfall shock & $-0.0026 * * *$ & $-0.0029 * * *$ & $-0.0025 * * *$ & $-0.0028 * * *$ & $-0.0016 * * *$ & $-0.0015^{* * *}$ \\
\hline mother's $13 \mathrm{y}$ & $(0.0008)$ & $(0.0008)$ & $(0.0007)$ & $(0.0006)$ & $(0.0005)$ & $(0.0005)$ \\
\hline Male & $-0.178 * * *$ & $-0.188 * * *$ & -0.029 & -0.039 & $0.042 *$ & $0.042 *$ \\
\hline Child's age & $\begin{array}{l}(0.033) \\
-0.093 * * * \\
(0.006)\end{array}$ & $\begin{array}{l}(0.033) \\
-0.093 * * * \\
(0.006)\end{array}$ & $\begin{array}{l}(0.028) \\
0.029^{* * * *} \\
(0.004)\end{array}$ & $\begin{array}{l}(0.027) \\
0.014 * * * \\
(0.004)\end{array}$ & $\begin{array}{l}(0.024) \\
0.042 * * * \\
(0.003)\end{array}$ & $\begin{array}{l}(0.024) \\
0.042 * * * \\
(0.003)\end{array}$ \\
\hline $\begin{array}{l}\text { Mother's } \\
\text { education }\end{array}$ & & $\begin{array}{l}0.030 * * * \\
(0.006)\end{array}$ & & $\begin{array}{l}0.029 * * * \\
(0.005)\end{array}$ & $\begin{array}{l}0.015 * * * \\
(0.004)\end{array}$ & $\begin{array}{l}0.014 * * * \\
(0.004)\end{array}$ \\
\hline $\begin{array}{l}\text { Father's } \\
\text { education }\end{array}$ & & $\begin{array}{l}0.019 * * * \\
(0.005)\end{array}$ & & $\begin{array}{l}0.016 * * * \\
(0.004)\end{array}$ & $\begin{array}{l}0.008^{* *} \\
(0.004)\end{array}$ & $\begin{array}{l}0.007 * \\
(0.004)\end{array}$ \\
\hline Wealth index & & $0.747 * * *$ & & 0.856 *** & $0.426^{* * *}$ & $0.388 * * *$ \\
\hline $1 \mathrm{y}$ & & (0.134) & & (0.105) & $(0.080)$ & $(0.081)$ \\
\hline $\begin{array}{l}\text { Urban } \\
\text { location } 1 \mathrm{y}\end{array}$ & & $\begin{array}{c}0.095 \\
(0.062)\end{array}$ & & $\begin{array}{l}0.190 * * * \\
(0.049)\end{array}$ & $\begin{array}{l}0.149 \text { *** } \\
(0.037)\end{array}$ & $\begin{array}{l}0.142 * * * \\
(0.037)\end{array}$ \\
\hline HAZ 1 y & & & & & $\begin{array}{l}0.438 \text { *** } \\
(0.014)\end{array}$ & $\begin{array}{l}0.435 * * * \\
(0.014)\end{array}$ \\
\hline $\begin{array}{l}\text { Expenditure } \\
\text { on child's } \\
\text { health } 5 \mathrm{y}\end{array}$ & & & & & & $\begin{array}{l}0.001 * * \\
(0.005)\end{array}$ \\
\hline $\begin{array}{l}\text { Dietary } \\
\text { diversity } 5 \text { y }\end{array}$ & & & & & & $\begin{array}{l}0.028 * * * \\
(0.007)\end{array}$ \\
\hline $\begin{array}{l}\text { Number of } \\
\text { meals } 5 y\end{array}$ & & & & & & $\begin{array}{l}-0.014 \\
(0.011)\end{array}$ \\
\hline R-squared & 0.108 & 0.165 & 0.093 & 0.205 & 0.477 & 0.479 \\
\hline Observations & 5383 & 5383 & 5383 & 5383 & 5383 & 5383 \\
\hline
\end{tabular}

Notes: Standard errors clustered at the community the mother was residing in the calendar year she turned 10 years old are in parentheses. $* * *$ significant at $1 \%, * *$ significant at $5 \%, *$ significant at $10 \%$. The sample is restricted to children with non-missing or no extreme values in height-for-age Z-scores (greater than 6 in absolute value) in all rounds in India, Peru, and Vietnam. Child's age is measured in months at the time the HAZ score measure is collected. All specifications include mother's ethnicity, but estimates are not reported. Dummies for missing values in control variables, such as mother's education, father's education, wealth index, expenditure on child's health, dietary diversity, and the number of meals, are included in specifications containing these variables, but estimates are not reported. 
Table A10ii. OLS estimates of the impact of rainfall shocks in the mother's $13^{\text {th }}$ year of life on child nutritional status at age $8 \mathrm{y}$ including potential mediators in the India, Peru, and Vietnam pooled sample

\begin{tabular}{|c|c|c|c|c|c|c|}
\hline & \multicolumn{6}{|c|}{ HAZ 8 y } \\
\hline & $(1)$ & $(2)$ & (3) & (4) & $(5)$ & (6) \\
\hline $\begin{array}{l}\text { Rainfall shock } \\
\text { mother's } 13 \text { y }\end{array}$ & $\begin{array}{l}-0.0022 * * * \\
(0.0006)\end{array}$ & $\begin{array}{c}-0.0026 * * * \\
(0.0006)\end{array}$ & $\begin{array}{c}-0.0016 * * * \\
(0.0005)\end{array}$ & $\begin{array}{c}-0.0016 * * * \\
(0.0005)\end{array}$ & $\begin{array}{l}-0.0005 \\
(0.0004)\end{array}$ & $\begin{array}{l}-0.0006 \\
(0.0004)\end{array}$ \\
\hline Male & -0.046 & $-0.059 * *$ & 0.014 & 0.014 & -0.016 & -0.016 \\
\hline $\begin{array}{l}\text { Child's age in } \\
\text { Round } 3\end{array}$ & $\begin{array}{l}(0.028) \\
-0.008 * \\
(0.004)\end{array}$ & $\begin{array}{c}(0.026) \\
-0.009 * * \\
(0.004)\end{array}$ & $\begin{array}{l}(0.023) \\
0.025^{* * *} \\
(0.004)\end{array}$ & $\begin{array}{l}(0.024) \\
0.025^{* * *} \\
(0.003)\end{array}$ & $\begin{array}{c}(0.016) \\
0.001 \\
(0.003)\end{array}$ & $\begin{array}{c}(0.016) \\
0.001 \\
(0.003)\end{array}$ \\
\hline $\begin{array}{l}\text { Mother's } \\
\text { education }\end{array}$ & & $\begin{array}{l}0.032 * * * \\
(0.004)\end{array}$ & $\begin{array}{l}0.020 * * * \\
(0.004)\end{array}$ & $\begin{array}{l}0.018 * * * \\
(0.004)\end{array}$ & $\begin{array}{l}0.008 * * * \\
(0.003)\end{array}$ & $\begin{array}{l}0.009 * * * \\
(0.003)\end{array}$ \\
\hline $\begin{array}{l}\text { Father's } \\
\text { education }\end{array}$ & & $\begin{array}{l}0.014 * * * \\
(0.004)\end{array}$ & $\begin{array}{c}0.007 * \\
(0.004)\end{array}$ & $\begin{array}{c}0.006^{*} \\
(0.004)\end{array}$ & $\begin{array}{c}0.002 \\
(0.003)\end{array}$ & $\begin{array}{c}0.002 \\
(0.003)\end{array}$ \\
\hline $\begin{array}{l}\text { Wealth index } \\
1 \mathrm{y}\end{array}$ & & $\begin{array}{l}0.826 * * * \\
(0.088)\end{array}$ & $\begin{array}{l}0.517 * * * \\
(0.076)\end{array}$ & $\begin{array}{l}0.474 * * * \\
(0.077)\end{array}$ & $\begin{array}{c}0.108 * \\
(0.060)\end{array}$ & $\begin{array}{l}0.121 * * \\
(0.060)\end{array}$ \\
\hline $\begin{array}{l}\text { Urban } \\
\text { location } 1 \mathrm{y}\end{array}$ & & $\begin{array}{l}0.196 * * * \\
(0.038)\end{array}$ & $\begin{array}{l}0.169 * * * \\
(0.033)\end{array}$ & $\begin{array}{l}0.167 * * * \\
(0.033)\end{array}$ & $\begin{array}{l}0.062 * * \\
(0.025)\end{array}$ & $\begin{array}{l}0.057 * * \\
(0.025)\end{array}$ \\
\hline HAZ 1 y & & & $\begin{array}{l}0.395^{* * * *} \\
(0.011)\end{array}$ & $\begin{array}{l}0.393 * * * \\
(0.011)\end{array}$ & $\begin{array}{l}0.092 * * * \\
(0.011)\end{array}$ & $\begin{array}{l}0.092 * * * \\
(0.011)\end{array}$ \\
\hline $\begin{array}{l}\text { Expenditure } \\
\text { on child's } \\
\text { health } 5 \mathrm{y}\end{array}$ & & & & $\begin{array}{c}0.001 * \\
(0.0006)\end{array}$ & $\begin{array}{c}0.001 \\
(0.001)\end{array}$ & $\begin{array}{c}0.001 \\
(0.001)\end{array}$ \\
\hline $\begin{array}{l}\text { Dietary } \\
\text { diversity } 5 \mathrm{y}\end{array}$ & & & & $\begin{array}{l}0.029 * * * \\
(0.007)\end{array}$ & $\begin{array}{c}0.008 \\
(0.006)\end{array}$ & $\begin{array}{c}0.009 \\
(0.006)\end{array}$ \\
\hline $\begin{array}{l}\text { Number of } \\
\text { meals } 5 \text { y }\end{array}$ & & & & $\begin{array}{l}-0.011 \\
(0.011)\end{array}$ & $\begin{array}{l}-0.001 \\
(0.009)\end{array}$ & $\begin{array}{c}0.002 \\
(0.009)\end{array}$ \\
\hline HAZ 5 y & & & & & $\begin{array}{l}0.693 * * * \\
(0.020)\end{array}$ & $\begin{array}{l}0.693 * * * \\
(0.020)\end{array}$ \\
\hline $\begin{array}{l}\text { Expenditure } \\
\text { on child's } \\
\text { health } 8 \mathrm{y}\end{array}$ & & & & & & $\begin{array}{c}0.001 \\
(0.001)\end{array}$ \\
\hline $\begin{array}{l}\text { Dietary } \\
\text { diversity } 8 \text { y }\end{array}$ & & & & & & $\begin{array}{c}0.002 \\
(0.005)\end{array}$ \\
\hline $\begin{array}{l}\text { Number of } \\
\text { meals } 8 \text { y }\end{array}$ & & & & & & $\begin{array}{l}0.026 * * * \\
(0.009)\end{array}$ \\
\hline R-squared & 0.089 & 0.204 & 0.415 & 0.418 & 0.667 & 0.668 \\
\hline Observations & 5383 & 5383 & 5383 & 5383 & 5383 & 5383 \\
\hline
\end{tabular}

Notes: Standard errors clustered at the community the mother was residing in the calendar year she turned 10 years old are in parentheses. *** significant at $1 \%$, ** significant at $5 \%$, * significant at $10 \%$. The sample is restricted to children with non-missing or no extreme values in height-for-age Z-scores (greater than 6 in absolute value) in all rounds in India, Peru, and Vietnam. All specifications include mother's ethnicity, but estimates are not reported. Dummies for missing values in control variables, such as mother's education, father's education, wealth index, expenditure on child's health, dietary diversity, and the number of meals, are included in specifications containing these variables, but estimates are not reported. 
Table A10iii. OLS estimates of the impact of rainfall shocks in the mother's $13^{\text {th }}$ year of life on child nutritional status at age $12 \mathrm{y}$ including potential mediators in the India, Peru, and Vietnam pooled sample

\begin{tabular}{|c|c|c|c|c|c|c|c|c|}
\hline & \multicolumn{8}{|c|}{ HAZ 12 y } \\
\hline & (1) & (2) & (3) & (4) & (5) & (6) & (7) & (8) \\
\hline Rainfall & $-0.0025 * * *$ & $-0.0028 * * *$ & $-0.0019 * * *$ & $-0.0018 * * *$ & -0.0007 & -0.0007 & -0.0004 & -0.0004 \\
\hline $\begin{array}{l}\text { shock } \\
\text { mother's } 13 \text { y }\end{array}$ & $(0.0007)$ & $(0.0007)$ & $(0.0006)$ & $(0.0006)$ & $(0.0005)$ & $(0.0005)$ & $(0.0005)$ & $(0.0005)$ \\
\hline Male & 0.033 & 0.020 & $0.090 * * *$ & $0.091 * * *$ & $0.061 * * *$ & $0.059 * * *$ & $0.067 * * *$ & $0.066 * * *$ \\
\hline & $(0.027)$ & $(0.026)$ & $(0.023)$ & $(0.023)$ & $(0.021)$ & $(0.021)$ & $(0.019)$ & $(0.019)$ \\
\hline Child's age in & $-0.014 * * *$ & $-0.015^{* * *}$ & $0.018 * * *$ & $0.018 * * *$ & $-0.005^{*}$ & $-0.005^{*}$ & $-0.006^{* *}$ & $-0.006 * *$ \\
\hline Round 4 & $(0.005)$ & $(0.004)$ & $(0.004)$ & $(0.004)$ & $(0.003)$ & $(0.003)$ & $(0.002)$ & $(0.002)$ \\
\hline Mother's & & $0.027 * * *$ & $0.015 * * *$ & $0.014 * * *$ & 0.004 & 0.004 & -0.000 & -0.001 \\
\hline education & & $(0.005)$ & $(0.004)$ & $(0.004)$ & $(0.003)$ & $(0.003)$ & $(0.003)$ & $(0.003)$ \\
\hline Father's & & $0.020 * * *$ & $0.013 * * *$ & $0.011 * * *$ & $0.008 * *$ & $0.007 * *$ & $0.006 * *$ & $0.006 * *$ \\
\hline education & & $(0.004)$ & $(0.004)$ & $(0.004)$ & $(0.003)$ & $(0.003)$ & $(0.003)$ & $(0.003)$ \\
\hline Wealth index & & $0.872 * * *$ & $0.591 * * *$ & $0.550 * * *$ & $0.182 * *$ & $0.189 * * *$ & $0.125 * *$ & $0.134 * *$ \\
\hline $1 \mathrm{y}$ & & $(0.106)$ & $(0.088)$ & (0.089) & $(0.072)$ & $(0.071)$ & $(0.063)$ & $(0.062)$ \\
\hline Urban & & $0.182 * * *$ & $0.153 * * *$ & $0.139 * * *$ & 0.039 & 0.028 & -0.003 & -0.000 \\
\hline location $1 \mathrm{y}$ & & $(0.048)$ & $(0.039)$ & $(0.039)$ & $(0.030)$ & $(0.031)$ & $(0.027)$ & $(0.027)$ \\
\hline HAZ 1 y & & & $0.376 * * *$ & $0.372 * * *$ & $0.078 * * *$ & $0.079 * * *$ & $0.029 * * *$ & $0.029 * * *$ \\
\hline & & & $(0.014)$ & $(0.014)$ & $(0.013)$ & $(0.012)$ & $(0.010)$ & $(0.010)$ \\
\hline Expenditure & & & & 0.001 & 0.001 & 0.001 & $0.001 *$ & $0.001 *$ \\
\hline on child's & & & & $(0.001)$ & $(0.001)$ & $(0.001)$ & $(0.006)$ & $(0.006)$ \\
\hline health $5 \mathrm{y}$ & & & & & & & & \\
\hline Dietary & & & & $0.037 * * *$ & $0.017 * *$ & $0.014 * *$ & 0.010 & 0.009 \\
\hline diversity $5 \mathrm{y}$ & & & & $(0.009)$ & $(0.007)$ & $(0.007)$ & $(0.006)$ & $(0.006)$ \\
\hline Number of & & & & -0.003 & 0.007 & 0.006 & 0.005 & 0.005 \\
\hline meals $5 \mathrm{y}$ & & & & $(0.013)$ & $(0.010)$ & $(0.010)$ & (0.009) & $(0.009)$ \\
\hline HAZ 5 y & & & & & $0.677 * * *$ & $0.676 * * *$ & $0.311 * * *$ & $0.310 * * *$ \\
\hline & & & & & $(0.022)$ & $(0.022)$ & $(0.031)$ & $(0.031)$ \\
\hline Expenditure & & & & & & 0.001 & 0.001 & 0.001 \\
\hline on child's & & & & & & $(0.001)$ & $(0.001)$ & $(0.001)$ \\
\hline health $8 \mathrm{y}$ & & & & & & & & \\
\hline Dietary & & & & & & 0.005 & 0.004 & 0.003 \\
\hline diversity $8 \mathrm{y}$ & & & & & & $(0.006)$ & $(0.005)$ & $(0.005)$ \\
\hline Number of & & & & & & -0.002 & 0.012 & 0.012 \\
\hline meals 8 y & & & & & & $(0.012)$ & $(0.010)$ & $(0.010)$ \\
\hline HAZ 8 y & & & & & & & $0.528 * * *$ & $0.527 * * *$ \\
\hline & & & & & & & $(0.036)$ & $(0.036)$ \\
\hline Expenditure & & & & & & & & 0.001 \\
\hline on child's & & & & & & & & $(0.001)$ \\
\hline health $12 \mathrm{y}$ & & & & & & & & \\
\hline Dietary & & & & & & & & $0.009 *$ \\
\hline diversity 12 y & & & & & & & & $(0.005)$ \\
\hline Number of & & & & & & & & -0.013 \\
\hline meals $12 \mathrm{y}$ & & & & & & & & (0.009) \\
\hline R-squared & 0.105 & 0.212 & 0.384 & 0.387 & 0.603 & 0.604 & 0.687 & 0.688 \\
\hline Observations & 5383 & 5383 & 5383 & 5383 & 5383 & 5383 & 5383 & 5383 \\
\hline
\end{tabular}

Notes: Standard errors clustered at the community the mother was residing in the calendar year she turned 10 years old are in parentheses. $* * *$ significant at $1 \%$, ** significant at $5 \%$, * significant at $10 \%$. The sample is restricted to children with non-missing or no extreme values in height-for-age Z-scores (greater than 6 in absolute value) in all rounds in India, Peru, and Vietnam. All specifications include mother's ethnicity, but estimates are not reported. Dummies for missing values in control variables, such as mother's education, father's education, 
wealth index, expenditure on child's health, dietary diversity, and the number of meals, are included in specifications containing these variables, but estimates are not reported. 
Table A10iv. OLS estimates of the impact of rainfall shocks in the mother's $13^{\text {th }}$ year of life on child nutritional status at age $15 \mathrm{y}$ including potential mediators in the India, Peru, and Vietnam pooled sample

\begin{tabular}{|c|c|c|c|c|c|c|c|c|c|c|}
\hline & \multicolumn{10}{|c|}{ HAZ 15 y } \\
\hline & (1) & (2) & (3) & (4) & (5) & (6) & (7) & $(8)$ & $(9)$ & $(10)$ \\
\hline $\begin{array}{l}\text { Rainfall } \\
\text { shock } \\
\text { mother's } 13 \text { y }\end{array}$ & $\begin{array}{l}-0.0021^{* * *} \\
(0.0006)\end{array}$ & $\begin{array}{c}-0.0023^{* * *} \\
(0.0005)\end{array}$ & $\begin{array}{c}-0.0015 * * * \\
(0.0005)\end{array}$ & $\begin{array}{l}-0.0015 * * * \\
(0.0005)\end{array}$ & $\begin{array}{l}-0.0007 \\
(0.0004)\end{array}$ & $\begin{array}{l}-0.0007 \\
(0.0004)\end{array}$ & $\begin{array}{l}-0.0005 \\
(0.0004)\end{array}$ & $\begin{array}{l}-0.0005 \\
(0.0004)\end{array}$ & $\begin{array}{l}-0.0003 \\
(0.0004)\end{array}$ & $\begin{array}{l}-0.0003 \\
(0.0004)\end{array}$ \\
\hline Male & $\begin{array}{l}0.109 * * * \\
(0.028)\end{array}$ & $\begin{array}{l}0.102 * * * \\
(0.028)\end{array}$ & $\begin{array}{l}0.161 * * * \\
(0.025)\end{array}$ & $\begin{array}{l}0.163 * * * \\
(0.025)\end{array}$ & $\begin{array}{l}0.140 * * * \\
(0.020)\end{array}$ & $\begin{array}{l}0.138 * * * \\
(0.020)\end{array}$ & $\begin{array}{l}0.144 * * * \\
(0.019)\end{array}$ & $\begin{array}{l}0.143 * * * \\
(0.019)\end{array}$ & $\begin{array}{l}0.121 * * * \\
(0.020)\end{array}$ & $\begin{array}{l}0.122 * * * \\
(0.020)\end{array}$ \\
\hline $\begin{array}{l}\text { Child's age in } \\
\text { Round } 5\end{array}$ & $\begin{array}{l}-0.007 * \\
(0.004)\end{array}$ & $\begin{array}{l}-0.007 * * \\
(0.004)\end{array}$ & $\begin{array}{l}0.021 * * * \\
(0.004)\end{array}$ & $\begin{array}{l}0.021 * * * \\
(0.003)\end{array}$ & $\begin{array}{c}0.001 \\
(0.003)\end{array}$ & $\begin{array}{c}0.001 \\
(0.003)\end{array}$ & $\begin{array}{c}0.000 \\
(0.003)\end{array}$ & $\begin{array}{l}-0.000 \\
(0.003)\end{array}$ & $\begin{array}{c}0.002 \\
(0.002)\end{array}$ & $\begin{array}{c}0.002 \\
(0.002)\end{array}$ \\
\hline $\begin{array}{l}\text { Mother's } \\
\text { education }\end{array}$ & & $\begin{array}{l}0.018^{* * * *} \\
(0.004)\end{array}$ & $\begin{array}{l}0.008^{* *} \\
(0.004)\end{array}$ & $\begin{array}{l}0.007 * * \\
(0.004)\end{array}$ & $\begin{array}{l}-0.000 \\
(0.003)\end{array}$ & $\begin{array}{l}-0.000 \\
(0.003)\end{array}$ & $\begin{array}{l}-0.004 \\
(0.003)\end{array}$ & $\begin{array}{l}-0.004 \\
(0.003)\end{array}$ & $\begin{array}{l}-0.004 \\
(0.003)\end{array}$ & $\begin{array}{l}-0.004 \\
(0.003)\end{array}$ \\
\hline $\begin{array}{l}\text { Father's } \\
\text { education }\end{array}$ & & $\begin{array}{l}0.011 * * * \\
(0.004)\end{array}$ & $\begin{array}{c}0.005 \\
(0.003)\end{array}$ & $\begin{array}{c}0.005 \\
(0.003)\end{array}$ & $\begin{array}{c}0.002 \\
(0.003)\end{array}$ & $\begin{array}{c}0.001 \\
(0.003)\end{array}$ & $\begin{array}{c}0.001 \\
(0.003)\end{array}$ & $\begin{array}{c}0.001 \\
(0.003)\end{array}$ & $\begin{array}{c}-0.001 \\
(0.002)\end{array}$ & $\begin{array}{l}-0.001 \\
(0.002)\end{array}$ \\
\hline $\begin{array}{l}\text { Wealth index } \\
1 \mathrm{y}\end{array}$ & & $\begin{array}{l}0.464 * * * \\
(0.091)\end{array}$ & $\begin{array}{l}0.219 * * * \\
(0.076)\end{array}$ & $\begin{array}{l}0.207 * * * \\
(0.078)\end{array}$ & $\begin{array}{l}-0.074 \\
(0.065)\end{array}$ & $\begin{array}{l}-0.071 \\
(0.064)\end{array}$ & $\begin{array}{l}-0.120 * * \\
(0.059)\end{array}$ & $\begin{array}{l}-0.112 * \\
(0.059)\end{array}$ & $\begin{array}{l}-0.158 * * * \\
(0.054)\end{array}$ & $\begin{array}{l}-0.153 * * * \\
(0.054)\end{array}$ \\
\hline $\begin{array}{l}\text { Urban } \\
\text { location } 1 \mathrm{y}\end{array}$ & & $\begin{array}{l}0.083 * * \\
(0.039)\end{array}$ & $\begin{array}{c}0.060 * \\
(0.033)\end{array}$ & $\begin{array}{c}0.056^{*} \\
(0.033)\end{array}$ & $\begin{array}{l}-0.023 \\
(0.029)\end{array}$ & $\begin{array}{l}-0.029 \\
(0.029)\end{array}$ & $\begin{array}{l}-0.053^{*} \\
(0.028)\end{array}$ & $\begin{array}{c}-0.051 * \\
(0.028)\end{array}$ & $\begin{array}{l}-0.051^{*} \\
(0.026)\end{array}$ & $\begin{array}{l}-0.052 * * \\
(0.026)\end{array}$ \\
\hline HAZ 1 y & & & $\begin{array}{l}0.322 * * * \\
(0.012)\end{array}$ & $\begin{array}{l}0.321 * * * \\
(0.012)\end{array}$ & $\begin{array}{l}0.091 * * * \\
(0.012)\end{array}$ & $\begin{array}{l}0.092 * * * \\
(0.012)\end{array}$ & $\begin{array}{l}0.053 * * * \\
(0.010)\end{array}$ & $\begin{array}{l}0.053 * * * \\
(0.010)\end{array}$ & $\begin{array}{l}0.043 * * * \\
(0.009)\end{array}$ & $\begin{array}{l}0.042 * * * \\
(0.009)\end{array}$ \\
\hline $\begin{array}{l}\text { Expenditure } \\
\text { on child's } \\
\text { health } 5 \mathrm{y}\end{array}$ & & & & $\begin{array}{c}0.001 \\
(0.001)\end{array}$ & $\begin{array}{c}0.001 * \\
(0.006)\end{array}$ & $\begin{array}{c}0.001 * \\
(0.006)\end{array}$ & $\begin{array}{l}0.001 * * \\
(0.006)\end{array}$ & $\begin{array}{c}0.001 * \\
(0.006)\end{array}$ & $\begin{array}{c}0.001^{*} \\
(0.006)\end{array}$ & $\begin{array}{c}0.001 \\
(0.001)\end{array}$ \\
\hline $\begin{array}{l}\text { Dietary } \\
\text { diversity } 5 \text { y }\end{array}$ & & & & $\begin{array}{l}0.021 * * * \\
(0.007)\end{array}$ & $\begin{array}{c}0.006 \\
(0.006)\end{array}$ & $\begin{array}{c}0.007 \\
(0.007)\end{array}$ & $\begin{array}{c}0.003 \\
(0.006)\end{array}$ & $\begin{array}{c}0.002 \\
(0.006)\end{array}$ & $\begin{array}{l}-0.001 \\
(0.005)\end{array}$ & $\begin{array}{l}-0.001 \\
(0.005)\end{array}$ \\
\hline $\begin{array}{l}\text { Number of } \\
\text { meals } 5 \text { y }\end{array}$ & & & & $\begin{array}{l}-0.012 \\
(0.012)\end{array}$ & $\begin{array}{l}-0.004 \\
(0.010)\end{array}$ & $\begin{array}{l}-0.003 \\
(0.010)\end{array}$ & $\begin{array}{l}-0.004 \\
(0.009)\end{array}$ & $\begin{array}{l}-0.004 \\
(0.009)\end{array}$ & $\begin{array}{l}-0.005 \\
(0.008)\end{array}$ & $\begin{array}{l}-0.006 \\
(0.008)\end{array}$ \\
\hline HAZ 5 y & & & & & $\begin{array}{l}0.526 * * * \\
(0.018)\end{array}$ & $\begin{array}{l}0.526^{* * * *} \\
(0.018)\end{array}$ & $\begin{array}{l}0.242^{* * * *} \\
(0.026)\end{array}$ & $\begin{array}{l}0.242 * * * \\
(0.026)\end{array}$ & $\begin{array}{l}0.136^{* * * *} \\
(0.020)\end{array}$ & $\begin{array}{l}0.138 * * * \\
(0.020)\end{array}$ \\
\hline $\begin{array}{l}\text { Expenditure } \\
\text { on child's } \\
\text { health } 8 \mathrm{y}\end{array}$ & & & & & & $\begin{array}{c}0.001 \\
(0.001)\end{array}$ & $\begin{array}{c}0.001 \\
(0.001)\end{array}$ & $\begin{array}{c}0.001 \\
(0.001)\end{array}$ & $\begin{array}{c}0.001 \\
(0.001)\end{array}$ & $\begin{array}{c}0.001 \\
(0.001)\end{array}$ \\
\hline $\begin{array}{l}\text { Dietary } \\
\text { diversity } 8 \mathrm{y}\end{array}$ & & & & & & $\begin{array}{l}-0.002 \\
(0.006)\end{array}$ & $\begin{array}{c}-0.002 \\
(0.005)\end{array}$ & $\begin{array}{l}-0.003 \\
(0.005)\end{array}$ & $\begin{array}{l}-0.004 \\
(0.005)\end{array}$ & $\begin{array}{l}-0.005 \\
(0.005)\end{array}$ \\
\hline
\end{tabular}




\begin{tabular}{|c|c|c|c|c|c|c|c|c|c|c|}
\hline $\begin{array}{l}\text { Number of } \\
\text { meals } 8 \text { y }\end{array}$ & & & & & & $\begin{array}{l}-0.014 \\
(0.011)\end{array}$ & $\begin{array}{l}-0.003 \\
(0.010)\end{array}$ & $\begin{array}{l}-0.003 \\
(0.010)\end{array}$ & $\begin{array}{l}-0.007 \\
(0.009)\end{array}$ & $\begin{array}{l}-0.007 \\
(0.009)\end{array}$ \\
\hline HAZ 8 y & & & & & & & $\begin{array}{l}0.410^{* * *} \\
(0.031)\end{array}$ & $\begin{array}{l}0.408 * * * \\
(0.031)\end{array}$ & $\begin{array}{l}0.229 * * * \\
(0.024)\end{array}$ & $\begin{array}{l}0.229 * * * \\
(0.024)\end{array}$ \\
\hline $\begin{array}{l}\text { Expenditure } \\
\text { on child's } \\
\text { health } 12 \mathrm{y}\end{array}$ & & & & & & & & $\begin{array}{c}0.001 \\
(0.001)\end{array}$ & $\begin{array}{c}0.001 \\
(0.001)\end{array}$ & $\begin{array}{c}0.001 \\
(0.001)\end{array}$ \\
\hline $\begin{array}{l}\text { Dietary } \\
\text { diversity } 12 \mathrm{y}\end{array}$ & & & & & & & & $\begin{array}{c}0.008 \\
(0.005)\end{array}$ & $\begin{array}{c}0.005 \\
(0.005)\end{array}$ & $\begin{array}{c}0.005 \\
(0.005)\end{array}$ \\
\hline $\begin{array}{l}\text { Number of } \\
\text { meals } 12 \text { y }\end{array}$ & & & & & & & & $\begin{array}{l}-0.009 \\
(0.008)\end{array}$ & $\begin{array}{l}-0.005 \\
(0.008)\end{array}$ & $\begin{array}{l}-0.005 \\
(0.008)\end{array}$ \\
\hline HAZ 12 y & & & & & & & & & $\begin{array}{l}0.341 * * * \\
(0.019)\end{array}$ & $\begin{array}{l}0.340 * * * \\
(0.019)\end{array}$ \\
\hline $\begin{array}{l}\text { Expenditure } \\
\text { on child's } \\
\text { health } 15 \mathrm{y}\end{array}$ & & & & & & & & & & $\begin{array}{l}0.001 * * \\
(0.005)\end{array}$ \\
\hline $\begin{array}{l}\text { Dietary } \\
\text { diversity } 15 \mathrm{y}\end{array}$ & & & & & & & & & & $\begin{array}{l}-0.003 \\
(0.004)\end{array}$ \\
\hline $\begin{array}{l}\text { Number of } \\
\text { meals } 15 \mathrm{y}\end{array}$ & & & & & & & & & & $\begin{array}{c}0.010 \\
(0.008)\end{array}$ \\
\hline R-squared & 0.095 & 0.143 & 0.321 & 0.323 & 0.506 & 0.507 & 0.578 & 0.579 & 0.630 & 0.630 \\
\hline Observations & 5383 & 5383 & 5383 & 5383 & 5383 & 5383 & 5383 & 5383 & 5383 & 5383 \\
\hline
\end{tabular}

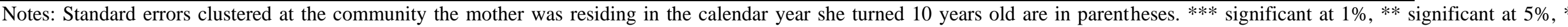

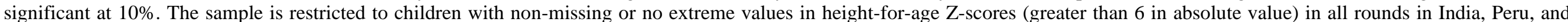

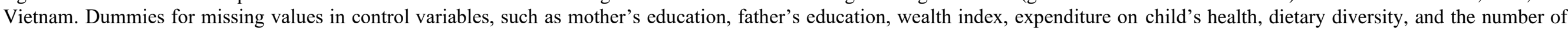
meals, are included in specifications containing these variables, but estimates are not reported. 